\title{
МИНЕРАЛОГИЯ, КРИСТАЛЛОГРАФИЯ
}

УДК $56+(470.55 / .58)$

\section{Минералого-геохимические особенности пещерной фоссилизации ископаемых костей на примере пещеры Иманай (Южный Урал)} \author{
В.И. Силаев ${ }^{\mathrm{a}}$, М.Н. Паршукова ${ }^{\mathrm{b}}$, Д.О. Гимранов ${ }^{\mathrm{c}}$, В.Н. Филиппов ${ }^{\mathrm{a}}$,
} Д.В. Киселёва ${ }^{d}$, И.В. Смолева ${ }^{a}$ Е.М. Тропников ${ }^{a}$, А.Ф. Хазов ${ }^{a}$

${ }^{a}$ Институт геологии Коми НЦ УрО РАН

167982, Сыктывкар, ул. Первомайская, 54. E-mail: silaev@geo.komisc.ru

${ }^{\mathrm{b}}$ Сыктывкарский государственный университет

167000, Сыктывкар, Октябрьский пр., 55

'Институт экологии растений и животных УрО РАН

620144, Екатеринбург, ул. 8 Марта, 202

${ }^{\mathrm{d}}$ Институт геологии и геохимии УрО РАН

620016, Екатеринбург, ул. Акад. Вонсовского, 15

(Статья поступила в редакиию 2 октября 2020 г.)

Впервые получены результаты комплексных минералого-геохимических исследований ископаемых костей плейстоценовых млекопитающих из пещеры Иманай (Южный Урал) с использованием оптической и сканирующей электронной микроскопии, статистического объемометрического метода определения нанопористости, термического, рентгеноструктурного и рентгено-флюоресцентного анализов, газовой хроматографии, ИК, КР и РЛ спектроскопии, ИСП МС, изотопной масс-спектрометрии. Цель исследований - получение экспериментальных данных о характере и степени фоссилизации костных остатков в условиях пещер, оценка возможностей палеоэкологических реконструкций по пещерным ископаемым костям. Обсуждаются данные о микростроении костных останков, нанопористости, химическом составе и концентрации микроэлементов, рентгеноструктурных и термических свойствах, изотопном составе минеральной и органической компонент в костях. Согласно полученным данным, фоссилизация костных остатков в условиях пещер принципиально отличается на всех уровнях строения и состава ископаемых костей от таковой во внепещерных обстановках. В частности, пещерные кости отличаются интенсивной эпигенетической кальцитизацией, в 3-5 раз большим содержанием $\mathrm{CO}_{2}$ и аномально высокими значениями атомного отношения $\mathrm{Ca} / \mathrm{P}$, но многократно уступают по содержанию иллювиированных минеральных загрязнений, обогащению микроэлементами вмещающей геологической среды, содержанию $\mathrm{C}_{\text {орг }}$ и коллагена. По изотопному составу углерода и кислорода в биоапатите пещерный костный детрит является аномально тяжелым, сближаясь с изотопным составом углерода и кислорода в морских известняках. Приведены некоторые палеоэкологические реконструкции, включая диету пещерных животных, рассмотрены доказательства обитания в пещере Иманай поздних неандертальцев.

Ключевые слова: неоплейстоцен, Южный Урал, пещера Иманай, пещерныле львы и медведи, минералогогеохимические исследования, особенности пещерной фоссилизации ископаемых костей, палеоэкологические реконструкиии, поздние неандертальцы.

DOI: $10.17072 /$ psu.geol.19.4.323

В настоящее время происходит методическая интервенция в любые природные объекты, где минералогические методы позволяют получить новую полезную информацию. Россия более ста лет является лидером органоминералогических исследований.

Академик Н. П. Юшкин

\section{Введение}

В современной отечественной палеонтологии при всей ее тотальной аналитической запущенности (Силаев и др., 2016) есть все- таки область, выделяющаяся даже на таком фоне. И эта область - пещерные ориктоценозы, уровень исследований которых практически не изменился с 18-19 вв., т. е. со вре-

(С) Силаев В.И., Паршукова М.Н., Гимранов Д.О., Филиппов В.Н., Киселёва Д.В., Смолева И.В., Тропников Е.М., Хазов А.Ф., 2020 
мени первых собирателей ископаемых костей в пещерах (Чикишев, 1973; Горбунова, 1988; Дублинский, Козлова, 1994; Оводов, 2009), на территории, например, Западной Сибири (Ф.И. Страленберг ${ }^{1}$, И.Г. Гмелин, И. Пестов, И.С. Боголюбский), Алтае-Саянской области (А.Г. Влангели ${ }^{2}$, И.Ф. Брандт, П.С. Паллас, Ф.Б. Геблер, А.И. Кулибин $\left.{ }^{3}\right)$, Хакасии (П. С. Паллас), Грузии (Ф. Дюбуа де Монпере ${ }^{4}$ ), Крыма (К. С. Мережковский ${ }^{5}$. Лишь открытие феноменальной костеносности элювиальных грунтов в пещере Иманай на Южном Урале (Яковлев и др., 2016; Гимранов и др., 2016; Паршукова, 2016; Гимранов и др., 2017; Гимранов и др., 2018; Gimranov et al., 2018) потребовало кардинального пересмотра палеонтолого-археологической традиции поверхностного описания и зоологической систематизации пещерного костного детрита в пользу экспериментального естествознания. Тем более что для этого уже существует вполне адекватная научная база (Смирнов и др., 2009; Вотяков и др., 2009; Силаев и др., 2015).

Следует подчеркнуть, что в настоящее время реализация программы экспериментальных научных исследований костных остатков пещерных животных весьма актуализирована открытием в 2018 г. в Крыму уникальной пещеры Таврида с громадным комплексом костного детрита, датирующегося в диапазоне от миоцена до неоплейстоцена. Очевидно, что без надежных знаний об особенностях пещерной фоссилизации ископаемых костей полноценное изучение ориктоценоза такой пещеры просто невозможно.

\section{Общие сведения}

Карстовая пещера Иманай была обнаружена в 2010 г. госинспектором Национального парка Башкирия Р. Р. Альмухаметовым в борту одноименного лога в 7 км к северовостоку от пос. Нугуш (рис. 1, а). Пещера

\footnotetext{
${ }^{1}$ Первоописатель сибирских пещер.

${ }^{2}$ Российский географ, геолог и дипломат.

${ }^{3}$ Сын легендарного механика И. П. Кулибина, горный инженер.

${ }^{4}$ Швейцарский археолог и натуралист, ученик энциклопедиста А. фон Гумбольда.

5 Ботаник, зоолог, археолог. Провел раскопки 34 пещер в Крыму, обнаружив стоянки неандертальцев, включая стоянку Волчий грот.
}

длиной до 100 м с гротом размером $5 \times 6$ м располагается в сероцветных доломитизированных известняках кунгурского яруса нижней перми. У входа в пещеру и внутри нее обнаружен редкий по сложности ориктоценоз плейстоценовых млекопитающих (табл. 1), центральное место в котором занимают костные остатки пещерных львов и медведей. Датирование этих костей было осуществлено в ЦКП «Лаборатория радиоуглеродного датирования и электронной микроскопии» Института географии РАН.

Таблица 1. Иманай-пещерный ориктоиеноз плейстоценового возраста (Gimranov, Kosintsev, 2020)

\begin{tabular}{|l|c|}
\hline Виды ископаемой фауны & $\begin{array}{c}\text { Число иденти- } \\
\text { фицирован- } \\
\text { ных образцов }\end{array}$ \\
\hline Canis sp. & 5 \\
\hline Marmota sp. & 13 \\
\hline Castor fiber (Linnaeus, 1758) & 2 \\
\hline Pantera ex. gr. Fossilis-spelaea & $\mathbf{5 3 6}$ \\
\hline Cuon sp. & 2 \\
\hline Canis lupus (Linnaeus, 1758) & 42 \\
\hline Canis sp. & 1 \\
\hline Vulpes lagopus (Linnaeus, 1758) & 2 \\
\hline V. vulpes (Linnaeus, 1758) & 3 \\
\hline Vulpes sp. & 17 \\
\hline Meles sp. & 2 \\
\hline Gulo gulo (Linnaeus, 1758) & 24 \\
\hline Mustela ermine (Linnaeus, 1758) & 1 \\
\hline M. ex.gr. putorius-eversmanii & 6 \\
\hline Mustelidae gen. indet. & 1 \\
\hline Ursus «savini» (Andrews, 1922) & $\mathbf{9 4 1 4}$ \\
\hline Ursus arctos (Linnaeus, 1758) & 16 \\
\hline Ursus thibetanus (Cuvier, 1823) & 3 \\
\hline $\begin{array}{l}\text { Mammunthus primigenius } \\
\text { (Blumenbach, 1799) }\end{array}$ & 2 \\
\hline Eguus ferus (Boddaert, 1785) & 4 \\
\hline Rhinocerotidae gen. indet & 2 \\
\hline Saiga tatarica (Linnaeus, 1766) & 22 \\
\hline Ovis ammon (Linnaeus, 1758) & 17 \\
\hline Gтого & $\mathbf{1 0 1 3 7}$ \\
\hline
\end{tabular}

Калиброванные значения возраста составили для львов $-34940 \pm 140$, а для медведей - $42410 \pm 260$ лет назад. Полученные датировки приходятся примерно на средину каргинского (средневалдайского) интерстадиала, а точнее, на разные периоды относительного похолодания в рамках этого времени более ранний (44-41 тыс. лет назад) для пе- 
щерных львов и более поздний (35-30 тыс. лет назад) для медведей.

Кроме костного детрита в пещерных отложениях археологами найдено множество каменных орудий мустьерской эпохи - среднего палеолита (Гимранов и др., 2016), приписываемых поздним неандертальцам, а также обнаружены очажные пятна, свидетельствующие о непосредственном обитании древних людей в пещере.

Изученный профиль костеносных элювиальных отложений в пещере Иманай имеет мощность около 1 м. Он почти нацело сложен гранулометрически весьма неоднородными грунтами серого цвета с буроватым или розоватым оттенками (рис. 1, б). В направлении сверху вниз профиль был подразделен на 12 горизонтов или (условно) слоев (рис. 1, в), гранулометрический состав которых определяется пятью фракциями: гравийной, песчаной грубозернистой, песчаной крупно-среднезернистой, песчаной мелко-тонкозернистой и алевропелитовой (глинистой). Обобщая полученные нами данные (Силаев и др., 2018), можно прийти к следующей литологической номенклатуре пещерного костеносного элювия.

Слой 1: гравий песчаный, отвечающий по литологическому составу доломитисто-известковому мергелю.

Слой 2: песок гравийный доломитистоизвестковый.

Слой 3: песок алевро-гравийный доломитистоизвестковый.

Слой 4: песок алевро-гравийный известководоломитовый.

Слой 5: песок алевро-гравийный, отвечающий по составу известковисто-доломито-вому глинистому мергелю.

Слой 6: песок алевро-гравийный доломитовоизвестковый.

Слой 7: песок алевро-гравийный некарбонатный. Слой 8: песок алевро-гравийный известковый.

Слой 9: песок алевро-гравийный известководоломитовый.

Слой 10: песок алевро-гравийный доломитистоизвестковый

Слой 11: песок гравийный доломитистоизвестковый.

Слой12: песок гравийный, отвечающий по составу доломитисто-известковому мергелю.

На треугольнике гранулометрического состава костеносных грунтов (рис. 2, а) пробы почти всех слоев элювиальных отложений в пещере Иманай попали в поле гравийных песков, за исключением образцов песчаного гравия в слое 1 и глинисто-гравийных песков в слое 9. Очевидно также, что основную массу в исследуемых грунтах составляют пески, широко варьирующиеся по гранулометрии от грубо- до мелко-тонкозернистых. Судя по композиции песчаных фракций, иманайские грунты являются микститовыми (рис. 2, б), т. е. совершенно несортированными, что указывает на их автохтонное (непереотложенное) происхождение.

Таким образом, костеносные грунты в пещере Иманай по гранулометрическому составу являются песчано-гравийными, гравийно-песчаными и глинисто-гравийно-песчаными. При этом в направлении сверху вниз по профилю отложений в интервале до слоя 10 включительно выявляется тенденция к переходу от более крупнообломочных (песчано-гравийных и гравийно-песчаных) осадков к несколько менее крупнообломочным (глинисто-гравийно-песчаным). В самых нижних слоях 11 и 12 пещерные отложения опять становятся гравийнопесчаными. Отсутствие признаков флюидальности, гранулометрической сортировки и механической обработки обломков свидетельствует об их именно элювиальном происхождении. При этом признаков существенных гидролитических изменений (химического выветривания) грунтов тоже не выявлено, что можно рассматривать как благоприятное обстоятельство для перспективных палеонтологических и палеозоологических поисков.

По химическому и минеральному составу элювиальные отложения в пещере являются фосфатно-карбонатно-силикатными. В силикатную компоненту входят кварц, альбит, диоктаэдрические гидрослюды и хлориты. Карбонатная компонента варьирует от известковой до известковисто-доломитовой, что комплементарно составу подвергнувшихся карстованию нижнепермских карбонатных пород. Присутствие фосфатного вещества в грунтах обусловлено, очевидно, дезинтеграцией костных остатков, их частичным растворением и переотложением растворенного фосфатного вещества. 


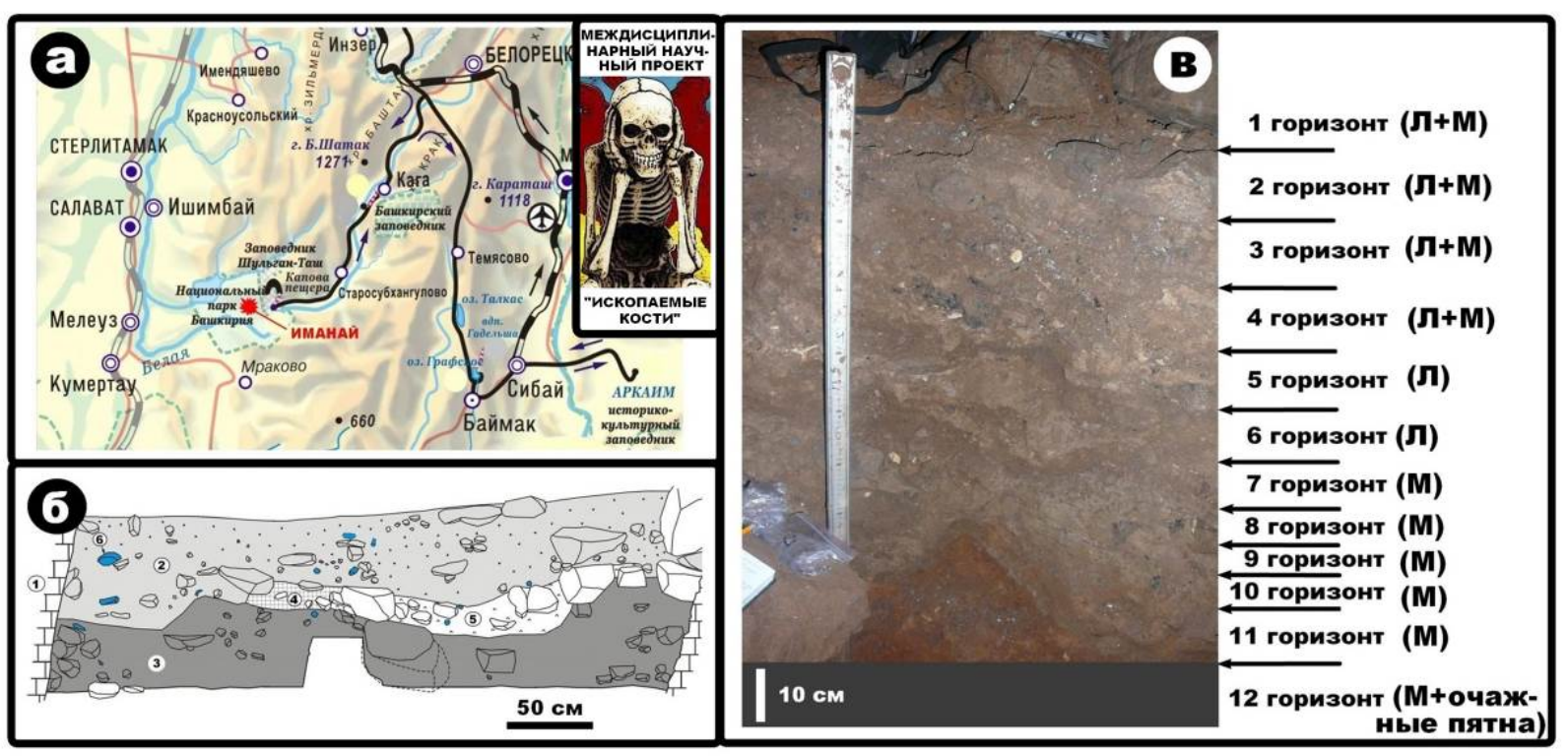

Рис. 1. Географическое положение пещееры Иманай (а), общий вид (б) и строение (в) выявленного в ней профиля костеносных элювиальных грунтов: 1- стенки карбонатной пещеры; 2-4 - грунты соответственно сероиветные, светло-бурые и серовато-коричневые; 5 - натеки карбонатного туфа; 6 - каменные артефакты, отнесенные к мустьерской эпохе (среднему палеолиту); Л и М-наличие костного детрита соответственно пещерных львов и медведей в слоях элювиальных грунтов

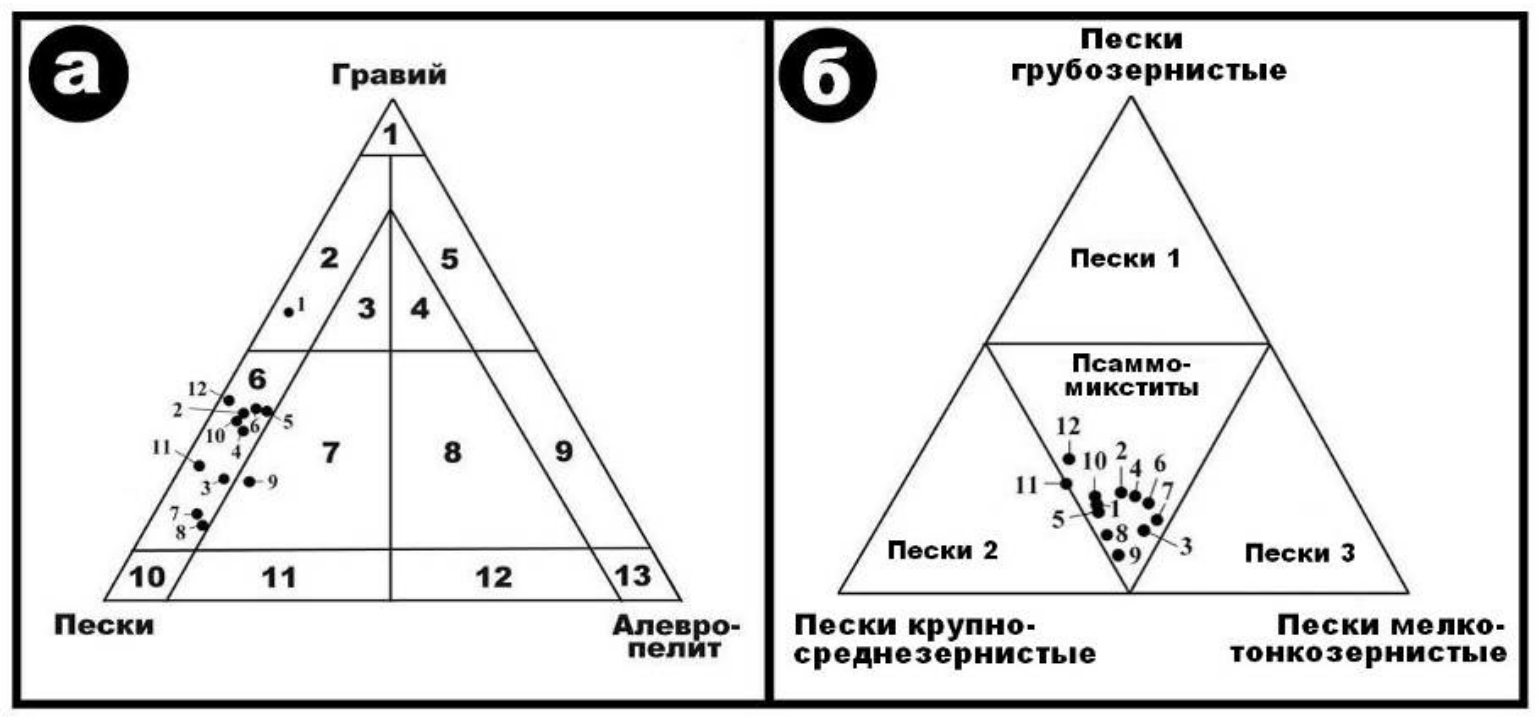

Рис. 2. Общая гранулометрическая характеристика костеносных элювиальных грунтов в пещере Иманай (а) и оценка гранулометрического состава их песчаной компоненты (б). а: 1- гравий; 2-5 гравий соответственно песчаный, глинисто-песчаный, песчано-глинистый и глинистый; 6, 7 - пески соответственно гравийные и глинисто-гравийные; 8, 9 - глины соответственно гравийно-песчаные и гравийные; 10 - пески; 11 - пески глинистые; 12 - глины песчаные; 13 - глины. б: пески преимущественно грубозернистые (1), крупно-среднезернистые (2), мелко-тонкозернистые (3); псаммомикститы - несортированная гранулометрическая смесь песков. Точками показаны составы исследованных образиов пещерных грунтов из слоев 1-12

Присутствие в грунтах тонкодисперсного костного материала подтверждается не только повышенным (до 0.33 мас. \%) в них содержанием $\mathrm{C}_{\text {орг }}$, но и результатами термического анализа. Таким образом, почти весь интервал костеносных элювиальных грунтов в пещере Иманай (выше 12 горизонта) образовался уже после максимума последнего оледенения (LGM), т. е. в период после 15 тыс. лет назад (Кольфсхотен и др., 2008). 


\section{Объекты и методы исследований}

Важнейшее место в иманайском пещерном ориктоценозе занимают костные остатки пещерных медведя и льва. В обоих случаях мы имеем дело с особенными феноменами малым пещерным медведем, обитавшим большей частью, как считается, вне пещер, и так называемым гигантским пещерным львом (Сотникова, Гимранов, 2017). Последний факт доказывается анализом размеров зубов. Зубы иманайских львов - и самцов, и самок (рис. 3, а) - значительно превышают таковые у обычных пещерных львов (Barucka, 2008) и тем более у современных львов (рис. 3, б). При этом обнаруживается, что у современных и ископаемых пещерных львов половой диморфизм в интегральных характеристиках зубов выражается совершенно по-разному. Если у современных львов самцы характеризуются более крупными (примерно на 20-25 \%) и при этом более удлиненными (острыми) зубами, то у пещерных львов самцы отличались от самок, хотя и более крупными, но более «тупыми» зубами (рис. 3, в).

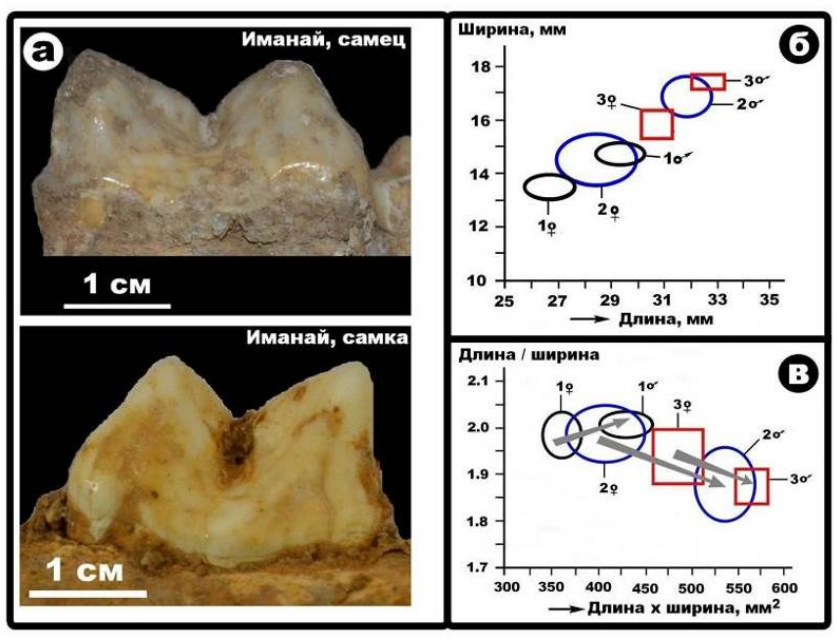

Рис. 3. Форма и размеры нижних хищзных (сагnassial) зубов иманайских пещерных львов (а) и графики полового диморфизма по зубам (б, в) для современных львов (1), для львов из пещеры Виешховска Гурна (2) и пещеры Иманай (3)

Таким образом, получается, что иманайские львы, судя по зубам, действительно отличались более крупными размерами, чем обычные Panthera (Leo) spelaea. Как известно, в период перехода от среднего к поздне- му плейстоцену в Европе появился Panthera (Leo) spelaea intermedius, промежуточный по размерам между архаичным Pantera (Leo) antrox и относительно мелким Panthera (Leo) spelaea (Argani et al., 2007; Сотникова, Кириллова, 2017). Не исключено, что именно эта промежуточная форма ископаемого пещерного льва, обозначенная в табл. 1 как Pantera ex. gr. Fossilis-spelaea, и обнаружена в пещере Иманай (рис. 4).

Непосредственными объектами наших исследований послужили две коллекции остеологически (анатомически) разнообразных костных остатков пещерных львов и медведей (табл. 2). Этот костный детрит не несет признаков механической обработки и варьирует по размерам в львиной и медвежьей группах образцов в сравнительно узких пределах.
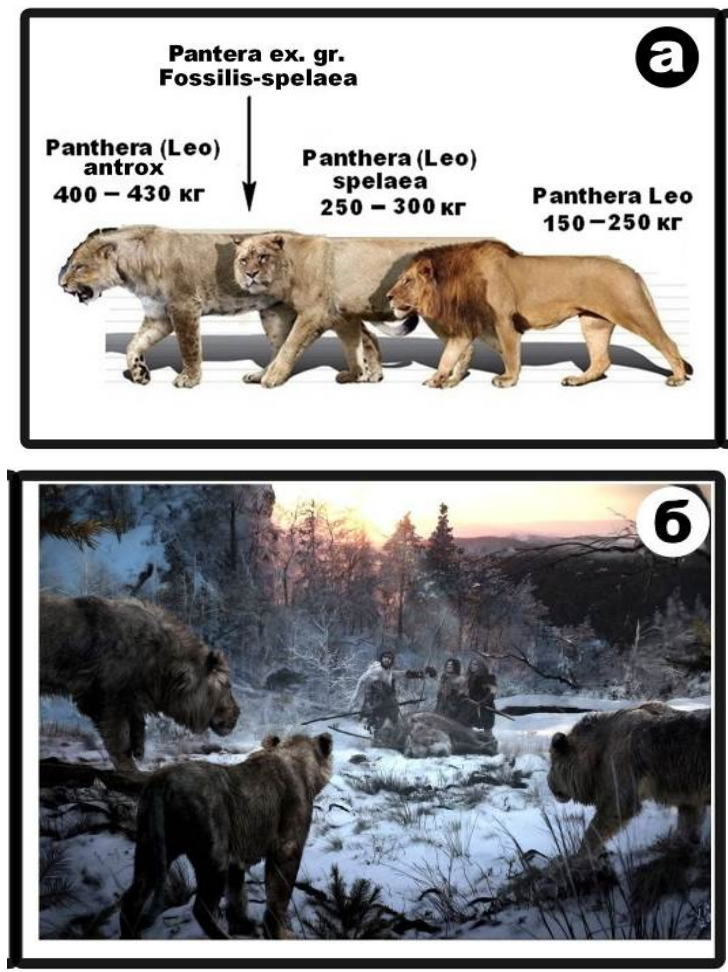

Рис. 4. Размеры пещерных и современных львов (a) на фоне иллюстрации Велизара Семионовски 6 «Недолгий триумф» вымышленного факта плейстоиеновой истории пещеры Иманай (б)

Наибольшим остеологическим разнообразием характеризуются костные остатки пещерного медведя, будучи представленные фрагментами черепа, нижней челюсти, ат-

\footnotetext{
${ }^{6}$ Очень талантливый болгаро-американский зоолог, специализирующийся на научной и художественной иллюстрации вымерших млекопитающих и палеоландшафтов.
} 
ланта, бедренной кости, костей метаподия, фаланг конечностей, зубов и клыков (рис. 5), размеры которых составляют соответственно $(\mathrm{cм}):(11.4 \pm 3.7) \times(5.3 \pm 2.6) ; 17.7 \times 6 ;(4 \pm 1.9) \times$ $(2.3 \pm 1.7) ;(10.2 \pm 7.7) ;(3.35 \pm 0.7) \times(1.5 \pm 0.2) ;$ $(1.7 \pm 0.8) \times(1.2 \pm 0.5) ;(4.8 \pm 3) \times(1.8 \pm 0.9)$. Общая статистика размеров исследованных медвежьих костей определяется как $(5.1 \pm 4.2)$ $\times(2.5 \pm 2) \mathrm{cm}$.

Таблица 2. Исследованный костный детрит львов (1-15) и медведей (16-30)

\begin{tabular}{|c|c|c|c|}
\hline №n/II & № обр. & Остеология & Горизонт \\
\hline 1 & 622 & Позвонок & 2 \\
\hline 2 & 823 & $\lll$ & 4 \\
\hline 3 & 2847 & $\ll$ & 5 \\
\hline 4 & 492 & $\ll$ & 6 \\
\hline 5 & 2869 & 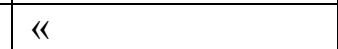 & $\ll$ \\
\hline 6 & 2803 & Ребро & 1 \\
\hline 7 & 2411 & « & 2 \\
\hline 8 & 2870 & $\ll$ & 6 \\
\hline 9 & 2871 & $\ll$ & $\ll$ \\
\hline 10 & 3111 & Сесамовидная кость & 1 \\
\hline 11 & 3112 & $\ll$ & $\ll$ \\
\hline 12 & 2987 & $\ll$ & 2 \\
\hline 13 & 3046 & 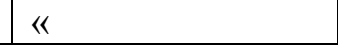 & 4 \\
\hline 14 & 2974 & Фаланга № 2 & 3 \\
\hline 15 & 2975 & Клык & $\ll$ \\
\hline 16 & $1 / 1$ & Фаланга & 1 \\
\hline 17 & $1 / 2$ & Череп & $\ll$ \\
\hline 18 & 2 & Метаподий & 2 \\
\hline 19 & $3 / 1$ & Атлант & 3 \\
\hline 20 & $3 / 2$ & Ребро & 4 \\
\hline 21 & $4 / 1 \mathrm{a}$ & Зубная эмаль & $\ll$ \\
\hline 22 & $4 / 16$ & Дентин & $\ll$ \\
\hline 23 & $4 / 2$ & Моляр нижний & $\ll$ \\
\hline 24 & 7 & Клык в грунте & 7 \\
\hline 25 & 8 & Бедро & 8 \\
\hline 26 & 9 & Фаланга & 9 \\
\hline 27 & $(10+11) / 1$ & Челюсть & $10+11$ \\
\hline 28 & $(10+11) / 2$ & Премоляр верхний & $\ll$ \\
\hline 29 & $12 \mathrm{M}$ & Метаподий & 12 \\
\hline 30 & $12 \phi$ & Фаланга & $\ll$ \\
\hline
\end{tabular}

К костным остаткам иманайского пещерного льва относятся позвонки, ребра, сесамовидная кость и клыки (рис. 6), размеры которых заметно превышают размеры костей пещерного медведя (см): $(10.3 \pm 6.2) \times(7.2 \pm$ $3.3) ;(9.2 \pm 3.7) \times(2.1 \pm 0.7) ;(30 \pm 13.4) \times(13.5 \pm$ $4.6) ; 13.7 \times 10$. Общая статистическая оценка размеров костного детрита пещерного льва $(14.9 \pm 10.4) \pm(6.8 \pm 5.5)$ см. В сечениях костей наблюдается достаточно хорошо сохранившееся внутреннее строение с контрастно различающимися компактным и губчатоячеистым типами костной ткани (рис. 7).

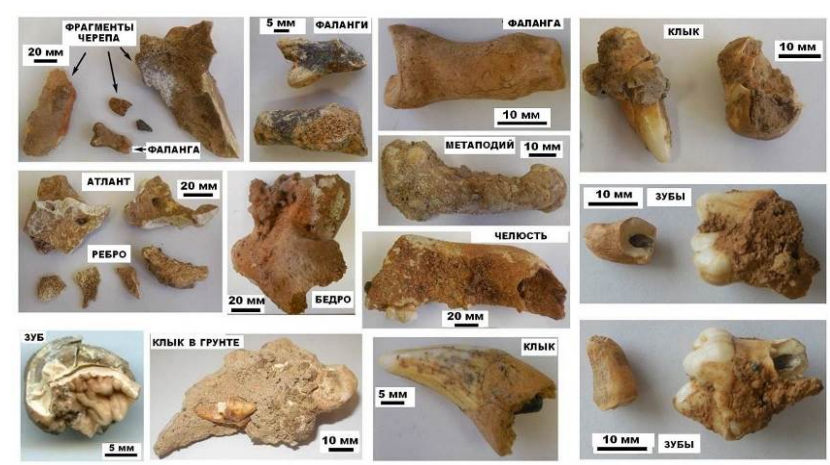

Рис. 5. Исследованные костные остатки иманайского пещерного медведя

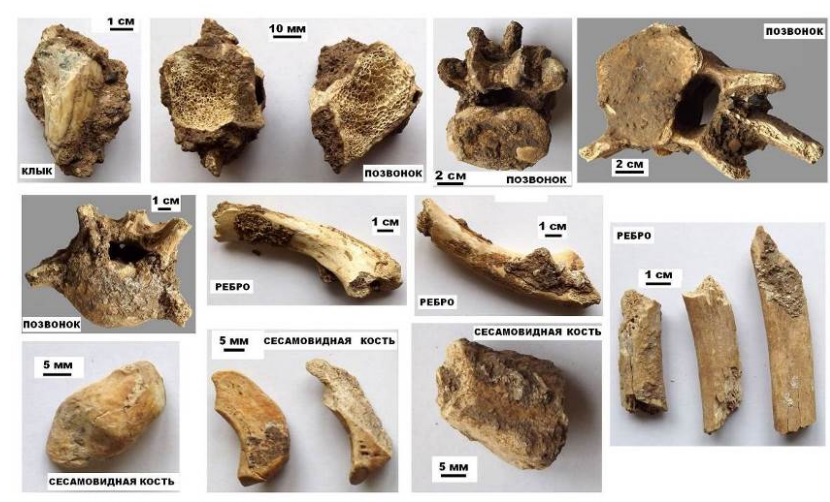

Рис. 6. Исследованные костные остатки иманайского пещерного льва

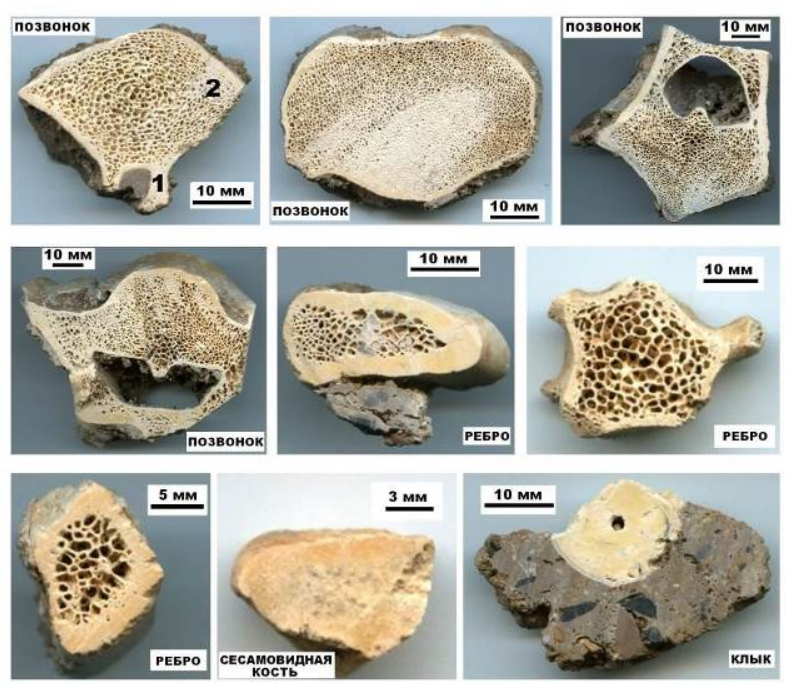

Рис. 7. Типичные сечения костей иманайского пещерного льва: 1, 2 - соответственно компактный и губчато-ячеистый типы костной ткани 
Таким образом, проведенные измерения и расчеты приводят к выводу о том, что костные остатки иманайских львов и медведей по размерам статистически сильно различаются: обломки скелетов львов в среднем почти в три раза крупнее, чем обломки скелетов медведей. Интересно, что примерно такое же различие обнаруживается и при отдельном сопоставлении клыков. Из всего этого следует, что причиной выявленных различий являются не только особенности фрагментизации скелетов, но, вероятно, и изначальные расхождения в массивности и, возможно, прочности костей.

Раскопки и палеозоологические исследования костного детрита финансировались за счет гранта Российского научного фонда (проект № 20-74-00041). В ходе исследований иманайских пещерных костей применялся широкий комплекс современных аналитических методов: гранулометрический анализ грунтов ситовым методом (в диапазоне от +2 до -0.06 мм); термический анализ (DTG-60A/60 AH, Shimazu); аналитическая химия (О. В. Кокшарова); определение содержания $\mathrm{C}_{\text {орг }}$ методом кулонометрического титрования (С. А. Забоева); рентгеновская дифрактометрия (Ю. С. Симакова, XRD6000); рентгенофлюоресцентный анализ (C. T. Неверов, XRD-1800, Shimazu); рамановская спектроскопия (Е.A. Васильев, Lab Ram800 Horiba, He-Ne лазер, 632.8 нм); рентгенолюминесцентная спектроскопия (Ю. В. Глухов, установка, состоящая из монохроматора AAS-1, рентгеновского аппарата УРС1.0 , блока электронной регистрации ФЭУ106 и ртутной лампы ДРК-120 ( $\lambda_{\text {возб }}=365$ нм); оптическая микроскопия (компьютеризированный комплекс OLYMPUS BX51); аналитическая растровая электронная микроскопия (JSM-6400 Jeol); определение нанопористости по кинетике адсорбции/десорбции азота (Nova 1200e, Quantachrome Instruments); определение coдержания микроэлементов методом ИСПMC (ELAN 9000 Perkin Elmer, Германия); элементный анализ костного коллагена методом газовой хроматографии (Е. А. Туманова; EA 1110 (CHNS-O), CE Instruments, Италия); инфракрасная спектроскопия (М. Ф. Самотолкова; ФТ-2 Инфралюм); анализ изотопного состава $\mathrm{C}, \mathrm{O}$ в биоапатите и $\mathrm{C}, \mathrm{N}$ в костном коллагене (проточный массспектрометр Delta V. Avantage и аналитический комплекс Thermo Fisher, Германия).

ИСП-МС анализы выполнены в ЦКП УрО РАН «Геоаналитик» при поддержке грантом РНФ № 16-17-10283, КР спектры получены в Санкт-Петербургском горном университете. Все остальные аналитические работы осуществлены в Институте геологии Коми НЦ УpO РАH.

\section{Микростроение и ультрапористость органоминерального костного композита}

Внутреннее строение костных остатков иманайских львов и медведей исследовалось методом оптической поляризационной микроскопии. Полученные результаты свидетельствуют в целом о значительной степени деградации биоапатита костей, но различной для пещерных медведей и львов. Исследованы фрагменты атланта, костей метаподия, черепа и фаланги пещерных медведей (рис. 8).

Атлант (шейный позвонок) - проанализирована плотная костная ткань, характеризующаяся минимальной степенью коллофанизации (аморфизации) биоапатита и умеренной сохранностью его волокнистости и остеон-структуры.

Размеры сечений остеонов варьируют в пределах $(269 \pm 69) \times(204 \pm 41)$ мкм, коэффициент их изометричности оценивается в $(0.78 \pm 0.15)$. Остеоциты почти не наблюдаются.

Meтаподий (кости конечностей) - плотная костная ткань с умеренной степенью коллофанизации биоапатита и сохранности волокнистости и остеон-структуры. Остеоциты не наблюдаются. Размеры сечений остеонов колеблются в пределах $(476 \pm 152)$ $\times(224 \pm 81)$ мкм, коэффициент изометричности составляет $(0.49 \pm 0.18)$.

Череn - плотная ткань со значительной степенью коллофанизации биоапатита и лишь фрагментарно сохранившейся остеонструктурой. Размер сечений остеонов изменяется в пределах $(448 \pm 103) \times(261 \pm 106)$ мкм, коэффициент изометричности сечений - (0.58 \pm 0.14$)$. Многие каналы заполнены микрокристаллическим карбонатом. 
Фаланги (пальцы конечностей) - наблюдается плотный и губчатый типы костной ткани с сильно коллофанизированным биоапатитом. В плотной ткани остеонструктура сильно затушевана и практически не наблюдается. В губчатой ткани трабекулы нарушены, размер ячей варьируется в пределах $(722 \pm 218) \times(389 \pm 77)$ мкм, коэффициент изометричности оценивается в $(0.59 \pm$ $0.25)$.

Оптикомикроскопическим методом были исследованы фрагменты ребер, позвонки, сесамовидные кости, фаланги и клыки пещерных львов (рис. 9).

Ребра - исследована плотная ткань, сложенная практически нацело коллофанизированным и потому оптически непрозрачным биоапатитом. Наблюдается теневая волокнистая текстура сильно измененной кости.

Позвонки - плотная и губчатая ткани. За редким исключением ткани сложены тотально коллофанизированным оптически непрозрачным биоапатитом. Тем не менее в плотной ткани улавливается теневая остеонструктура. Видимые размеры сечений остеонов колеблются в пределах $(389 \pm 154) \times$ $(243 \pm 102)$, коэффициент изометричности составляет $(0.66 \pm 0.17)$. В редких случаях в костной ткани позвонков наблюдаются участки, не затронутые коллофанизацией с хорошо сохранившейся первичной структурой. Губчатая ткань - плохо сохранившаяся, с сильно деградированными трабекулами, в ячеях наблюдается переотложенный карбонат.

Сесамовидная кость - плотная и губчатая костные ткани. Большинство образцов ткани сложены тотально коллофанизированным оптически непрозрачным биоапатитом. Остеон-структура едва различается, видимые размеры сечений остеонов оцениваются в $(291 \pm 50) \times(226 \pm 63)$ мкм, коэффициент изометричности $-(0.78 \pm 0.19)$. Кроме того, в плотной ткани наблюдаются каверны выщелачивания и микротрещины, инкрустированные микрокристаллическим карбонатом.

Размер каверн составляет $(291 \pm 176) \times$ $(143 \pm 90)$ мкм, коэффициент изометричности - $(0.54 \pm 0.23)$. Ячеи в губчатой ткани также минерализованы переотложенным карбонатом. В единичных случаях обнаружены фрагменты сесамовидной кости с хо- рошей сохранностью губчатой ткани, сложенной биоапатитом с незначительной степенью коллофанизации. В трабекулах наблюдается волокнистое строение, их толщина варьируется в пределах $(276 \pm 118)$ мкм. Ячеи - неминерализованные с размером $(468 \pm 157) \times(294 \pm 80)$ мкм, коэффициент изометричности составляет $(0.66 \pm 0.2)$.

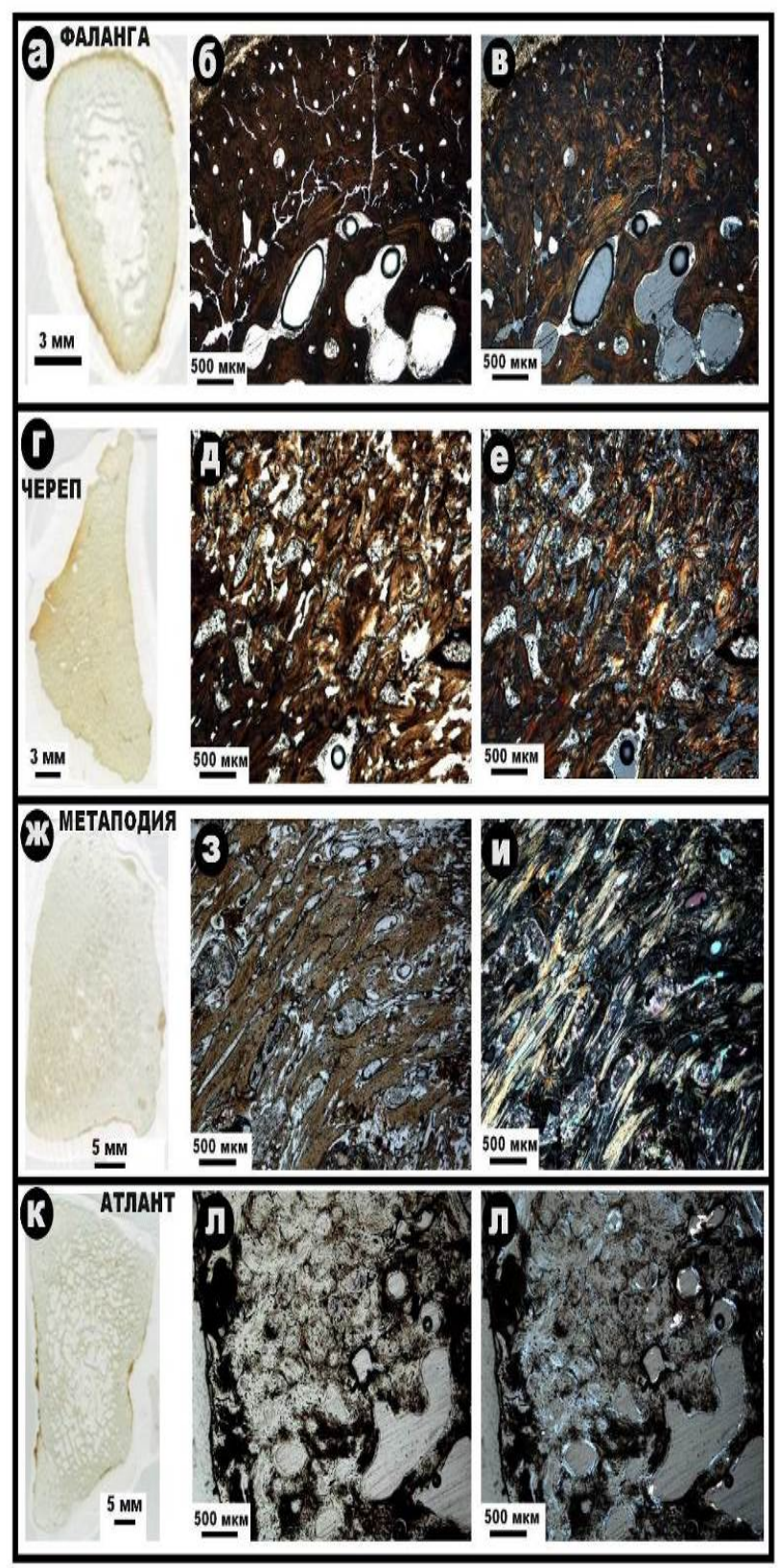

Рис. 8. Микростроение костного детрита иманайских пещерных медведей под оптическим микроскопом: а, г, ж, к-сканы шлифов; б, д, з, л-изображения в режиме параллельных николей; в, е, и, м-изображения в режиме скрещченных николей 
Фаланги - плотная и губчатая костные ткани с оптически непрозрачным нацело коллофанизированным биоапатитом. Остеон-структура проступает очень нечетко, видимый размер сечений остеонов колеблется в пределах $(341 \pm 172) \times(235 \pm 121)$ мкм, коэффициент изометричности - $(0.71 \pm 0.15)$. Трабекулы в губчатой ткани сильно деградированы, размер ячей составляет $(657 \pm 313) \times$ $(333 \pm 146)$ мкм, коэффициент изометричности $-(0.55 \pm 0.2)$.

Клькк - сложен нацело коллофанизированным биоапатитом, разбитым сетью тонких трещин. Разделение на дентин и эмаль не наблюдается.

Обобщение результатов оптикомикроскопических исследований приводит к следующему выводу. Иманайский костный детрит в целом обнаруживает степень вторичных изменений, значительно превышающую степень изменения близких по возрасту ископаемых костей животных, захороненных во внепещерных условиях, например, плейстоценовых лошадей на открытой П. Ю. Павловым западно-уральской стоянке Заозерье (Силаев и др., 2019).

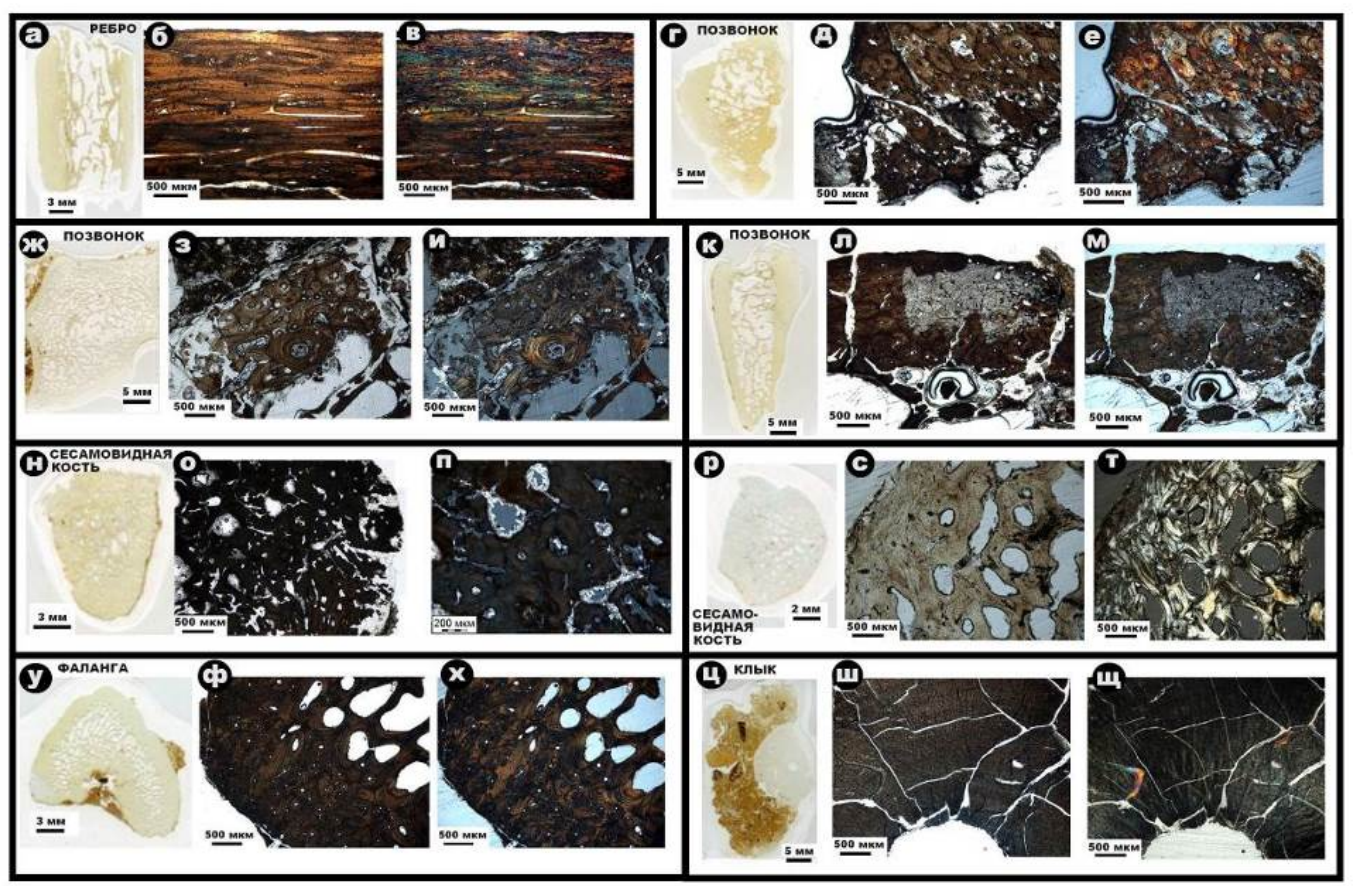

Рис. 9. Микростроение костного детрита иманайских пещерных львов под оптическим микроско-

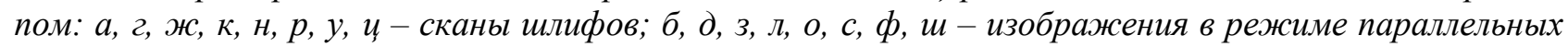

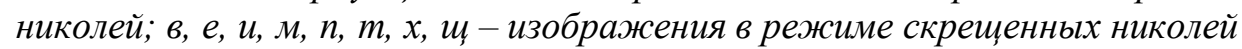

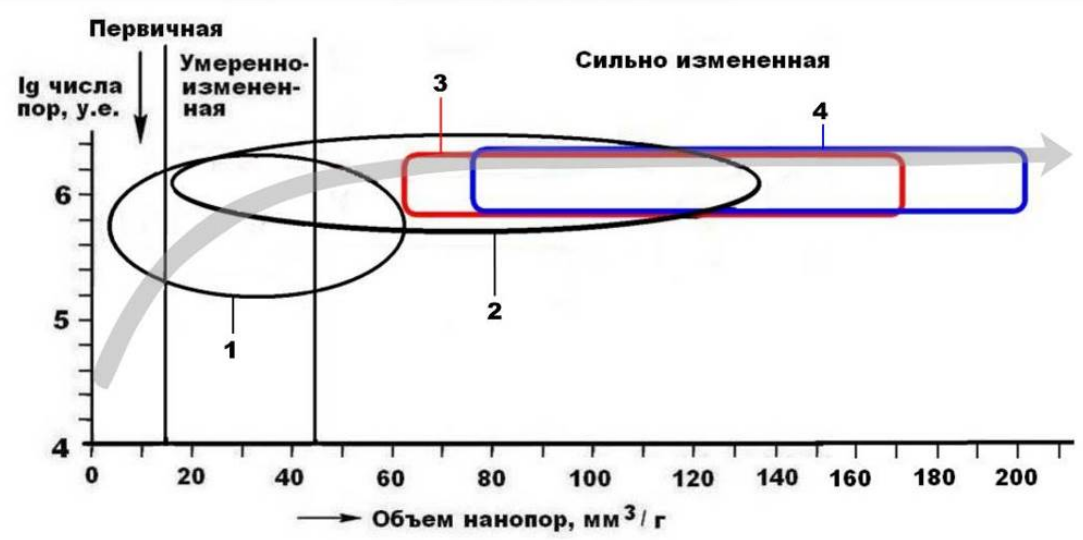

Рис. 10. Нанопористость ископаемых костей плейстоценовых мегамлекопитающих: 1, 2 - мамонтовая фауна соответственно с Печорского Приуралья (Silaev et al., 2017) и Омского Прииртышья (коллекиия А. А. Бондарева); 3, 4-иманайские соответственно пещерные львы и медведи 
Таблица 3. Характеристика нанопористости в костных остатках иманайских пещеерных львов (112) и медведей (13-26)

\begin{tabular}{|c|c|c|c|c|c|c|c|c|}
\hline № I/II & № обр. & Объект & $S_{0}, M^{2} / \Gamma$ & $\mathrm{V}_{0}, \mathrm{MM}^{3} / \boldsymbol{\Gamma}$ & $\mathrm{R}_{\mathbf{0}}, \mathrm{HM}$ & $\mathrm{V}_{0}^{\mathrm{i}}, \mathbf{H M}^{3}$ & $\mathbf{N}_{0}$ & $\lg N_{0}$ \\
\hline 1 & 492 & Позвонок & 88.97 & 168 & 2.402 & 58.07 & 2893.06 & 6.46 \\
\hline 2 & 622 & « & 75.61 & 181.7 & 4.81 & 465.41 & 390.41 & 5.59 \\
\hline 3 & 823 & « & 79.63 & 94.4 & 2.372 & 55.92 & 1688.13 & 6.23 \\
\hline 4 & 2847 & 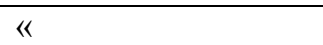 & 101.3 & 165.6 & 3.271 & 146.64 & 1129.3 & 6.05 \\
\hline 5 & 2411 & Ребро & 77.87 & 94.6 & 2.429 & 60.05 & 1575.35 & 6.23 \\
\hline 6 & 2803 & « & 62.57 & 83.2 & 2.661 & 78.95 & 1053.83 & 6.02 \\
\hline 7 & 2871 & 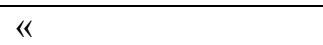 & 45.92 & 51.6 & 2.246 & 47.47 & 1087.0 & 6.04 \\
\hline 8 & 2987 & Сесамовидная кость & 75.98 & 157.5 & 4.146 & 298.61 & 527.75 & 5.72 \\
\hline 9 & 3046 & « & 55.31 & 66.1 & 2.39 & 57.2 & 1155.59 & 6.06 \\
\hline 10 & 3111 & « & 46.19 & 53.3 & 2.307 & 51.45 & 1035.96 & 6.01 \\
\hline 11 & 2974 & Фаланга & 82.18 & 102.7 & 2.499 & 65.39 & 1570.58 & 6.2 \\
\hline 12 & 2975 & Клык & 122.7 & 220.7 & 3.597 & 195 & 1131.79 & 6.05 \\
\hline \multicolumn{3}{|c|}{ Среднее } & 75.5 & 116.77 & 2.88 & 125.66 & 1285.27 & 6.06 \\
\hline \multicolumn{3}{|l|}{ СКО } & 21.45 & 55.01 & 0.82 & 126.38 & 615.17 & 0.22 \\
\hline \multicolumn{3}{|c|}{ Коэффициент вариации, \% } & 28.4 & 41.1 & 28.5 & 3.6 & 47.9 & 3.6 \\
\hline 13 & $1 / 2$ & Череп & 82.02 & 152.4 & 3.717 & 215.17 & 708.28 & 5.85 \\
\hline 14 & $(10+11) / 1$ & Челюсть & 99.35 & 120.7 & 2.43 & 60.12 & 2024.28 & 6.3 \\
\hline 15 & $3 / 1$ & Атлант & 121 & 269.2 & 4.45 & 369.23 & 729.08 & 5.86 \\
\hline 16 & $3 / 2$ & Ребро & 67.8 & 84.3 & 2.448 & 64.32 & 1310.63 & 6.12 \\
\hline 17 & 8 & Бедро & 61.34 & 63.6 & 2.074 & 37.38 & 1701.44 & 6.23 \\
\hline 18 & 2 & Кость метаподия & 89.95 & 165.9 & 3.689 & 210.35 & 788.68 & 5.9 \\
\hline 19 & $12 \mathrm{M}$ & « & 98.7 & 129.3 & 2.62 & 75.36 & 1715.76 & 6.23 \\
\hline 20 & $1 / 1$ & Фаланга & 82.02 & 152.4 & 3.717 & 215.17 & 708.28 & 5.85 \\
\hline 21 & 9 & « & 111.3 & 201.1 & 3.631 & 200.6 & 1002.49 & 6.0 \\
\hline 22 & $12 \phi$ & « & 102.3 & 115.7 & 2.262 & 48.49 & 2447.93 & 6.38 \\
\hline 23 & $4 / 16$ & Премоляр & 51.97 & 83.5 & 3.215 & 139.24 & 599.68 & 5.78 \\
\hline 24 & $4 / 2$ & Моляр & 34.39 & 39 & 2.268 & 48.88 & 797.87 & 5.9 \\
\hline 25 & 7 & Клык нижний & 111.3 & 171.2 & 3.075 & 121.83 & 1405.24 & 6.15 \\
\hline 26 & $(10+11) / 2$ & Премоляр нижний & 130.4 & 305.4 & 3.15 & 131.34 & 2325.26 & 6.19 \\
\hline \multicolumn{3}{|c|}{ Среднее } & 88.36 & 140.01 & 3.09 & 145.03 & 1304.64 & 6.04 \\
\hline \multicolumn{3}{|l|}{ СКО } & 27.61 & 62.25 & 0.76 & 103.34 & 641.94 & 0.21 \\
\hline \multicolumn{3}{|c|}{ Коэффициент вариации, \% } & 31.2 & 44.5 & 24.6 & 71.2 & 49.2 & 3.5 \\
\hline
\end{tabular}

Примечание. $\mathrm{S}_{\mathrm{o}}, \mathrm{m}^{2} / \Gamma-$ удельная поверхность нанометровых пор; $\mathrm{V}_{\mathrm{o}}, \mathrm{Mм}^{3} / \Gamma-$ совокупный объем пор; $\mathrm{R}_{\mathrm{o}}$, нм средний размер пор; $\mathrm{V}_{\mathrm{o}}^{\mathrm{i}}$, нм${ }^{3}$ - объем единичной поры; $\mathrm{N}_{\mathrm{o}}-$ условное количество пор на удельный объем.

Степень фоссилизации костей в изученной коллекции различна. Кости пещерных львов демонстрируют большую измененность, чем кости медведей, что проявляется в степени коллофанизации костного биоапатита.

Важнейшей структурной характеристикой костного композита является ультрапористость в нанометровом диапазоне, которая сильно деградирует в ходе фоссилизации, характеризуя степень вторичного изменения и относительный возраст ископаемых костей. Пещерные кости отличаются более раз- рушенной наноструктурой (табл. 3), чем того же возраста кости млекопитающих, захороненных во внепещерных обстановках (рис. 10). Костный детрит пещерных медведей статистически демонстрирует большую степень деградации наноструктуры, чем кости львов. Выявляется однотипная для львов и медведей последовательность увеличения степени изменения анатомических разностей костей в направлении от зубов к ребрам, бедренным и сесамовидным костям и далее к черепным и челюстным фрагментам, костям метаподия, атланту и фалангам. 


\section{Химический и нормативно-минеральный составы}

На валовый химический состав анализировались смывы грунтовых загрязнений с костей и сами кости пещерных животных. Полученные результаты пересчитывались на нормативно-минеральный состав.

По химическому составу смывы с костей (табл. 4,5 ) оказались довольно близкими к составу пещерных грунтов, что свидетельствует об автохтонности исследуемого костного детрита по отношению к костеносному пещерному элювию. В нормативно-минеральный состав смывов входят кварц, полевые шпаты, филлосиликаты (слюды и хлориты), а в львиных костях еще и пирит. Тем не менее в составе смывов от 50 до $65 \%$ приходится на апатит и карбонаты. Появление этих минералов в смывах отражает, очевидно, результат гидролитического разложения костного биоапатита в условиях карстовых пещер. Принципиальное уравнение соответствующей химической реакции может быть представлено в следующем виде: $\mathrm{Ca}_{10}\left[\left(\mathrm{P}_{6}\right.\right.$ $\left.{ }_{\mathrm{x}} \mathrm{C}_{\mathrm{x}} \mathrm{O}_{24}\right](\mathrm{OH})_{2-\mathrm{x}}+10 \mathrm{HCO}_{3}^{-}+\mathrm{xCa}^{2+}+(2-\mathrm{x}) \mathrm{H}^{+}=$ $(10+x) \mathrm{Ca}\left[\mathrm{CO}_{3}\right]+(6-\mathrm{x}) \mathrm{HPO}_{3}+(8-\mathrm{x}) \mathrm{OH}$.
Костные остатки пещерных львов и медведей по валовому химическому составу (табл. 6) в целом близки, за исключением некоторых компонентов. Так, в костях медведей обнаруживается в два раза больше $\mathrm{SiO}_{2}$, в три раза больше $\mathrm{Fe}_{2} \mathrm{O}_{3}$ и раз в 30 больше $\mathrm{MnO}$. Пересчет этих данных на нормативноминеральный состав показывает, что содержание иллювиированных в кость минеральных загрязнений колеблется в пределах 1-7 мол. \% у львов и 0.8-17 мол. \% у медведей (табл. 7). Этот результат разительно отличается от данных по костям, фоссилизированным во внепещерных обстановках. В последних содержание иллювиированной минеральной примеси может достигать 50 мол. $\%$ и даже более (Silaev et al., 2917; Силаев и др., 2019).

По содержанию нормативных минералов в иллювиированных загрязнениях исследованные кости несколько различаются: в медвежьих костях больше кварца и слюды, раза в 4 больше $\mathrm{Fe}-\mathrm{Mn}$ оксигидроксидов, но в 3.5-4 раза меньше хлоритов и почти нет пирита.

Таблица 4. Химический (мас. \%) и нормативно-минеральный (мол. \%) составы смыва грунтов с костей иманайских пещерных львов

\begin{tabular}{|c|c|c|c|c|c|c|c|c|}
\hline Компоненты & 492 & 622 & 823 & 2411 & 2847 & 2974 & 2975 & Статистика \\
\hline $\mathrm{SiO}_{2}$ & 35.7 & 28.78 & 31.77 & 31.19 & 33.56 & 36.07 & 28.83 & $32.27 \pm 2.98$ \\
\hline $\mathrm{TiO}_{2}$ & 0.35 & 0.56 & 0.67 & 0.41 & 0.34 & 0.35 & 0.33 & $0.43 \pm 0.13$ \\
\hline $\mathrm{Al}_{2} \mathrm{O}_{3}$ & 7.75 & 6.21 & 6.87 & 9.43 & 7.6 & 8.13 & 7.27 & $7.51 \pm 1.02$ \\
\hline $\mathrm{Fe}_{2} \mathrm{O}_{3}$ & 2.23 & 4.99 & 5.29 & 3.21 & 2.5 & 2.42 & 2.24 & $3.27 \pm 1.32$ \\
\hline $\mathrm{Cr}_{2} \mathrm{O}_{3}$ & H. o. & 0.09 & H. o. & H. o. & 0.03 & 0.03 & H. o. & $0.02 \pm 0.03$ \\
\hline $\mathrm{NiO}$ & « & 0.05 & « & 0.03 & 0.02 & 0.02 & 0.02 & $0.02 \pm 0.02$ \\
\hline $\mathrm{ZnO}$ & 0.08 & 0.25 & 0.24 & 0.12 & 0.17 & 0.09 & 0.11 & $0.15 \pm 0.07$ \\
\hline $\mathrm{MnO}$ & 0.08 & 0.16 & 0.15 & 0.14 & 0.09 & 0.09 & 0.1 & $0.12 \pm 0.03$ \\
\hline $\mathrm{MgO}$ & 1.94 & 1.29 & 1.22 & 3.1 & 1.94 & 2.09 & 1.81 & $1.91 \pm 0.62$ \\
\hline $\mathrm{CaO}$ & 36.2 & 43.83 & 39.18 & 37.27 & 34.79 & 32.68 & 41.18 & $37.88 \pm 3.82$ \\
\hline $\mathrm{SrO}$ & H. o. & 0.05 & 0.03 & H. o. & 0.02 & 0.02 & 0.01 & $0.02 \pm 0.02$ \\
\hline $\mathrm{Na}_{2} \mathrm{O}$ & 0.2 & 0.18 & H. o. & 0.16 & 0.21 & 0.25 & 0.18 & $0.17 \pm 0.08$ \\
\hline $\mathrm{K}_{2} \mathrm{O}$ & 0.98 & 1.16 & 1.2 & 1.37 & 0.99 & 1.05 & 0.95 & $1.1 \pm 0.15$ \\
\hline $\mathrm{P}_{2} \mathrm{O}_{5}$ & 14.34 & 12.21 & 13.25 & 7.77 & 14.42 & 13.59 & 12.72 & $12.61 \pm 2.28$ \\
\hline $\mathrm{SO}_{3}$ & 0.15 & 0.19 & 0.13 & 5.8 & 3.32 & 3.12 & 4.25 & $2.42 \pm 2.29$ \\
\hline $\mathrm{Ca} / \mathrm{P}_{\text {ат }}$ & 3.2 & 4.55 & 3.75 & 6.15 & 3.32 & 3.12 & 4.25 & $4.05 \pm 1.07$ \\
\hline Апатит & 35.19 & 29.91 & 35.41 & 18.13 & 36.54 & 34.56 & 26.12 & $30.84 \pm 6.72$ \\
\hline Кальцит & 14.72 & 34.53 & 19.18 & 40.44 & 30.25 & 16.8 & 39.58 & $27.93 \pm 10.92$ \\
\hline Кварц & 25.39 & 16.93 & 22.53 & 14.1 & 23.51 & 28.68 & 15.05 & $20.88 \pm 5.57$ \\
\hline Полевые шпаты & 1.71 & 1.43 & Не опр. & 1.17 & 1.78 & 2.18 & 1.37 & $1.38 \pm 0.69$ \\
\hline Слюда & 7.64 & 8.54 & 11.0 & 9.38 & 7.73 & 8.78 & 6.67 & $8.53 \pm 1.4$ \\
\hline Хлориты & 15.2 & 8.42 & 11.73 & 16.69 & 0.08 & 8.83 & 11.1 & $10.29 \pm 5.44$ \\
\hline Пирит & 0.15 & 0.24 & 0.15 & 0.09 & 0.11 & 0.17 & 0.11 & $0.15 \pm 0.05$ \\
\hline
\end{tabular}


Таблица 5. Химический (мас. \%) и нормативно-минеральный (мол. \%) состав смывва грунтов с костей иманайских пещерных медведей

\begin{tabular}{|c|c|c|c|c|c|c|c|c|c|c|}
\hline Компоненты & $1 / 1$ & 2 & $3 / 1$ & $4 / 1$ & 7 & 8 & 9 & $(10+11) / 1$ & 12 & Статистика \\
\hline $\mathrm{SiO}_{2}$ & 37.08 & 32.0 & 33.9 & 34.52 & 35.37 & 37.83 & 39.83 & 42.03 & 50.97 & $38.17 \pm 7.7$ \\
\hline $\mathrm{TiO}_{2}$ & 0.38 & 0.32 & 0.37 & 0.38 & 0.43 & 0.46 & 0.47 & 0.59 & 0.77 & $0.46 \pm 0.14$ \\
\hline $\mathrm{ZrO}^{2}$ & H. o. & H. o. & 0.02 & H. o. & H. o. & 0.02 & 0.02 & 0.02 & H. o. & $0.01 \pm 0.01$ \\
\hline $\mathrm{Al}_{2} \mathrm{O}_{3}$ & 8.9 & 7.17 & 8.24 & 8.1 & 8.18 & 8.83 & 9.43 & 10.43 & 13.9 & $9.24 \pm 1.97$ \\
\hline $\mathrm{Fe}_{2} \mathrm{O}_{3}$ & 2.66 & 1.92 & 2.49 & 2.54 & 2.51 & 2.74 & 2.85 & 3.34 & 4.13 & $2.8 \pm 0.62$ \\
\hline $\mathrm{Cr}_{2} \mathrm{O}_{3}$ & 0.04 & H. o. & 0.03 & 0.03 & 0.03 & 0.03 & 0.03 & 0.03 & & $0.03 \pm 0.01$ \\
\hline $\mathrm{NiO}$ & 0.02 & $\ll$ & 0.01 & 0.02 & 0.02 & 0.02 & 0.02 & 0.02 & 0.03 & $0.02 \pm 0.01$ \\
\hline $\mathrm{CuO}$ & 0.01 & « & 0.01 & H. o. & H. o. & H. o. & H. o. & H. o. & H. o. & $0.002 \pm 0.004$ \\
\hline $\mathrm{ZnO}$ & 0.08 & 0.09 & 0.08 & 0.06 & 0.07 & $0 / 05$ & 0.09 & 0.05 & 0.05 & $0.07 \pm 0.02$ \\
\hline $\mathrm{MnO}$ & 0.08 & 0.06 & 0.09 & 0.06 & 0.09 & 0.18 & 0.13 & 0.12 & 0.15 & $0.11 \pm 0.04$ \\
\hline $\mathrm{MgO}$ & 2.48 & 2.12 & 1.51 & 2.29 & 1.97 & 1.59 & 2.11 & 2.0 & 2.24 & $2.03 \pm 0.32$ \\
\hline $\mathrm{CaO}$ & 32.73 & 39.66 & 36.57 & 38.72 & 38.51 & 32.63 & 30.08 & 31.4 & 20.62 & $33.44 \pm 5.95$ \\
\hline $\mathrm{SrO}$ & 0.02 & H. o.. & 0.02 & 0.02 & 0.01 & 0.02 & 0.02 & 0.02 & H. o. & $0.01 \pm 0.01$ \\
\hline $\mathrm{Na}_{2} \mathrm{O}$ & 0.21 & 0.29 & 0.2 & 0.17 & 0.16 & 0.2 & 0.19 & 0.14 & 0.1 & $0.18 \pm 0.05$ \\
\hline $\mathrm{K}_{2} \mathrm{O}$ & 1.15 & 0.99 & 0.95 & 0.99 & 0.97 & 1.0 & 1.14 & 1.17 & 1.53 & $1.1 \pm 0.18$ \\
\hline $\mathrm{P}_{2} \mathrm{O}_{5}$ & 13.99 & 15.24 & 15.4 & 12.01 & 11.6 & 14.27 & 13.49 & 8.58 & 5.44 & $12.22 \pm 3.31$ \\
\hline $\mathrm{SO}_{3}$ & 0.17 & 0.14 & 0.11 & 0.09 & 0.08 & 0.13 & 0.1 & 0.06 & 0.07 & $0.11 \pm 0.04$ \\
\hline $\mathrm{Ca} / \mathrm{P}_{\text {ат }}$ & 2.97 & 3.3 & 3.01 & 4.09 & 4.21 & 2.9 & 2.83 & 4.64 & 4.81 & $3.64 \pm 0.79$ \\
\hline Апатит & 34.72 & 37.76 & 38.42 & 29.67 & 28.68 & 35.72 & 33.60 & 21.2 & 13.49 & $30.36 \pm 8.29$ \\
\hline Кальцит & 11.21 & 16.37 & 12.95 & 20.63 & 21.12 & 10.72 & 9.25 & 18.67 & 12.64 & $14.84 \pm 4.47$ \\
\hline Кварц & 22.5 & 19.93 & 20.26 & 21.06 & 21.78 & 23.31 & 24.39 & 24.81 & 29.33 & $23.04 \pm 2.91$ \\
\hline Полевые шпаты & 2.0 & 2.76 & 1.92 & 1.61 & 1.52 & 1.89 & 1.8 & 1.32 & 0.94 & $1.75 \pm 0.51$ \\
\hline Слюда & 10.07 & 8.66 & 8.35 & 8.63 & 8.44 & 8.83 & 10.03 & 10.2 & 13.32 & $9.61 \pm 1.58$ \\
\hline Хлориты & 19.5 & 14.52 & 18.1 & 18.4 & 18.46 & 19.53 & 20.93 & 23.8 & 30.28 & $20.39 \pm 4.45$ \\
\hline
\end{tabular}

Примечание. Н.о. - не обнаружен.

Следовательно, получается, что кости пещерных львов и медведей фоссилизировались в нетождественных Еh-условиях - кости львов в какой-то период пребывали в более восстановительных условиях (образование пирита), а кости медведей, напротив, в более окислительных (оксигидроксидное омарганцевание).

Важнейшей особенностью фоссилизации исследуемых костей является их кальцитизация, т. е. замещение исходного биоапатита карбонатами. Это коррелируется с отмеченной выше фосфатизацией пещерноэлювиальных грунтов, обусловленной привносом в них замещенной в костях части фосфатного вещества. Такая картина вполне закономерна, поскольку костный детрит иманайских плейстоценовых млекопитающих был захоронен в карстогенной пещере. Прямое определение карбонатности костей осуществлялось химико-аналитическим методом. Анализ показал, что в костном детрите пещерных львов содержание $\mathrm{CO}_{2}$ варьируется в пределах 6.5-17.5 мас. \%, возрастая в последовательности: (зубы, клыки) < сеса- мовидные кости $<$ позвонки $<$ (рёбра, фаланги). В среднем это составляет $12.29 \pm 3.41$ мас. \%. В костном детрите пещерных медведей содержание $\mathrm{CO}_{2}$ колеблется в пределах 6-17.5 мас. \%, увеличиваясь в направлении от зубов и клыков к фрагментам черепа, челюсти, атланта, далее к бедренной кости, фалангам и костям метаподия. Средние данные составляют $(10.66 \pm 4.24)$ мас. \%. Согласно расчетам, содержания $\mathrm{CO}_{2}$ в пещерных костях прямо и очень сильно ( $\mathrm{r}=0.82-0.88)$ коррелируются с атомным отношением $\mathrm{Ca} / \mathrm{P}$, из чего следует, что кальцитизация пещерных костей имеет наложенный, эпигенетический характер.

Из результатов сравнительного анализа видно, что иманайские пещерные кости по содержанию $\mathrm{CO}_{2}$ значительно преобладают над примерно одновозрастными костями плейстоценовых млекопитающих, фоссилизированными во внепещерных обстановках (рис. 11), что, очевидно, обусловлено нетронутостью последних эпигенетической кальцитизацией. 
Таблица 6. Химический состав костей пещерных львов (1-14) и медведей (15-29), мас. \%

\begin{tabular}{|c|c|c|c|c|c|c|c|c|c|c|c|c|c|c|c|c|}
\hline Q n/I/n & № обр & $\mathrm{SiO}_{2}$ & $\mathrm{TiO}_{2}$ & $\left|\mathbf{A l}_{2} \mathbf{O}_{3}\right|$ & $\mathrm{Fe}_{2} \mathrm{O}_{3}$ & $\mathrm{MnO}$ & MgO & $\mathrm{CaO}$ & SrO & $\mathrm{ZnO}$ & $\mathbf{N i O}$ & $\mathrm{Na}_{2} \mathrm{O}$ & $\mathrm{K}_{2} \mathrm{O}$ & $\mathbf{P}_{2} \mathbf{O}_{5}$ & $\mathrm{SO}_{3}$ & $\mathbf{C a} / \mathbf{P}_{\mathrm{aT}}$ \\
\hline 1 & 622 & 1.42 & o. & 0.44 & 0.22 & H. 0. & 0.79 & 64.12 & 0.04 & 0.07 & H. 0 . & 0.49 & 0.07 & 32.26 & 0.08 & 2.52 \\
\hline 2 & 823 & 90 & $\ll$ & 0.44 & .13 & $\ll$ & 0.76 & 60.20 & 0.04 & \begin{tabular}{|l|}
0.07 \\
\end{tabular} & « & 0.58 & 0.05 & 36.70 & 0.13 & 2.08 \\
\hline 3 & 2847 & \begin{tabular}{|l|}
0.56 \\
\end{tabular} & « & \begin{tabular}{|l|}
0.17 \\
\end{tabular} & 0.11 & « & \begin{tabular}{|l|}
0.75 \\
\end{tabular} & 63.10 & 0.04 & \begin{tabular}{|l|}
0.08 \\
\end{tabular} & « & 0.55 & H. 0. & 34.52 & \begin{tabular}{|l|}
0.12 \\
\end{tabular} & 2.32 \\
\hline 4 & 492 & \begin{tabular}{|l|}
1.01 \\
\end{tabular} & « & \begin{tabular}{|l|}
0.28 \\
\end{tabular} & 0.13 & 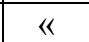 & 0.72 & 62.27 & \begin{tabular}{|l|}
0.03 \\
\end{tabular} & \begin{tabular}{|l|}
0.04 \\
\end{tabular} & & 0.59 & 0.03 & 34.78 & \begin{tabular}{|l|}
0.12 \\
\end{tabular} & 2.27 \\
\hline 5 & 369 & 1.73 & « & \begin{tabular}{|l|}
0.59 \\
\end{tabular} & 0.20 & « & 0.80 & 62.25 & 0.05 & 0.10 & « & .35 & 0.06 & 33.75 & .12 & 2.33 \\
\hline 6 & & 87 & « & .57 & .19 & 《 & & 60.69 & & \begin{tabular}{|l|}
0.06 \\
\end{tabular} & & .30 & 0.06 & 5.28 & \begin{tabular}{|l|}
0.12 \\
\end{tabular} & 2.18 \\
\hline 7 & 11 & 60 & « & 28 & 14 & « & 83 & 63.57 & 0.03 & 0.06 & & .53 & 0.04 & 33.82 & 0.10 & 2.38 \\
\hline 8 & 71 & 43 & « & 68 & 0.36 & \begin{tabular}{|l|}
0.04 \\
\end{tabular} & 0.80 & 62.97 & 0.04 & \begin{tabular}{|l|}
0.10 \\
\end{tabular} & « & .49 & 0.08 & 31.93 & \begin{tabular}{|l|}
0.08 \\
\end{tabular} & 2.50 \\
\hline 9 & 11 & \begin{tabular}{|l|}
1.16 \\
\end{tabular} & « & \begin{tabular}{|l|}
0.47 \\
\end{tabular} & 0.17 & \begin{tabular}{|l|} 
H. $о$. \\
\end{tabular} & \begin{tabular}{|l|}
0.93 \\
\end{tabular} & 63.55 & 0.05 & 0.09 & « & 0.57 & 0.05 & 32.78 & \begin{tabular}{|l|l|}
0.18 \\
\end{tabular} & 2.45 \\
\hline 10 & 2987 & \begin{tabular}{|l|}
1.33 \\
\end{tabular} & « & \begin{tabular}{|l|}
0.49 \\
\end{tabular} & 0.18 & « & \begin{tabular}{|l|l|}
0.69 \\
\end{tabular} & 58.93 & 0.04 & 0.05 & & 0.45 & 0.07 & 37.57 & 0.20 & 1.99 \\
\hline 11 & 46 & 0.45 & $n$ & \begin{tabular}{|l|}
0.18 \\
\end{tabular} & 0.11 & H. $о$. & \begin{tabular}{|l|}
0.78 \\
\end{tabular} & 61.82 & 0.03 & \begin{tabular}{|l|}
0.09 \\
\end{tabular} & & 0.51 & H. o. & 35.87 & \begin{tabular}{|l|}
0.16 \\
\end{tabular} & 2.18 \\
\hline 12 & 29 & 3.50 & 0.07 & 1.05 & 0.42 & 0.02 & 0.94 & 48 & 0.05 & 0.10 & & 54 & 0.13 & .57 & 0.13 & 2.47 \\
\hline 13 & 2975 & 0.33 & H. o. & 0.12 & .06 & H. 0. & 0.8 & 59.94 & 0.05 & 0.08 & & 34 & 0.02 & 3.13 & 0.12 & 1.99 \\
\hline 14 & 3038 & 0.54 & & 20 & 0.08 & & \begin{tabular}{|l|}
0.75 \\
\end{tabular} & 61.13 & 0.05 & \begin{tabular}{|l|}
0.13 \\
\end{tabular} & & 55 & .02 & 6.41 & .13 & 2.13 \\
\hline \multicolumn{2}{|c|}{ Среднее } & \begin{tabular}{|l|}
1.27 \\
\end{tabular} & 0.01 & 0.43 & 0.18 & 0.004 & 0.8 & 61.86 & 0.04 & 0.08 & T & .49 & 0.05 & 34.67 & 0.13 & 2.27 \\
\hline & \begin{tabular}{|l|}
0.88 \\
\end{tabular} & 0.02 & 0.25 & 0.1 & \begin{tabular}{|l|}
0.01 \\
\end{tabular} & \begin{tabular}{|l|}
0.07 \\
\end{tabular} & 1.55 & 0.01 & 0.02 & 0 & 0.09 & 0.03 & 2.10 & \begin{tabular}{|l|}
0.03 \\
\end{tabular} & 0.18 \\
\hline \multicolumn{2}{|c|}{ оэф.вариации, \% } & 69 & 200 & 58 & 56 & 250 & 9 & .5 & 25 & 25 & 0 & 18 & 60 & 6 & 23 & 8 \\
\hline 15 & ИМ-1/1 & \begin{tabular}{|l|}
1.76 \\
\end{tabular} & H. 0. & $\begin{array}{l}0.53 \\
\end{array}$ & 1.95 & 0.77 & 1.06 & 57.03 & 0. & H. $о$. & H. 0 . & 0.12 & 0.08 & 36.32 & \begin{tabular}{|l|l|}
0.38 \\
\end{tabular} & 1.99 \\
\hline 16 & И & 4.2 & 0.06 & 20 & 0.45 & 0. & 0.98 & & 0.05 & 0.08 & $\ll$ & .39 & .15 & 35.03 & .11 & 2.33 \\
\hline 17 & {$[-2$} & 1.26 & H.o. & 0.38 & 16 & 0.01 & \begin{tabular}{|l|}
0.92 \\
\end{tabular} & 63.33 & 0.03 & 0.09 & & 0.56 & 0.05 & 33.07 & 0.14 & 2.43 \\
\hline 18 & {$[-3 / 1$} & \begin{tabular}{|l|}
1.89 \\
\end{tabular} & & \begin{tabular}{|l|}
0.50 \\
\end{tabular} & 0.22 & \begin{tabular}{|l|}
0.02 \\
\end{tabular} & \begin{tabular}{|l|}
0.79 \\
\end{tabular} & 57.98 & 0.02 & 0.08 & & .66 & 0.07 & 37.70 & \begin{tabular}{|l|l|}
0.07 \\
\end{tabular} & 1.95 \\
\hline 19 & ИМ-3/2 & \begin{tabular}{|l|}
11.21 \\
\end{tabular} & \begin{tabular}{|l|}
0.15 \\
\end{tabular} & 2.99 & 0.96 & \begin{tabular}{|l|}
0.05 \\
\end{tabular} & 1.14 & 55.25 & 0.03 & 0.10 & & 0.41 & 0.34 & 27.25 & \begin{tabular}{|l|}
0.12 \\
\end{tabular} & 2.57 \\
\hline 20 & ИМ-4/1a & 1.56 & H. 0. & 0.44 & 0.26 & 0.01 & 0.65 & 58.58 & 0.03 & 0.08 & $\pi$ & 0.64 & 0.07 & 37.57 & 0.11 & 2.02 \\
\hline 21 & ИМ-4/1б & 1.53 & 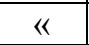 & 0.48 & 0.14 & 0.01 & 0.76 & 56.69 & 0.04 & 0.03 & « & 0.65 & 0.06 & 39.46 & 0.15 & 1.82 \\
\hline 22 & & 1.1 & « & H. 0 . & 0.24 & 10 & 0. & 59 & 0.06 & 0.09 & & 8 & 05 & 37.19 & 11 & 2.07 \\
\hline 23 & & 6.42 & 4 & 0.08 & 0.53 & & 0. & 66 & 0.05 & 0.05 & & 16 & 18 & 57 & 11 & 2.28 \\
\hline 24 & M-9 & 0.57 & 4 & H. 0. & 0.46 & 0.0 & \begin{tabular}{|l|}
0.77 \\
\end{tabular} & 58.44 & 0.04 & 0.11 & & .44 & 0.02 & 39.02 & 0.08 & 1.90 \\
\hline 25 & ИМ-10 & 8.58 & « & 0.17 & 1.02 & 0.01 & 1.35 & 58.69 & 0.05 & 0.08 & « & 0.42 & 0.23 & 29.30 & \begin{tabular}{|l|}
0.10 \\
\end{tabular} & 2.52 \\
\hline 26 & $\mathrm{M}-(10+11) / 1$ & 0.44 & « & H. 0. & 0.09 & 0.03 & 0.75 & 60.84 & 0.05 & 0.11 & « & 0.47 & 0.01 & 37.14 & 0.07 & 2.08 \\
\hline 27 & ИМ-(10+11)/2 & 1.04 & « & « & 0.13 & 0.01 & \begin{tabular}{|l|}
0.80 \\
\end{tabular} & 58.98 & 0.05 & 0.07 & $\ll$ & 0.43 & 0.03 & 38.37 & 0.09 & 1.95 \\
\hline 28 & ИМ-12M & 1.65 & « & 0.50 & 0.17 & 0.20 & 0.81 & 60.39 & 0.05 & 0.09 & 0.02 & 0.41 & 0.05 & 35.58 & 0.10 & 2.15 \\
\hline 29 & ИМ-12ф & 0.79 & 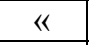 & 0.32 & 0.12 & 0.40 & 0.77 & 60.69 & 0.05 & 0.05 & H. 0 & 0.43 & 0.04 & 36.23 & 0.11 & 2.12 \\
\hline \multicolumn{2}{|c|}{ Среднее } & 2.94 & 0.01 & 0.51 & 0.46 & 0.12 & 0.88 & $58 . .84$ & 0.04 & 0.07 & 0.005 & 0.46 & 0.1 & 35.45 & 0.12 & 2.14 \\
\hline \multicolumn{2}{|r|}{ СКО } & 3.25 & 0.04 & 0.76 & 0.51 & 0.2 & 0.18 & 1.99 & 0.02 & 0.03 & 0.02 & 0.13 & 0.09 & 3.52 & 0.07 & 0.23 \\
\hline \multicolumn{2}{|c|}{ Коэф.вариации, \% } & 110 & 400 & 149 & 111 & 175 & 20 & 2 & 50 & 43 & 400 & 28 & 90 & 10 & 58 & 11 \\
\hline
\end{tabular}

Таблица 7. Нормативно-минеральный состав костей пещеерных львов (1-14) и медведей (15-29), мол. \%

\begin{tabular}{|l|l|l|l|l|l|l|l|l|}
\hline $\begin{array}{l}\text { № } \\
\text { п/п }\end{array}$ & № обр. & $\begin{array}{l}\text { Апатит + } \\
\text { кальцит }\end{array}$ & Кварц & $\begin{array}{l}\text { Полевые } \\
\text { шпаты }\end{array}$ & Слюда & Хлориты & Пирит & $\begin{array}{l}\text { Fе-Мп окси- } \\
\text { гидроксиды }\end{array}$ \\
\hline 1 & 622 & 96.58 & 0.95 & Не опр. & 0.54 & 1.51 & 0.13 & 0.29 \\
\hline 2 & 823 & 97.62 & 0.35 & « & 0.35 & 1.42 & 0.2 & 0.06 \\
\hline 3 & 2847 & 98.28 & 0.31 & « & Не опр. & 1.18 & 0.18 & 0.05 \\
\hline 4 & 492 & 97.7 & 0.64 & « & 0.21 & 1.2 & 0.18 & 0.07 \\
\hline 5 & 2869 & 96.49 & 0.94 & « & 0.42 & 1.83 & 0.18 & 0.14 \\
\hline 6 & 2803 & 96.37 & 1.11 & « & 0.42 & 1.79 & 0.18 & 0.13 \\
\hline 7 & 2411 & 98.0 & 0.24 & « & 0.28 & 1.24 & 0.15 & 0.09 \\
\hline 8 & 2871 & 95.78 & 1.82 & « & 0.35 & 1.61 & 0.12 & 0.32 \\
\hline 9 & 3111 & 97.03 & 0.53 & « & 0.35 & 1.74 & 0.27 & 0.08 \\
\hline 10 & 2987 & 97.08 & 0.7 & « & 0.49 & 1.4 & 0.30 & 0.08 \\
\hline 11 & 3046 & 98.31 & 0.18 & « & Не опр. & 1.24 & 0.24 & 0.03 \\
\hline 12 & 2974 & 93.27 & 1.31 & 2.71 & 0.91 & 1.24 & 0.2 & 0.36 \\
\hline 13 & 2975 & 99.05 & 0.18 & Не опр. & 0.14 & 0.45 & 0.18 & Не опр. \\
\hline 14 & 3038 & 98.31 & 0.27 & « & 0.1 & 1.11 & 0.19 & 0.02 \\
\hline Среднее & 97.13 & 0.68 & 0.19 & 0.35 & 1.35 & 0.19 & 0.12 \\
\hline
\end{tabular}


Окончание табл. 7

\begin{tabular}{|c|c|c|c|c|c|c|c|c|}
\hline $\begin{array}{l}\text { № } \\
\text { II/II }\end{array}$ & \begin{tabular}{|l|} 
№ oбp. \\
\end{tabular} & $\begin{array}{l}\text { Апатит + } \\
\text { кальцит }\end{array}$ & Кварц & $\begin{array}{l}\text { Полевые } \\
\text { шпаты }\end{array}$ & Слюда & Хлориты & Пирит & $\begin{array}{l}\text { Fe-Mn окси- } \\
\text { гидроксиды }\end{array}$ \\
\hline \multicolumn{2}{|c|}{$\mathrm{CKO}$} & 1.45 & 0.49 & 0.72 & 0.23 & 0.35 & 0.12 & 0.12 \\
\hline \multicolumn{2}{|c|}{ Коэф. вариации, \% } & 1.5 & 72 & 379 & 66 & 26 & 63 & 100 \\
\hline 15 & $1 / 1$ & 94.59 & 0.64 & 1.21 & 0.65 & 0.65 & Не опр. & 2.26 \\
\hline 16 & $1 / 2$ & 92.75 & 1.26 & 3.85 & 1.37 & 0.4 & « & 0.37 \\
\hline 17 & 2 & 97.38 & Не опр. & 2.15 & 0.34 & Не опр. & « & 0.13 \\
\hline 18 & $3 / 1$ & 96.66 & 0.13 & 2.56 & 0.46 & $\ll$ & « & 0.19 \\
\hline 19 & $3 / 2$ & 83.12 & 5.45 & 4.0 & 3.06 & 3.61 & « & 0.77 \\
\hline 20 & $4 / 1 \mathrm{a}$ & 97.31 & 0.57 & 1.26 & 0.65 & Не опр. & 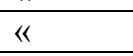 & 0.21 \\
\hline 21 & $4 / 6$ & 96.98 & Не опр. & 2.5 & 0.4 & « & « & 0.12 \\
\hline 22 & $4 / 2$ & 99.7 & « & Не опр. & Не опр. & « & 0.13 & 0.17 \\
\hline 23 & 8 & 93.13 & 5.95 & $\ll$ & 0.46 & « & Не опр. & 0.47 \\
\hline 24 & 9 & 99.01 & 0.59 & « & Не опр. & « & « & 0.4 \\
\hline 25 & 10 & 89.91 & 8.19 & 1.11 & $\ll$ & $\ll$ & $\ll$ & 0.79 \\
\hline 26 & $(10+11) / 1$ & 99.46 & 0.45 & Не опр. & $\ll$ & 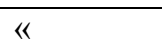 & 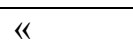 & 0.09 \\
\hline 27 & $(10+11) / 2$ & 98.82 & 1.07 & " & « & « & « & 0.11 \\
\hline 28 & $12 \mathrm{M}$ & 96.94 & 0.29 & 1.99 & 0.47 & « & « & 0.31 \\
\hline 29 & $12 \phi$ & 99.19 & Не опр. & 0.34 & 0.28 & 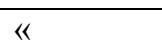 & 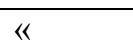 & 0.19 \\
\hline \multicolumn{2}{|c|}{ Среднее } & 95.66 & 1.64 & 1.4 & 0.54 & 0.31 & 0.01 & 0.44 \\
\hline \multirow{2}{*}{\multicolumn{2}{|c|}{ СКO }} & 4.48 & 2.62 & \begin{tabular}{|l|}
1.4 \\
\end{tabular} & \begin{tabular}{|l}
0.79 \\
\end{tabular} & 0.93 & 0.03 & 0.55 \\
\hline & & 5 & 160 & 100 & 146 & 300 & 300 & 125 \\
\hline
\end{tabular}

Непосредственное фазовое присутствие в исследуемых костях новообразованного карбоната доказывается методом рентгенолюминесцентной спектроскопии. Проведенные предварительные исследования показали, что для ископаемых костей, захороненных во внепещерных обстановках, рентгенолюминесценция не характерна. В пещерном же костном детрите она, напротив, всегда возбуждается, достигая значительной интенсивности в полосе с максимумом $630 \mathrm{Hм}$.

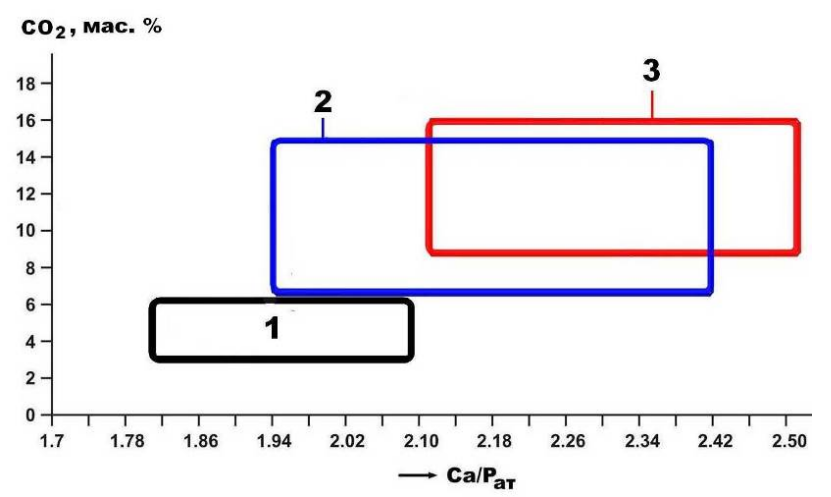

Рис. 11. Содержание $\mathrm{CO}_{2}$ в ископаемых костях как критерий степени их кальщитизации в процессе фоссилизации: 1 - мамонтовая фауна, фоссилизированная во внепещерных обстановках (Печорское Приуралье, Омское Прииртылиье); 2, 3 - кости из пещеры Иманай, соответственно медвежьи и львиные
Последнее соответствует излучению на ионах-люминофорах $\mathrm{Mn}^{2+}$ в структуре кальцита.

Среднестатистическая нормализованная интенсивность марганцевой рентгенолюминесценции костей иманайских пещерных львов и медведей составляет соответственно $(7.88 \pm 5.15)$ и $(10.12 \pm 5.44)$ отн. ед. Обобщенный анализ особенностей нормативноминерального состава костеносных грунтов, смывов с костей и иллювиированных в кости минеральных загрязнений приводит к следующим выводам (рис. 12).

Собственно пещерные грунты характеризуются промежуточным кварц-полевошпатслюдисто-Хлоритовым составом. Смыв с костей львов практически совпадает по нормативно-минеральному составу с грунтами, а смыв с костей медведей заметно обогащен относительно грунтов кварцем и полевыми шпатами. Иллювиированная в кости минеральная примесь заметно отклоняется от состава грунтов, причем для львиных и медвежьих костей разнонаправленно. В львиных костях она сильно обогащена хлоритами за счет кварца и полевых шпатов, а в медвежьих, напротив, - кварцем и полевыми шпатами за счет хлоритов. Примечательно выглядит существенное и разнонаправленное расхождение по нормативно-минеральному со- 
ставу собственно костей и смывов с них. Так, смыв с костей львов демонстрирует обогащение кварцем и полевыми шпатами, а кости содержат филлосиликаты. Анализ медвежьих костей, наоборот, показывает, что смывы имеют существенно слюдистохлоритовый состав, а кости - преимущественно кварц-полевошпатовый.

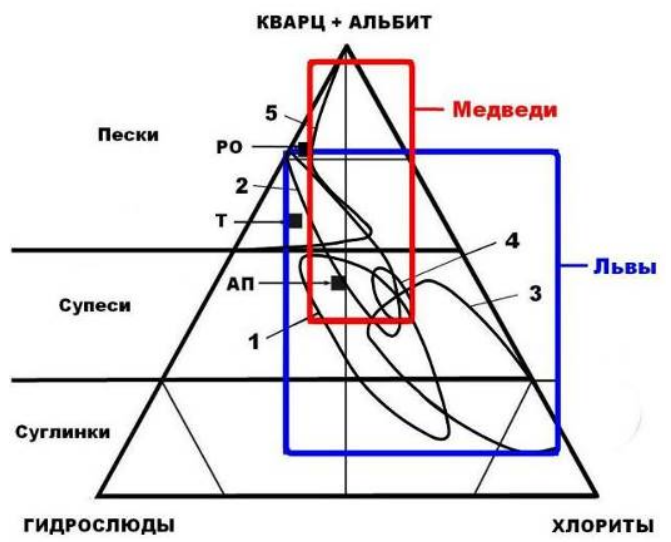

Рис. 12. Нормативно-минеральный состав костеносных грунтов, смывов с пещерных костей и иллювиированных в кости минеральных загрязнений: 1 - грунтыз; 2, 3-соответственно смывы и кости львов; 4, 5 -соответственно смывы и кости медведей. Черные квадраты - средние составы речных отложений (РО), тиллов (Т) и псаммоалевропелитовых осадков (АП)

Получается, что минеральный состав иллювиированных загрязнений выявляет различие костей львов и медведей по характеру их проницаемости для микроминеральных примесей. В целом результаты проведенных исследований указывают на автохтонность пещерных костей по отношению к костеносным грунтам и выявляют при этом нетождественность костей пещерных львов и медведей по этим свойствам и, следовательно, разную степень фоссилизации.

\section{Микроэлементы}

В составе исследуемых пещерных костей обнаружены 50 микроэлементов (табл. 8, 9), в том числе (в скобках доля в \%, первые цифры - львы, вторые - медведи) 10 элементов-эссенциалов - Э $(36.9 \pm 3.9$ и $34.6 \pm 9.1)$, 19 физиологически-активных элементов ФА $(60.9 \pm 5.6$ и $63.6 \pm 9.4)$ и 21 элементовантибионтов - АБ $(2.2 \pm 4.6$ и $1.8 \pm 3.0)$. Элементы первой группы в костях наследу- ются от живого организма, в котором они, как известно, отвечают за перенос кислорода, фиксацию азота, стимулируют метаболизм железа, углеводородный обмен, способствуют образованию ферментов, формированию структуры клеток, дифференциации и стабилизации клеточных мембран (Войнар, 1960). Вторая группа объединяет элементы, которые могут быть по происхождению как унаследованными от организма, так и ксеногенными. Третья группа включает элементы, которые по происхождению являются практически нацело ксеногенно-абиотическими, будучи заимствованными из среды захоронения. Обогащение такими элементами костей происходит не только вследствие иллювиирования в кости вещества грунтов, но и по ионообменному механизму, когда кристаллохимически активные элементы из окружающей среды замещают в костном биоапатите кальций и фосфор.

Отношение групповых содержаний элементов Э/АБ можно рассматривать как критерий оценки степени фоссилизации ископаемых костей. Так, в живом, например, бактериальном веществе вследствие громадного превосходства элементов-эссенциалов над антибионтами величина упомянутого отношения лежит в пределах 110-300 (Кокин и др., 2020).

В костном детрите плейстоценовых животных, захороненных во внепещерных обстановках, значение такого отношения колеблется в интервале 0.5-2. В иманайских же костях рассматриваемая Э/АБ-пропорция имеет промежуточные, но сильно сдвинутые в сторону живого вещества значения, варьируясь у костей львов и медведей в интервалах соответственно 20-158 $(61.39 \pm 40.15)$ и $17-79(40.83 \pm 19.51)$.

Очевидно, что полученные по иманайским костям результаты обусловлены, прежде всего, очень низким содержанием в них АБ-элементов. Следовательно, фоссилизация костей в пещерных условиях принципиально отличается от таковой во внепещерных обстановках крайне низкой степенью эпигенетического обогащения микроэлементами вмещающей геологической среды. На это указывают и значения индикаторных геохимических модулей, которые для внепещерных костей и костей иманайских львов и ме- 
Таблица 8. Микроэлементы в костном детрите иманайских пещерных львов, г/m

\begin{tabular}{|c|c|c|c|c|c|c|c|c|c|c|c|c|}
\hline Элементы & 2803 & 3046 & 3111 & 2987 & 2975 & 491 & 622 & 823 & 2847 & 2869 & 2871 & 411 \\
\hline \multicolumn{13}{|c|}{ Элементы-эссенциалы (Э) } \\
\hline $\mathrm{Ag}$ & 0.04 & 047 & 0.109 & 0.075 & 0.02 & 0.029 & 0.025 & 0.034 & 0.031 & 0.021 & 32 & .053 \\
\hline As & 1.242 & 1.308 & & 1.015 & 1.539 & 1.522 & 1.289 & 1.366 & 1.265 & & 1.381 & 1.198 \\
\hline $\mathrm{Bi}$ & Не обн. & Не обн. & 0.011 & Не обн. & Не обн. & Не обн. & Не обн. & Іе обн. & Не обн. & Не обн. & Не обн. & Не обн. \\
\hline $\mathrm{Cd}$ & 1.013 & 1.142 & 2.254 & 1.662 & 1.293 & 0.815 & 1.379 & 2.448 & 1.516 & 1.694 & 2.439 & 2.152 \\
\hline Mo & 314 & 125 & 0.185 & 431 & 309 & & 0.159 & 425 & & 147 & 0.17 & 0.402 \\
\hline $\mathrm{Se}$ & 446 & 37 & 1.968 & .88 & 963 & 164 & 327 & 183 & 2.053 & 827 & .454 & 89.501 \\
\hline $\mathrm{Rb}$ & 138 & 176 & 0.511 & 0.988 & 212 & & 1.374 & & & .069 & 2.011 & 0.948 \\
\hline $\mathrm{Pb}$ & 761 & 0.449 & & 1.016 & & 0.417 & & 575 & 0.35 & .606 & & \\
\hline Th & 158 & 0.038 & 0.053 & 0.055 & 0.019 & 0.082 & 0.153 & .087 & & 0.068 & 0.268 & 0.106 \\
\hline $\mathrm{Zn}$ & 237.794 & 306.255 & 308.027 & 306.932 & 307.708 & 267.367 & $\begin{array}{ll}7 & 271.816 \\
\end{array}$ & 359.712 & 306.29 & 381.38 & 324.385 & 287.60 \\
\hline Сумма & \begin{tabular}{|l|}
246.906 \\
\end{tabular} & 311.277 & 314742 & 314.054 & 313.275 & 273.281 & 278.042 & & 312.361 & & & \\
\hline \multicolumn{13}{|c|}{ Элементы физиологически-активные (ФА) } \\
\hline $\mathrm{Ba}$ & 1 & 1 & 83 & 150.31 & 132.745 & $\begin{array}{ll}559.802 \\
\end{array}$ & \begin{tabular}{|l|l|}
246.98 \\
\end{tabular} & 180.742 & 31 & T. & 50.500 & 47. \\
\hline $\mathrm{V}$ & 12.077 & 9.356 & 6.228 & 8.562 & 10.786 & & 8.44 & & & 8.331 & 761 & \\
\hline $\mathrm{Ga}$ & 706 & & & 0.836 & 0.762 & & .705 & & & 695 & 0.775 & 0.687 \\
\hline $\mathrm{Hf}$ & & & & 044 & & & 0047 & & & 061 & & 0.07 \\
\hline $\mathrm{Y}$ & 596 & 0.451 & & 1.238 & & & 10 & & & 27 & & 66 \\
\hline Co & 082 & & & 1.02 & 1.013 & 0.962 & 1.26 & & & 1.476 & 2.98 & 0.852 \\
\hline $\mathrm{Cu}$ & 33.124 & 37.699 & 28.029 & 21.302 & 34.241 & 15.723 & 30.97 & & & 29.338 & 31.529 & 34.522 \\
\hline $\mathrm{I}_{\mathrm{i}}$ & & & & & & & & & & & & \\
\hline $\mathrm{Mn}$ & & & 27.7 & 87.631 & 14 & 72 & 59.926 & & & 687 & & \\
\hline $\mathrm{Ni}$ & 85 & 25 & 23.283 & 25.62 & 20.752 & 19. & 26.6 & & 25. & 23.238 & & \\
\hline $\mathrm{Sb}$ & & 807 & 0.376 & 441 & 0.309 & 0378 & 0123 & & 0.328 & 0.238 & 0.407 & 0.294 \\
\hline $\mathrm{Sn}$ & 6 & 0 & 0 & 0.006 & & ( & 0.047 & & & 15 & & \\
\hline $\mathrm{Sr}$ & 228.767 & 211.015 & 10.426 & 216.86 & 232.45 & 226.727 & 210.053 & 245.053 & 209.115 & 5226.741 & 190.194 & 199.268 \\
\hline $\mathrm{Ti}$ & & & & & & & & & & & & \\
\hline Cs & & & & & & & & & & & & \\
\hline $\mathrm{Zr}$ & & & & & & & 75 & & & 42 & & 77 \\
\hline $\mathrm{Cr}$ & & & & & & & & & & 76 & & 33 \\
\hline $\mathrm{U}$ & 2 & 2 & (100 & 16.446 & 98 & 49.631 & 14.731 & & 41 & 12.577 & & 17.959 \\
\hline IMMa $\Phi$ & 3.695 & 55 & 291.095 & 557.072 & \begin{tabular}{|l}
515.331 \\
\end{tabular} & 542.63 & \begin{tabular}{|l|l|}
530.309 \\
\end{tabular} & & & 644 & 249 & 486 \\
\hline \multicolumn{13}{|c|}{ Элементы-антибионты (АБ } \\
\hline $\mathrm{B}$ & 76 & обн. & обн. & 3.997 & & 3.445 & 4.625 & 25 & 1 & 373 & 3.835 & 2.973 \\
\hline $\mathrm{Nb}$ & & & & 0.046 & & & & & & .031 & 077 & 0.032 \\
\hline $\mathrm{Sc}$ & & & & & & & & & & & & \\
\hline $\mathrm{Ta}$ & $\mathrm{H}$ & & & $\mathrm{He}$ & & & & & & бн. & & $\mathrm{He}$ \\
\hline $\mathrm{Te}$ & & & & & & & & & & & & \\
\hline $\mathrm{T}$ & & & & & & & & & & 612 & 66 & \\
\hline $\mathrm{W}$ & & & & & & & & & & & & 0.044 \\
\hline $\mathrm{La}$ & & & & & & & & & & 725 & & 0.611 \\
\hline $\mathrm{Ce}$ & & & & & & & & & & & & 28 \\
\hline D & & & & & & & & & & & & \\
\hline$\lambda_{2}$ & & & & & & & & & & & & \\
\hline 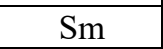 & & & & & & & & & & 51 & & 0.133 \\
\hline $\mathrm{E}$ & & & & & & & & & & 046 & 67 & 0.049 \\
\hline $\mathrm{Gd}$ & 0.215 & & & 0.169 & & & 0.204 & & & .168 & 265 & 0.174 \\
\hline $\mathrm{Tb}$ & & & & & & & 0 & & & .023 & 37 & 0.024 \\
\hline$D$ & & & & & & & & & & & & \\
\hline 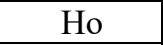 & & & & & & & & & & & & \\
\hline$\Gamma$ & & & & & & & & & & 097 & 33 & 0 14? \\
\hline $\mathrm{Tm}$ & & & & & & & & & & .014 & & 0.017 \\
\hline $\mathrm{Yb}$ & 0.112 & & & 0.093 & & & 0.101 & 0.046 & & 0.086 & 116 & 0.129 \\
\hline $\mathrm{Lu}$ & & & & & & & & & & & & \\
\hline & & & & & & & & & & & & \\
\hline & & & & & & & & & & & 11.516 & \\
\hline Итого & 802.912 & 867.891 & & 874.5 & 832.308 & 822.959 & 818.936 & 004.73 & 772.734 & 894.108 & 917.981 & 876.89 \\
\hline $3 / 45$ & & 15720 & & & & & 2627 & & & & 2894 & 49.18 \\
\hline
\end{tabular}


Таблица 9. Микроэлементы в костном детрите иманайских пещерных медведей, г/m

\begin{tabular}{|c|c|c|c|c|c|c|c|c|c|c|c|c|c|c|c|}
\hline $\begin{array}{c}\text { Эле- } \\
\text { менты }\end{array}$ & $\mathbf{1} / \mathbf{1}$ & $1 / 2$ & 2 & $3 / 1$ & $3 / 2$ & $4 / 1 a$ & $4 / 16$ & $4 / 2$ & 8 & 9 & 10 & \begin{tabular}{|c|}
$(10+11)$ \\
1
\end{tabular} & $\begin{array}{c}(10+11) \\
2\end{array}$ & $12 M$ & 12中 \\
\hline \multicolumn{16}{|c|}{ Элементы-эссенциалы (Э) } \\
\hline $\mathrm{Ag}$ & 0.043 & 0.047 & 0.042 & 0.027 & 0.037 & 0.087 & 0.039 & 0.049 & 0.021 & 0.022 & .049 & 0.039 & 0.04 & 0.049 & 0.041 \\
\hline As & .476 & 0.965 & 1.289 & 1.162 & 2.103 & 1.15 & 0.868 & 1.147 & 2.149 & 2.18 & 2.361 & 1.51 & 1.613 & 2.165 & 1.611 \\
\hline $\mathrm{Bi}$ & .014 & .02 & H. o. & H. o. & 0.019 & 0.006 & H. o. & H. o. & 0.007 & 0.006 & 0.028 & H. o. & 0.055 & 0.013 & .016 \\
\hline $\mathrm{Cd}$ & 2.338 & 1.832 & 1.065 & 0.858 & 1.579 & 1.678 & 0.859 & 1.485 & 3.321 & 2.273 & 3.063 & 1.668 & 1.348 & 3.069 & 413 \\
\hline Mo & 0.42 & 0.539 & 0.131 & 0.269 & 0.411 & 0.224 & 0.232 & 0.259 & 0.291 & 0.394 & 0.511 & 0.143 & 0.122 & 0.857 & 0.255 \\
\hline $\mathrm{Se}$ & 1.849 & 1.386 & 1.44 & 1.055 & 1.285 & 1.275 & 1.14 & 1.337 & 1.654 & 1.451 & 1.207 & 0.971 & 1.29 & 45.03 & 3.103 \\
\hline $\mathrm{Rb}$ & 3.656 & 0.791 & \begin{tabular}{l|}
0.958 \\
\end{tabular} & 0.995 & 5.602 & 0.672 & 0.427 & 0.493 & 2.804 & 0.35 & 3.461 & 0.441 & .608 & 1.215 & 571 \\
\hline $\mathrm{Pb}$ & 1.42 & 0.724 & 0.487 & 0.729 & 2.23 & 0.989 & 0.413 & 0.71 & 1.232 & 0.45 & 2.477 & .33 & 839 & 3.079 & 2.171 \\
\hline $\mathrm{Th}$ & 0.292 & 0.084 & 0.078 & 0.141 & 0.717 & 0.09 & 0.041 & 0.099 & 0.276 & 0.035 & 0.696 & 0.057 & 0.078 & 0.246 & 0.104 \\
\hline $\mathrm{Zn}$ & 550.443 & 484.058 & \begin{tabular}{|l|}
358.474 \\
\end{tabular} & 335.176 & 374.701 & 353.533 & 223.565 & 375.791 & \begin{tabular}{l|l|}
1 & 332.128 \\
\end{tabular} & 475.612 & \begin{tabular}{|l|}
403.26 \\
\end{tabular} & 389.483 & 315.205 & \begin{tabular}{|l|}
363.45 \\
\end{tabular} & 241.553 \\
\hline Сумма & 561.951 & 490.946 & \begin{tabular}{|l|}
363.964 \\
\end{tabular} & 340.412 & 388.684 & 359.704 & |227.584 & \begin{tabular}{|l|}
381.37 \\
\end{tabular} & \begin{tabular}{|l|l|}
743.883 \\
\end{tabular} & 482.773 & 417.113 & \begin{tabular}{|l|l|}
394.642 \\
\end{tabular} & 321.198 & \begin{tabular}{|l|}
419.173 \\
\end{tabular} & 252.838 \\
\hline \multicolumn{16}{|c|}{ Элементы физиологически-активные (ФА) } \\
\hline $\mathrm{Ba}$ & 159.5 & 11.764 & 147.315 & 199.972 & 54.96 & 130.802 & 130.039 & 144.114 & 4229.862 & 187.347 & 178.396 & 174.31 & 169.524 & | 295.914 & 250.5 \\
\hline $\mathrm{V}$ & 13.332 & 10.475 & \begin{tabular}{|l|l|}
7.976 \\
\end{tabular} & 9.581 & 19.302 & 1.403 & 8.052 & 8.365 & 16.237 & 16.237 & 18.825 & 11.011 & 11.239 & 16.857 & 14.067 \\
\hline $\mathrm{Ga}$ & 1.044 & 0.786 & 0.605 & 0.785 & 1.393 & 0.765 & 0.754 & 0.751 & 1.2 & 0.82 & 1.11 & 0.766 & 0.771 & 0.865 & 0.742 \\
\hline $\mathrm{Ge}$ & 0.034 & 0.02 & 0.037 & H. o. & 0.041 & 0.017 & 0.018 & 0.019 & 0.061 & H. o. & H. o. & H. o. & H. o. & H. o. & H. о. \\
\hline Hf & 0.065 & 0.035 & \begin{tabular}{l|}
0.027 \\
\end{tabular} & 0.027 & 006 & 0.049 & 0.02 & 0.07 & 0.129 & 0.042 & 0.519 & 0.074 & & 0.323 & 0.088 \\
\hline $\mathrm{Y}$ & 4.587 & 1.643 & 0.973 & 1.227 & 5.881 & 0.91 & 0.451 & 0.736 & 1.555 & 0.585 & 4.064 & 42 & 24 & 4.869 & 2.403 \\
\hline Co & 2.191 & 1.03 & \begin{tabular}{|l|}
0.931 \\
\end{tabular} & 1.71 & 3.294 & 0.84 & 0.758 & 0.78 & 5.832 & 1.918 & 2.936 & 961 & 02 & 12.518 & 12.887 \\
\hline $\mathrm{Cu}$ & 25.519 & 30.541 & 27.839 & 16.747 & 23.395 & 20.76 & 21.125 & 24.821 & 125.065 & 32.086 & 30.043 & 21.335 & 22.612 & 30.57 & 34.585 \\
\hline $\mathrm{Li}$ & 3.737 & 3.677 & 2.71 & 2.881 & 4.503 & 2.659 & 3.158 & 2.602 & 4.225 & 2.92 & 3.001 & 2.472 & 2.972 & 3.495 & 2.166 \\
\hline $\mathrm{Mn}$ & 198.074 & 100.236 & \begin{tabular}{|l|}
50.194 \\
\end{tabular} & 91.621 & 188.957 & 45.745 & 28.742 & 42.1 & 293.125 & 162.767 & 148.016 & \begin{tabular}{|l|l|}
167.816 \\
\end{tabular} & 53.338 & 677.266 & 329.564 \\
\hline $\mathrm{Ni}$ & 31.789 & 22.103 & \begin{tabular}{|l|}
22.44 \\
\end{tabular} & 24.746 & 36.634 & 17.262 & 17.271 & \begin{tabular}{|l|}
18.759 \\
\end{tabular} & \begin{tabular}{|l|l|}
9 & 52.807 \\
\end{tabular} & 28.158 & 38.126 & 31.38 & 20.381 & \begin{tabular}{|l|}
96.042 \\
\end{tabular} & 55.789 \\
\hline $\mathrm{Sb}$ & 0.214 & 0.167 & \begin{tabular}{|l|}
0.321 \\
\end{tabular} & 0.228 & 0.3 & 0.283 & 0.269 & 0.248 & 0.79 & 0.344 & 0.237 & 452 & 0.446 & \begin{tabular}{|l|}
0.963 \\
\end{tabular} & 0.737 \\
\hline Sn & 0.029 & 0.051 & 0.06 & 0.049 & 0.08 & 0.023 & 0.099 & 0.038 & 0.063 & 0.02 & 0.062 & 0.024 & 0.028 & 0.048 & 0.075 \\
\hline $\mathrm{Sr}$ & 278.925 & 243.35 & \begin{tabular}{|l|}
247.024 \\
\end{tabular} & 366.316 & 18.111 & 255.276 & 256.276 & 241.619 & \begin{tabular}{l|l|}
9 & 344.15 \\
\end{tabular} & 303.972 & 235.859 & 313.226 & 296.911 & \begin{tabular}{|l|}
396.18 \\
\end{tabular} & 333.559 \\
\hline $\mathrm{Ti}$ & 31.561 & 11.841 & \begin{tabular}{|l|}
11.338 \\
\end{tabular} & 15.814 & 51.185 & 14.956 & 8.526 & 13.539 & 34.241 & 11.007 & 84.18 & 12.93 & 312 & 21.025 & 106.948 \\
\hline $\mathrm{Cs}$ & 212 & 0.046 & 0.051 & 0.061 & 0.304 & 0.036 & 0.023 & 0.028 & 0.169 & 0.022 & 0.288 & 27 & 42 & 0.082 & 0.039 \\
\hline $\mathrm{Zr}$ & 11 & 81 & 1.673 & 1.635 & 4.975 & 2.813 & 1.25 & 4.295 & 10.133 & 2.674 & 33.325 & 315 & 38 & 25.631 & 8.679 \\
\hline $\mathrm{Cr}$ & 793 & 7.994 & \begin{tabular}{|l|}
12.057 \\
\end{tabular} & 5.245 & 14.064 & 6.83 & 7.182 & 7.16 & 11.157 & 17.204 & \begin{tabular}{|l|}
18.891 \\
\end{tabular} & 10.619 & 12.946 & \begin{tabular}{|l|}
9.419 \\
\end{tabular} & 10.661 \\
\hline $\mathrm{U}$ & 25.787 & 11.677 & \begin{tabular}{|l|}
19.708 \\
\end{tabular} & 11.768 & 29.489 & 17.146 & 19.351 & 20.391 & 4.956 & 27.883 & 11.938 & 89 & 06 & 31.332 & 32.602 \\
\hline Сумм & .417 & 459.279 & \begin{tabular}{|l|}
553.279 \\
\end{tabular} & 750.413 & 456.928 & 518.575 & \begin{tabular}{|l|}
503.364 \\
\end{tabular} & 530.435 & \begin{tabular}{|l|l|} 
& 1035.76 \\
\end{tabular} & 796.006 & 809.816 & & & & \\
\hline \multicolumn{16}{|c|}{ Элементы-антибионты (АБ) } \\
\hline $\mathrm{B}$ & 12 & 34 & 5.016 & 3.837 & 44 & 3.375 & 4.187 & 4.283 & 5.39 & 3.055 & & & & & . \\
\hline $\mathrm{Nb}$ & 07 & 34 & 0.036 & 0.053 & 0.117 & 0.04 & 0.026 & 0.048 & 0.102 & 0.073 & 0.243 & 067 & 046 & 0.065 & .147 \\
\hline Sc & & 306 & 0.394 & 0.321 & 1.371 & 0.195 & 0.143 & 0.256 & 0.905 & 0.245 & 1.261 & 51 & & 1.156 & 0.553 \\
\hline $\mathrm{Ta}$ & 0.006 & 0.011 & \begin{tabular}{|l|}
0.013 \\
\end{tabular} & & & & 0.008 & 0.008 & 0.008 & & & & & 0.01 & 0.02 \\
\hline $\mathrm{Te}$ & & & & & & & 0.025 & & 0.044 & & 54 & & & & .041 \\
\hline $\mathrm{Tl}$ & 69 & 18 & \begin{tabular}{|l|}
1.348 \\
\end{tabular} & 0.447 & & 0.408 & 0.272 & 0.408 & 1.159 & 0.965 & 1.091 & 03 & 88 & 87 & 1.073 \\
\hline $\mathrm{W}$ & 0.113 & 0.064 & \begin{tabular}{|l|}
0.041 \\
\end{tabular} & 0.112 & 0.127 & 0.051 & 0.048 & 0.057 & 0.132 & 0.136 & 0.37 & 34 & 61 & 0.437 & 0.27 \\
\hline $\mathrm{La}$ & & 0.826 & \begin{tabular}{|l|}
0.514 \\
\end{tabular} & 0.819 & & 0.555 & 0.289 & 0.418 & 1.314 & 0.361 & 3.102 & 218 & & 0.09 & 2.263 \\
\hline $\mathrm{Ce}$ & 95 & 1.089 & \begin{tabular}{|l|}
0.783 \\
\end{tabular} & 1.416 & 6.412 & 0.992 & 0.542 & 0.735 & 2.858 & 0.53 & 5.499 & 389 & & .108 & 2.743 \\
\hline $\operatorname{Pr}$ & & & & 0.185 & & & 0.066 & & 0.303 & 0.069 & 0.775 & 5 & & & 0.36 \\
\hline $\mathrm{Nd}$ & & & \begin{tabular}{|l|}
0.494 \\
\end{tabular} & 0.766 & & 0.482 & 0.267 & & 1.193 & 0.3 & 3.298 & 206 & & & 1.381 \\
\hline $\mathrm{Sm}$ & 0.559 & 0.156 & \begin{tabular}{|l|}
0.107 \\
\end{tabular} & 0.17 & 0.783 & 0.109 & 0.056 & 0.084 & 0.247 & 0.06 & \begin{tabular}{l|l}
0.669 \\
\end{tabular} & 044 & 0.086 & 075 & 0.278 \\
\hline $\mathrm{Eu}$ & 0.135 & 0.045 & \begin{tabular}{|l|}
0.036 \\
\end{tabular} & 0.05 & 0.185 & 0.032 & 0.024 & 0.027 & 0.077 & 0.025 & 0.164 & 0.017 & 32 & 134 & 0.082 \\
\hline $\mathrm{Gd}$ & & & & 0.183 & 0.875 & 0.123 & 0.069 & 0.097 & 0.274 & 0.073 & 0.744 & & & 96 & 0.321 \\
\hline $\mathrm{Tb}$ & & & & & & & & 0.013 & 0.037 & 0.011 & 0.099 & 008 & & & 0.04 \\
\hline Dy & 0.548 & 0.168 & \begin{tabular}{|l|}
0.114 \\
\end{tabular} & 0.149 & 0.712 & 0.104 & 0.055 & 0.082 & 0.211 & 0.058 & 0.601 & 0.037 & 0.073 & 0.114 & 0.234 \\
\hline Ho & 0.115 & 0.036 & 0.023 & 0.032 & 0.145 & 0.02 & 0.012 & 0.018 & 0.043 & 0.013 & 0.114 & 0.009 & 0.017 & 0.122 & 0.057 \\
\hline $\mathrm{Er}$ & 0.318 & 0.113 & 0.068 & 0.093 & 0.415 & 0.072 & 0.034 & 0.052 & 0.117 & 0.042 & 0.323 & 0.029 & 0.049 & 0.144 & 0.156 \\
\hline $\mathrm{Tm}$ & 004 & 0.014 & 0.009 & 0.012 & 0.055 & 0.009 & 0.004 & 0.007 & 0.017 & 0.005 & 0.043 & 0.003 & 0.006 & 0.204 & 0.021 \\
\hline $\mathrm{Yb}$ & 0.248 & 0.077 & 0.052 & 0.067 & 0.326 & 0.061 & 0.033 & 0.04 & 0.098 & 0.03 & 0.234 & 0.023 & 0.045 & 0.11 & 0.139 \\
\hline $\mathrm{Lu}$ & 0.037 & 0.01 & 0.008 & 0.011 & 0.048 & 0.009 & 0.004 & 0.007 & 0.015 & 0.005 & 0.035 & 0.003 & 0.006 & 0.076 & 0.025 \\
\hline $\begin{array}{c}\text { Сумма } \\
\mathrm{Ln}\end{array}$ & 12.389 & 3.641 & 2.478 & 3.981 & 18.211 & 2.713 & 1.465 & 2.042 & 6.804 & 1.582 & 15.70 & 1.082 & 2.062 & 2.611 & 8.10 \\
\hline $\begin{array}{c}\text { Сумма } \\
\text { АБ }\end{array}$ & 22.002 & 8.936 & 9.35 & 88 & 9 & 22 & 74 & 145 & 14.544 & 03 & 823 & 414 & 7.01 & 0.59 & 501 \\
\hline Итого & 1373.37 & 959.161 & 926.593 & 1099.61 & 872.583 & 885.081 & 737.122 & 918.95 & 1394.18 & 1284.88 & 1249.75 & 51192.805 & 980.051 & 2053.16 & 1448.31 \\
\hline Э/АБ & 25.54 & 54.94 & 38.93 & 38.74 & 14.41 & 52.88 & 36.86 & 53.38 & 23.64 & 79.1 & \begin{tabular}{|l|}
18.28 \\
\end{tabular} & 72.89 & 45.82 & \begin{tabular}{|c|}
39.58 \\
\end{tabular} & 17.43 \\
\hline
\end{tabular}


дведей составляют соответственно: $\mathrm{La} / \mathrm{Sc}$ (8-35), (2.24 \pm 0.51$),(2.15 \pm 0.94) ; \mathrm{La} / \mathrm{Th}-(1-$ $2),(6.47 \pm 2.3),(7 \pm 4.79) ; \mathrm{Th} / \mathrm{Sc}-(0.07-0.15)$, $(0.36 \pm 0.1),(0.33 \pm 0.13) ; \mathrm{Th} / \mathrm{U}-(0.02-0.05)$, $(0.005 \pm 0.004),(0.01 \pm 0.02) ; \mathrm{Co} / \mathrm{Th}-(4.7-$ $8.7),(16.16 \pm 12.95),(28.52 \pm 33.18)$. Из приведенных данных следует, что по всем геохимическим модулям костный детрит иманайских пещерных животных кардинально отличается от ископаемых костей плейстоценовых млекопитающих, захороненных во внепещерных обстановках.

Особое место среди микроэлементов в костях занимают лантаноиды, которые приобрели в настоящее время большую популярность в качестве геохимических критериев степени фоссилизации и относительного возраста ископаемого костного детрита (Herwartz et al., 2013). В нашем случае суммарное содержание лантаноидов в костях львов и медведей составляет соответственно $2.792 \pm 1.505$ и $5.657 \pm 5.52$ г/т, что в среднем в 70-140 раз уступает содержанию лантаноидов во внепещерных костях плейтоценовых животных, но в 10-20 тыс. раз превосходит содержание лантаноидов в живых организмах. Последовательность обогащения костей иманайских львов лантаноидами имеет следующий вид: (клык, сесамовидные кости) < позвонки < (ребра, фаланги). Аналогичная последовательность для медвежьих костей: (зубы, клыки, челюсть) < кости метаподия < (череп, бедро, атлант) < (ребро, фаланги).

Тренд нормированных на PAAS (средний постархейский австралийский сланец) концентраций лантаноидов в исследованных костях (рис. 13) демонстрирует их относительное обогащение средними лантаноидами $(\mathrm{Sm}, \mathrm{Eu}, \mathrm{Gd})$ с проявлением, хотя и в несколько завуалированной форме, так называемого тетрадного эффекта (McLennan, 1994). Суть этого эффекта состоит в том, что в цериевой и иттриевой подгруппах лантаноидов в ходе фоссилизации костей сокращается содержание относительно легких элементов, склонных к выщелачиванию, но растет содержание относительно тяжелых элементов, склонных к образованию немигрирующих комплексных соединений. В результате возникает ступенчатая неоднородность распределения элементов с более или менее выраженными скачками концентраций на грани- цах так называемых тетрад: La-Nd (относительный минимум) $\rightarrow$ Pm-Gd (максимум) $\rightarrow$ $\mathrm{Tb}-\mathrm{Ho}$ (минимум) $\rightarrow \mathrm{Er}-\mathrm{Lu}$ (максимум). Считается, что степень реализации тетрадного эффекта зависит от активности грунтовых вод и возраста ископаемых костей - в более древних и более фоссилизированных в условиях обводненных грунтов костях он выражен более отчетливо (Иванова, Никольский, 2015). Анализируя с этих позиций исследуемые пещерные кости, нельзя не прийти к выводу, что кости пещерных животных, несмотря на существенно более низкие концентрации лантаноидов, чем во внепещерных костях, демонстрируют тем не менее отчетливую тенденцию к обогащению средними лантаноидами и некоторые признаки тетрадного эффекта. Причем в львиных костях все это выражено отчетливее.
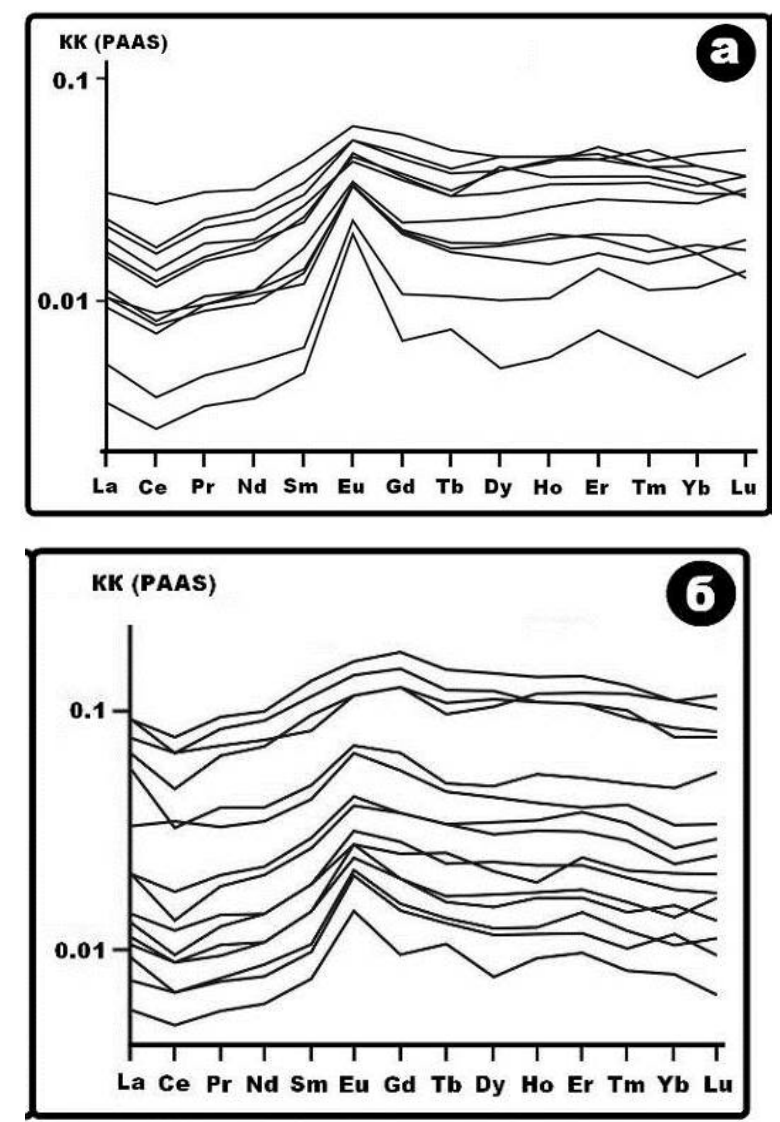

Рис. 13. Тренды нормированных концентраций лантаноидов в иманайском костном детрите пещерных львов (а) и медведей (б)

Суммарная концентрация микроэлементов в исследуемых образцах пещерных костей варьируется для львов в диапазоне 0.841 \pm 0.095 , а для медведей в диапазоне $0.984 \pm$ 0.509 г/т. Последовательности возрастания 
валовых концентраций элементов в анатомических разностях иманайских костей: кости львов - сесамовидные кости < клык < позвонки < ребро; кости медведей - (зубы, череп, ребро $)<($ клык, челюсть, атлант) < (бедро, кости метаподия, фаланги). На генеральной диаграмме обогащения микроэлементами (рис. 14) данные состава костей иманайских львов и медведей накладываются на область состава лишь минимально обогащенных микроэлементами зубов и бивней плейстоценовых животных, захороненных в условиях внепещерных обстановок. Все остальные внепещерные кости в 2-3 раза богаче микроэлементами. Таким образом, обнаруживается, что пещерные ископаемые кости характеризуются значительно меньшим валовым обогащением микроэлементами, чем внепещерные.

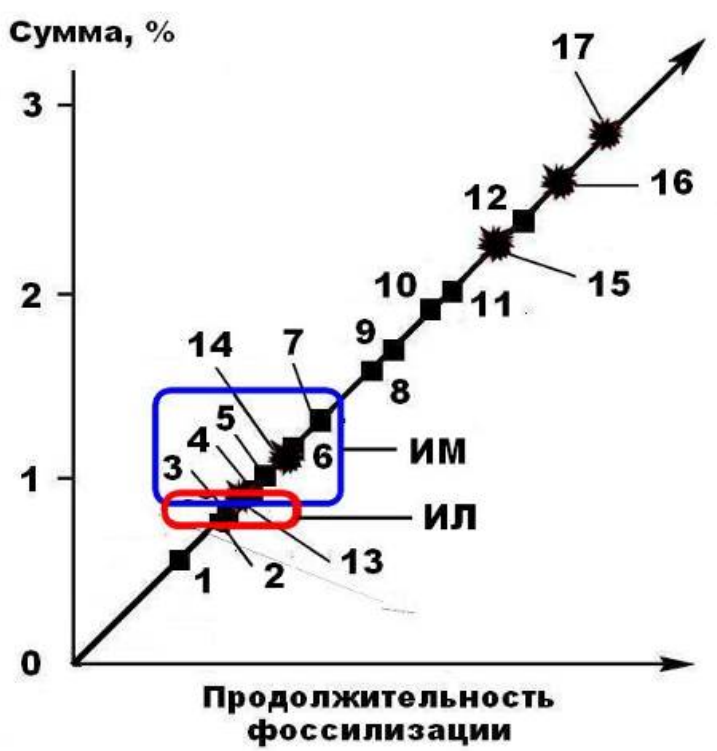

Рис. 14. Суммарное содержание микроэлементов в костном детрите плейстоценовых млекопитаюших из местонахождений в Печорском Приуралье (1-12), со стоянки Заозерье на Среднем Урале (13-17) и из пещеры Иманай на Южном Урале (ИЛ - львы, ИМ - медведи): 1 - мамонт, моляр; 2 -лошадь, резеи; 3 -медведь пещерный, череп; 4, 5-мамонт, зубы; 6, 7, 9 -мамонт, бивень; 8 - носорог иерстистый; 10 мамонт, череп; 11 -мамонт, лопатка; 12 -северный олень, берцовая кость; 13-17 - костный детрит лошадей со стоянки Заозерье, соответственно моляры $(13,14)$, тазовая кость, ребро, пяточная кость

\section{Костный биоапатит}

Кости млекопитающих представляют собой органоминеральный композит, состоящий из органической матрицы (коллагенового белка) и производимого ею минерального вещества, которое в силу происхождения называется биоапатитом. Известно, что в ходе фоссилизации погребенных костей биоапатит подвергается вторичным изменениям, которые могут быть источником важной генетической информации.

На рентгеновских дифрактограммах биоапатита (рис. 15, 16) исследуемых костных образцов регистрируются все важнейшие отражения, характерные для этого минерала, но с разной степенью разрешения, возрастающей в направлении от костей скелета к дентину (зубной кости) и далее зубной эмали.

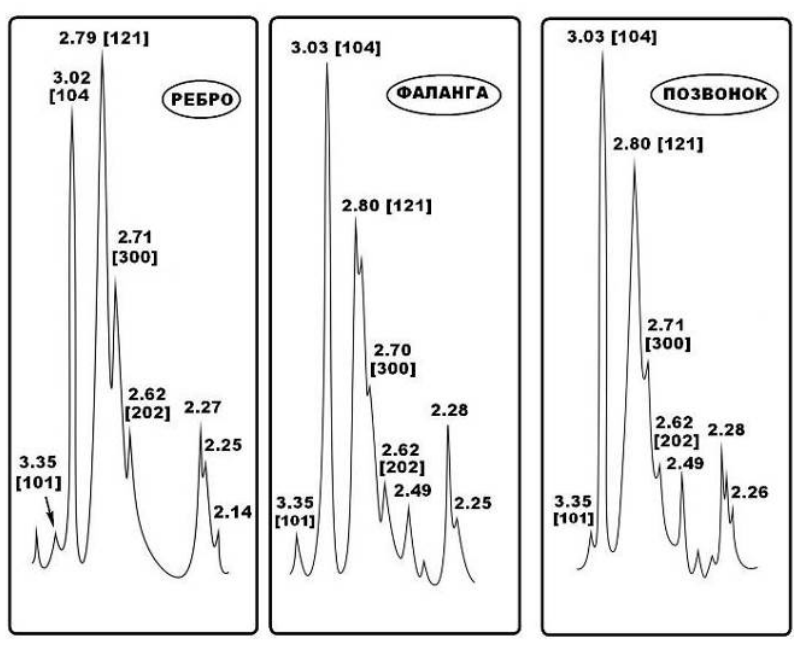

Рис. 15. Типичные рентгеновские дифрактограммы для биоапатита в костях иманайских пещерных львов

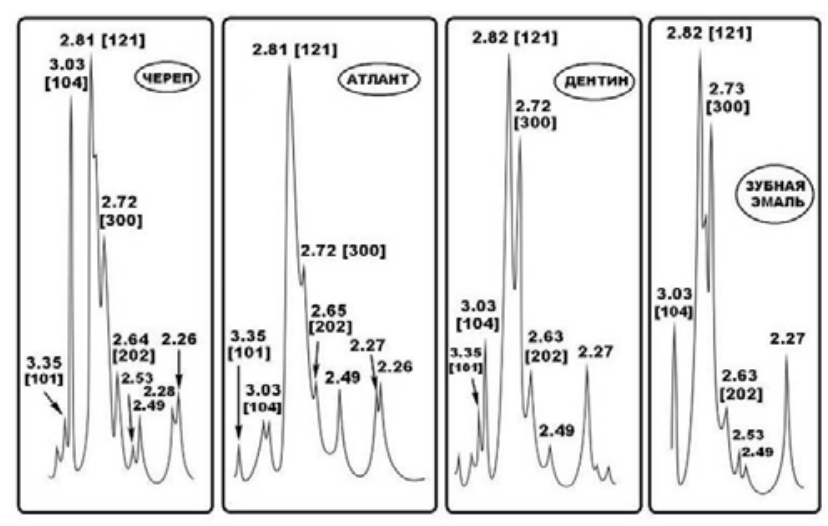

Рис. 16. Типичные рентгеновские дифрактограммы, полученные для биоапатита костей иманайских пещерных медведей 
В нашем случае индекс кристалличности (CI) биоапатита оценивался по отношению интенсивностей $\left(\mathrm{I}_{300}+\mathrm{I}_{202}\right) / \mathrm{I}_{121}$. Рост значений этого индекса свидетельствует об увеличении степени расщепления основного рентгеновского отражения в структуре апатита, а следовательно, указывает на возрастание степени окристаллизованности последнего.

Согласно полученным результатам, средние значения СI для биоапатита в костях львов и медведей составляют соответственно $0.74 \pm 0.05$ и $0.81 \pm 0.17$. В анатомических разностях костей львов эти значения увеличиваются в последовательности: сесамовидные кости $(0.71 \pm 0.04)<$ позвонки $(0.72 \pm$ $0.06)<$ ребра $(0.76 \pm 0.04)<$ клык $(0.8)$. Аналогичный ряд для костей медведей имеет вид: ребро $(0.51)<$ атлант $(0.62)<$ фаланги $(0.71 \pm 0.01)<$ бедро $(0.75)<$ череп $(0.78)<$ зубы и клыки $(0.96 \pm 0.1)$. Эти данные в среднем близки к аналогичным результатам для внепещерных костей плейстоценовых животных, но раза в 1.5 уступают им по зубам и клыкам (Силаев и др., 2019).

Содержание основных ксеноминеральных примесей в исследуемых костях оценивалось по отношению главных отражений в кварце (101) и кальците (104) к основному отражению в биоапатите (121). Для костей пещерных львов и медведей значения «кварцевого» отношения $\mathrm{I}_{101} / \mathrm{I}_{121}$ составляют соответственно $0.02 \pm 0.04$ и $0.13 \pm 0.2$, а значения «кальцитового» $-0.77 \pm 0.45$ и $0.76 \pm 0.65$. Следовательно, костный детрит львов и медведей по-разному обогащен упомянутыми примесями - в костях львов многократно меньше примеси кварца, но больше примеси кальцита.

В ИК спектрах исследуемых костей (рис. $17,18)$ отчетливо регистрируются основные полосы v $v_{3}$ и $v_{4}$ поглощения на $\mathrm{PO}_{4}$-группах, a также полосы $v_{2}-v_{4}$ поглощения на группах $\mathrm{CO}_{3}$, изоморфно замещающих фосфатные анионы в биоапатите. Признаков поглощения на группах $\mathrm{CO}_{3}$, замещающих $\mathrm{OH}-$ группы (валентные анионы), не обнаружено. Следовательно, биоапатит в костях иманайских животных, несмотря на кальцитизацию, является практически нацело карбонатапатитом В-типа.

Степень карбонизации биоапатита в рамках ИКС метода можно оценить отношением интенсивностей поглощения в основных полосах фосфатных и карбонатных групп $\mathrm{I}_{3}\left[\mathrm{PO}_{4}\right] / \mathrm{Iv}_{3}\left[\mathrm{CO}_{3}\right]$. Величина этого отношения для исследованных костей пещерных львов и медведей составила соответственно $2.19 \pm 0.83$ и $2.55 \pm 0.96$, из чего следует, что костный биоапатит иманайских львов карбонизирован на 15-20 \% сильнее, чем медвежий. Из приведенных данных следует также, что по степени карбонизации исследованные кости оказались неоднородными. В группе львиных костей степень карбонизации возрастает в последовательности: клык (3.49) < сесамовидные кости $(3.19 \pm 0.63)<$ позвонки $(1.75 \pm 0.54)<$ ребра $(1.59 \pm 0.4)<$ фаланги (1.58). Аналогичная последовательность для медвежьих костей имеет вид: зубы, клыки $(3.47 \pm 0.64)<$ череп $(3.32)<$ бедро $(2.76)<$ атлант $(2.72)<$ челюсть $(2.56)<$ кости метаподия $(1.88<0.49)<$ фаланги $(1.62 \pm 1.04)<$ ребро (1.36).

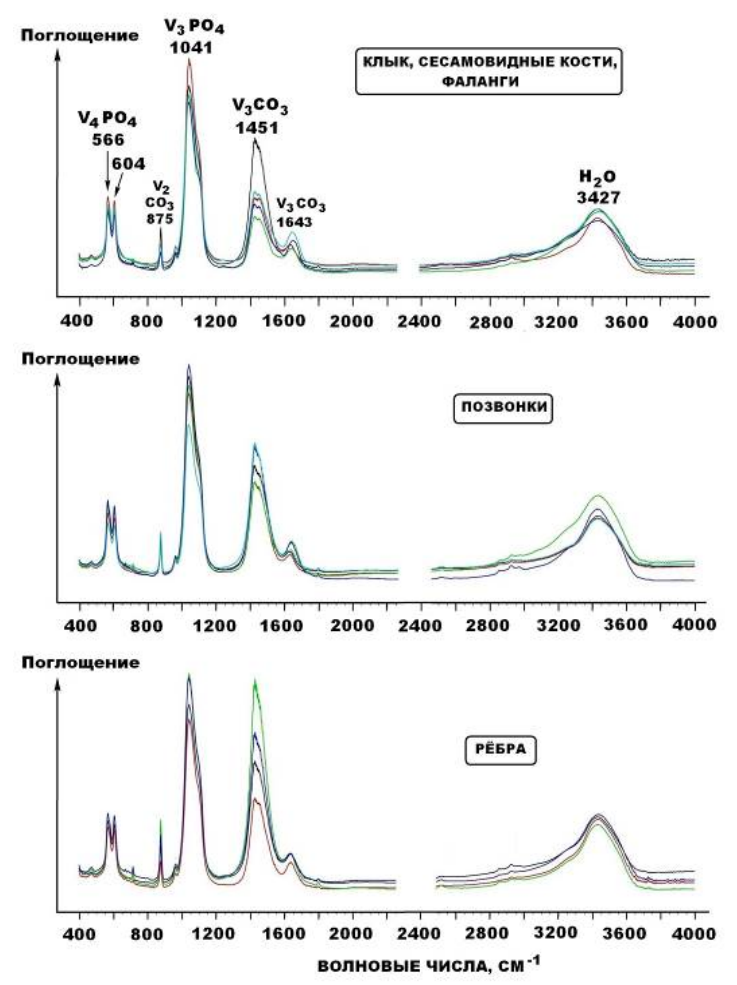

Рис. 17. ИК спектры костей иманайских пещерных львов

Химический состав биоапатита в исследуемых костях определялся рентгеноспектральным микрозондовым методом. Согласно полученным данным, этот минерал характеризуется сложным и притом разным для львов и медведей составом как в катионной, так и 
анионной подрешетках, что хорошо отражают соответствующие эмпирические формулы: кости львов - (Ca9.77-10Zn0-0.14Fe00.12) ${ }_{10}\left[\left(\mathrm{P}_{5.19-5.56} \mathrm{C}_{0.44-0.81}\right)_{6} \mathrm{O}_{24}\right](\mathrm{OH})_{0.83-1.09} \mathrm{Cl}_{0.36-}$ 0.47; кости медведей - (Ca9.88-10 $\mathrm{Sr} 0-0.12) 10\left[\left(\mathrm{P}_{5.14}\right.\right.$ $\left.\left.{ }_{5.55} \mathrm{~S}_{0-0.26} \mathrm{C}_{0.45-0.80}\right)_{6} \mathrm{O}_{24}\right] \quad(\mathrm{OH})_{1.29-1.56} \mathrm{Cl}_{0-0.4}$. Из приведенных формул следует, что иманайские пещерные кости в целом характеризуются аномально высокими значениями атомного отношения $\mathrm{Ca} / \mathrm{P}$, чем они радикально отличаются от костей внепещерных плейстоценовых животных (рис. 19).

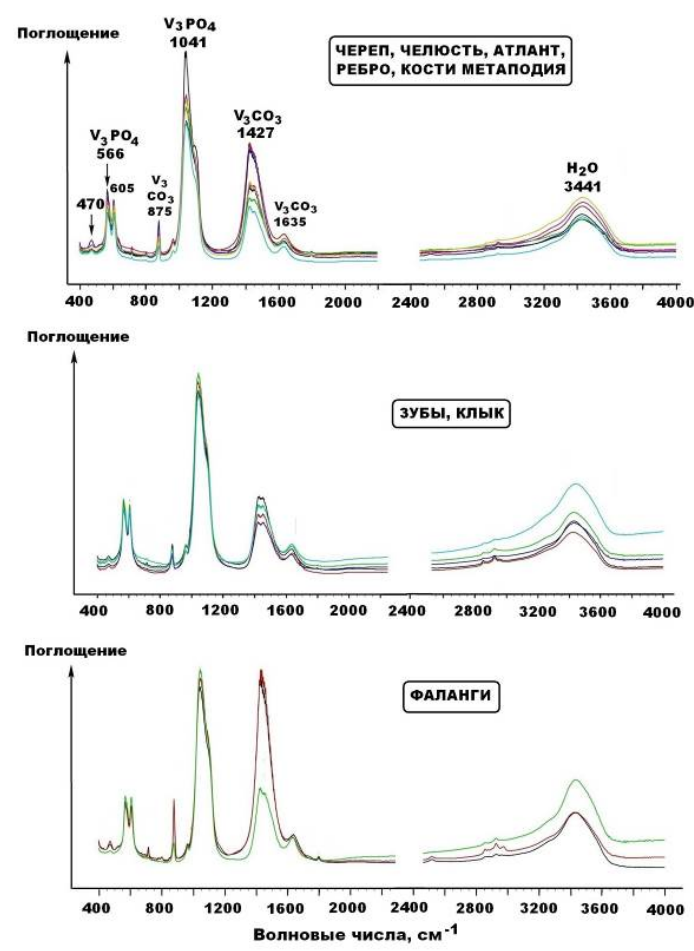

Рис. 18. ИК спектры костей иманайских пещерных медведей

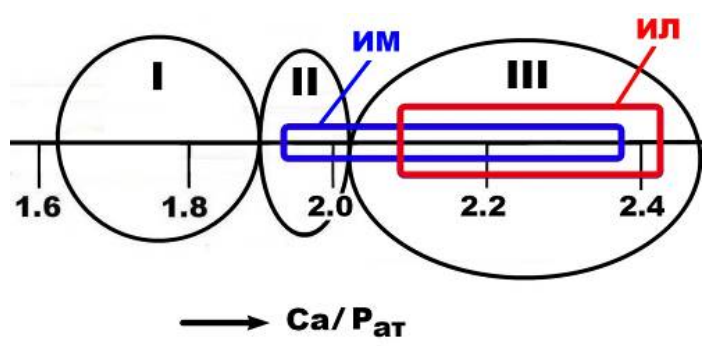

Рис. 19. Вариации коэффициента атомного отношения $C$ Са/P в первичных и слабоизмененных голоченовых костях внепещерного захоронения (I), в измененных плейстоценовых костях внепещерного захоронения (II) и в пещерных кальичнированных костях (III). ИМ и ИЛ - поля значений для костного детрита соответственно медведей и львов из пещеры Иманай
Кроме того, установлено, что биоапатит в костях иманайских львов и медведей системно отличается по структурным примесям: в первых примеси представлены Zn и $\mathrm{Fe}$, а во вторых - Sr и S. Получается, что фоссилизация костей животных происходила не тождественно. Проведенные СЭМ исследования показали, что в биоапатите иманайских костей имеется множество микрометровых включений разнообразных ксеногенных минералов. При этом «львиные» и «медвежьи» парагенезисы таких минералов оказались весьма различными. В костях пещерных львов установлены кварц, циркон, рутил состава ( $\left.\mathrm{Ti} 0.98 \mathrm{~V}_{0.02} \mathrm{O}_{2}\right)$, ильменит (Fe.890.99 $\mathrm{Mn}_{0-0.11} \mathrm{Cu}_{0-0.02}$ )1-1.02(Ti0.95-0.98Al0-003 $\mathrm{V}_{0.01-}$ $0.02 \mathrm{O}_{3}$, ре-дкоземельные ортофосфаты

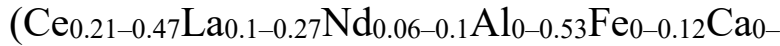
$\left.{ }_{0.07} \mathrm{Cu}_{0.03-0.1} \mathrm{Zn}_{0-0.07}\right)\left[\mathrm{PO}_{4}\right]_{0.93-0.96}$ и н необычно поликомпонентные шпинелиды (Fe0.61$\left.{ }_{0.94} \mathrm{Mg}_{0-0.31} \mathrm{Mn}_{0.02-0.06} \quad \mathrm{Cu}_{0-0.04 \mathrm{Zn}_{0-0.05}}\right)\left(\mathrm{Fe}_{0.89-}\right.$ $\left.{ }_{2} \mathrm{Ti}_{0-0.6} \mathrm{Al}_{0-0.49} \mathrm{~V}_{0-0.02}\right)_{2} \mathrm{O}_{4}$ ) (миналы, мол. \%: магнетит 15-88, ульвит 0-60, герцинит 0-18, магноферрит 0-31, кулсонит 0-1, якобсит 03 , галаксит 0-6, ганит 0-3, купрошпинель $0-$ 4, франклинит 0-5).

В костях пещерных медведей состав микроминерального парагенезиса гораздо более сложный: кварц, циркон, ортоклаз, титанит состава Сa0.99-1.01 (Ti ${ }_{0.72-0.96} \mathrm{Al}_{0.04-0.25} \mathrm{Fe}_{0-0.02} \mathrm{~V}_{0-}$ 0.01) 0.99-1 $\left[\mathrm{SiO}_{4.72-4.96}(\mathrm{OH})_{0.04-0.28}\right]$ (миналы, мол. $\%$ : титанит 71.65-96.47, вьюаньяит 3.5328.35), клиноцоизит $\left(\mathrm{Ca}_{1.97} \mathrm{Cu}_{0.06}\right)_{2.03} \quad\left(\mathrm{Al}_{2.26}\right.$ $\left.\mathrm{Fe}_{0.75}\right)_{3.01}\left[\mathrm{Si}_{3} \mathrm{O}_{11}\right](\mathrm{OH})_{1.09}$, гранаты $\left(\mathrm{Ca}_{2.7-3.01}\right.$

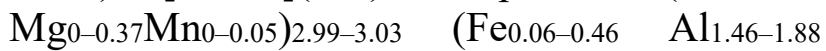
Ti $0.04-0.08)_{2}\left[\mathrm{Si}_{3} \mathrm{O}_{12}\right]$ (миналы, мол. \%: гроссуляр 65.26-84.03, андрадит 5.93-27.11, пироп 0-12.25, спессартин 0-1.66), шпинелиды (Fe0.58-1Mn0-0.02 Cu0-0.04)(Fe1.65-1.79Cr0-0.35Ti0-0.15 $\mathrm{Al}_{0-0.06)} \mathrm{O}_{4}$ (миналы, мол. \%: магнетит 43.582.5 , хромит $0-17.5$, ульвит $0-15$, герцинит $0-3$, якобсит 0-2, купрошпинель $0-4$, франклинит 0-36), поликомпонентные сульфатокарбонаты (бариевые $\left(\mathrm{Ba}_{0.57-0.96} \mathrm{Zn}_{0-0.36} \mathrm{Cu}_{0-0.06}\right.$

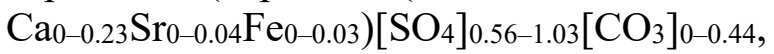
кальциевые $\left(\mathrm{Ca} 0.81 \mathrm{Na}_{0.27} \mathrm{~K}_{0.11}\right)_{1.19}\left[\mathrm{SO}_{4}\right]$, стронциевые $\quad\left(\mathrm{Sr}_{0.51} \mathrm{Zn}_{0.43} \mathrm{Cu}_{0.03} \mathrm{Ca}_{0.01} \mathrm{~K}_{0.02}\right)\left[\mathrm{SO}_{4}\right]_{0.44}$ $\left.\left[\mathrm{CO}_{3}\right]_{0.55}\right)$, оксигидроксиды (Mn0.79-0.88 $\mathrm{Fe}_{0-0.21}$ Ni0_0.06 $\mathrm{Cu} 0-0.03 \mathrm{Zn} 0-0.03 \mathrm{Ba} 0-0.05 \mathrm{Ca} 0-0.07) \mathrm{O}(\mathrm{OH})_{0.86-1}$ и металлические сплавы (железоникелевые

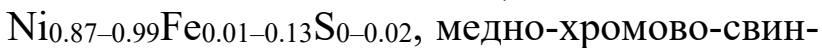


цовые $\mathrm{Pb}_{0.39-0.46} \mathrm{Cr}_{0.38-0.39} \mathrm{Zn}_{0.08-0.11} \mathrm{Cu}_{0.08-0.12}$ и свинцово-оловянные $\mathrm{Sn}_{0.69} \mathrm{~Pb} 0.31$ ).

Таким образом, костный детрит пещерных львов и медведей принципиально различается. В костях львов выявлено 6 минералов и минеральных твердых растворов, относящихся к оксидам, кислородным солям (фосфатам), силикатам, а в костях медведей установлены 13 минералов гораздо более широкого ассортимента: самородные металлы, оксиды, кислородные соли (карбонатсульфаты), силикаты, алюмосиликаты, титаносиликаты.

\section{Органический матрикс}

Исследуемые кости характеризуются аномально низким содержанием Сорг - для пещерных львов оно составляет $1.05 \pm 0.94$, а для медведей $3.57 \pm 2.87$ мас.\% Это примерно на порядок меньше, чем в живых костях, и в 1.5 - 6 раз уступает внепещерным костям плейстоценовых животных. Столь низкое содержание органического углерода в пещерных костях вполне объяснимо. Как известно, при фоссилизации в захороненных костях органический матрикс подвергается не только бактериальному выеданию, но и в еще большей степени окислению и гидролизу (Lindahl, 2000). Понятно, что в условиях пещерных захоронений процесс гидролитического разложения костного коллагена идет особенно быстро вследствие повышенной кислотности внутрипещерных вод.

Физическое присутствие органического вещества в иманайских костях выявлено термическим методом - на кривых нагревания наблюдаются характерные для выгорания органического вещества экзотермические пики. На термограммах львиных костей, как правило, регистрируется единичный экстремум с максимумом при 314 $330^{\circ} \mathrm{C}$, а на термограммах костей медведей часто встречаются двухвершинные кривые нагревания с максимумами при 183-332 и $372-415^{\circ} \mathrm{C}$. В этом случае экстремумы по своему положению примерно отвечают соответственно «углеводно-липидному» и «аминокислотно-белковому» пикам на кривых нагревания относительно хорошо сохранившегося костного коллагена (Смирнов и др., 2009). Кроме того, на кривых нагревания отчетливо проявляется эндотермический пик с максимумом при $739-785^{\circ} \mathrm{C}$, отвечающий диссоциации карбонатов.

Выделение коллагена из исследуемых костей осуществлялось химическим методом деминерализации. Его выход из костных остатков пещерных львов и медведей составил соответственно 0.03-2.9 и 0.5-10.77 мас. $\%$. Полученное органическое вещество варьирует по окраске от светло- до темно-бурого, сохраняя признаки первично-волокнистой текстуры, но львиный коллаген оказался в среднем несколько светлее (рис. 20).

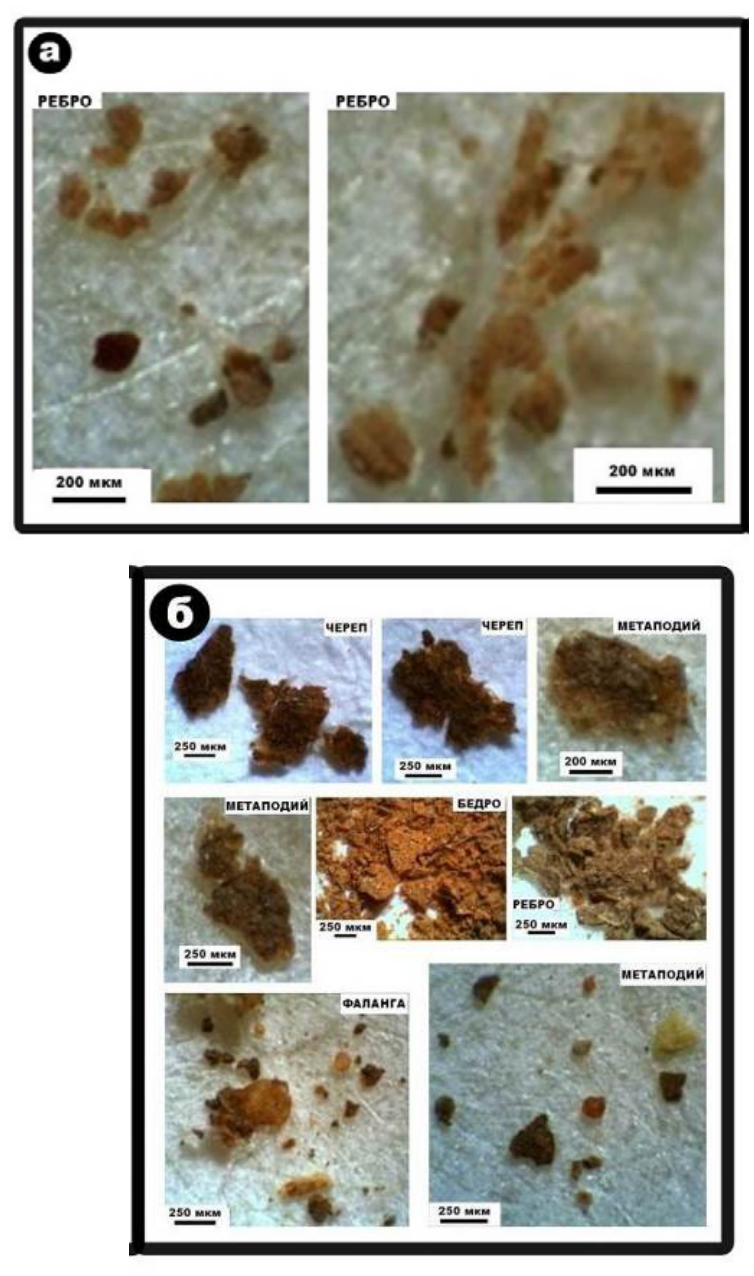

Рис. 20. Внешний вид коллагена, выделенного из иманайских пещерных костей

По валовому химическому составу (табл. 10) костный коллаген львов и медведей в целом аналогичен, хотя в некоторых деталях не совпадает. Так, львиный костный коллаген в отличие от медвежьего содержит примесь $\mathrm{Cu}$ и $\mathrm{Zn}$, но не содержит примеси Ті и Mn. Кроме того, в львином коллагене в два раза 
меньше железа, в три раза меньше калия и в 6-7 раз меньше хлора.

Элементный состав коллагена, определенный методом газовой хроматографии, у львов и медведей несколько различается, коррелируя с отмеченной выше степенью его сохранности в ископаемых костях (мас. \%): львы - C = 35.9-28.4 (32.13 \pm 5.3$), \mathrm{N}=9.3$ $12.5(10.5 \pm 2.26)$; медведи $-\mathrm{C}=40.1-44.3$ (42.23 \pm 2.1$), \mathrm{N}=14.3-15.9(15.29 \pm 0.8)$.

Тем не менее атомное отношение $\mathrm{C} / \mathrm{N}$ в коллагене всех образцов оказалось вполне на уровне приемлемости для изотопных исследований (Ambrose, 1990): львы - $3.71 \pm 0.16$; медведи $-3.49 \pm 0.02$.

\section{Изотопно-геохимическая информация и палеоэкологические реконструкции}

Изотопный состав анализировался во всех образцах последовательно, сначала в костном биоапатите, а затем в выделенном из того же образца коллагене. Полученные результаты (табл. 11) сопоставлялись с аналогичными данными по костным остаткам, захороненным как в пещерных, так и внепещерных обстановках на территории Западной Европы, Европейской части России и Северной Евразии.

По изотопному составу углерода и кисло- рода в биоапатите костный детрит иманайских пещерных львов и медведей в сравнении с внепещерными костными остатками плейстоценовых животных является аномальным, отличаясь сильным изотопным утяжелением по обоим элементам (рис. 21).

При этом кости иманайских животных характеризуются изотопной неоднородностью в ряду остеологических разностей. Так, в ряду львиных костей относительное утяжеление изотопного состава углерода и кислорода происходит в последовательности: ребро $\leftrightarrow$ позвонки $\rightarrow$ сесамовидные кости. Утяжеление изотопного состава углерода и кислорода в биоапатите медведей усиливается в последовательности: (челюсть, зубы, фаланги) $\rightarrow$ (череп, атлант) $\rightarrow$ (кости метаподия, ребро) $\rightarrow$ бедро.

Проведенный сравнительный анализ показал, что иманайские кости по изотопному составу биоапатита, хотя и являются особенными, но при этом по степени изотопного утяжеления не лидируют среди пещерных ориктоценозов.

Например, кости пещерного медведя из Печорского Приуралья и костные остатки западно-европейских пещерных львов и медведей характеризуются гораздо большим изотопным утяжелением как по углероду, так и кислороду.

Таблица 10. Валовый химический состав коллагена, выделенного из костей иманайских пещерных львов (1-4) и медведей (5-16), мас. \%

\begin{tabular}{|c|c|c|c|c|c|c|c|c|c|c|c|c|c|c|c|}
\hline №n/n & № обр. & $\mathrm{SiO}_{2}$ & $\mathrm{TiO}_{2}$ & $\mathbf{A l}_{2} \mathbf{O}_{3}$ & $\mathrm{Fe}_{2} \mathrm{O}_{3}$ & MnO & $\mathrm{CuO}$ & $\mathrm{ZnO}$ & $\mathrm{CaO}$ & $\mathrm{BaO}$ & $\mathrm{K}_{2} \mathrm{O}$ & $\mathrm{P}_{2} \mathrm{O}_{5}$ & $\mathrm{SO}_{3}$ & $\mathbf{C l}$ & Сумма \\
\hline 1 & 492 & 6.62 & H. o. & 0.78 & 0.75 & H. o. & 0.83 & 0.89 & 0.18 & H. o. & H. o. & H. o. & 1.03 & Не обн & 11.08 \\
\hline 2 & $\ll$ & 6.63 & $\ll$ & 1.07 & 0.55 & $\ll$ & 0.62 & 0.61 & 0.53 & $\ll$ & $\ll$ & $\ll$ & 1.92 & 0.26 & 12.19 \\
\hline 3 & 2871 & 0.35 & « & H. o. & H. o. & $\ll$ & H. o. & H. o. & H. o. & « & « & « & « & H. o. & 0.35 \\
\hline 4 & 2879 & 3.59 & $\ll$ & 0.76 & $\ll$ & 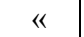 & $\ll$ & $\ll$ & $\ll$ & $\ll$ & 0.31 & $\ll$ & $\ll$ & 0.17 & 4.83 \\
\hline \multicolumn{2}{|c|}{ Среднее } & 4.3 & \multirow{2}{*}{0} & 0.65 & 0.33 & \multirow{2}{*}{0} & 0.36 & 0.38 & 0.18 & \multirow{2}{*}{0} & 0.08 & \multirow{2}{*}{0} & 0.74 & 0.11 & 7.11 \\
\hline \multicolumn{2}{|c|}{ СКО } & 2.99 & & 0.46 & 0.38 & & 0.43 & 0.45 & 0.25 & & 0.15 & & 0.93 & 0.13 & 5.55 \\
\hline 5 & $1 / 2$ & 0.36 & $\ll$ & H. o. & 0.75 & $\ll$ & $\ll$ & $\ll$ & $\ll$ & $\ll$ & H. o. & $\ll$ & $\ll$ & H. o. & 1.11 \\
\hline 6 & $\ll$ & 3.76 & $\ll$ & 0.74 & 0.78 & $\ll$ & $\ll$ & $\ll$ & $\ll$ & $\ll$ & 0.36 & $\ll$ & 0.67 & & 6.31 \\
\hline 7 & 2 & H. o. & 0.33 & H. o. & H. o. & $\ll$ & $\ll$ & $\ll$ & $\ll$ & $\ll$ & 0.55 & $\ll$ & 1.29 & 0.35 & 2.52 \\
\hline 8 & $\ll$ & 0.49 & H. o. & $\ll$ & $\ll$ & $\ll$ & $\ll$ & $\ll$ & $\ll$ & $\ll$ & H. o. & $\ll$ & 0.4 & 0.84 & 1.73 \\
\hline 9 & $\ll$ & 0.94 & $\ll$ & $\ll$ & 0.52 & $\ll$ & $\ll$ & $\ll$ & $\ll$ & $\ll$ & $\ll$ & $\ll$ & H. o. & 0.94 & 2.4 \\
\hline 10 & $(10+11) / 1$ & 2.38 & $\ll$ & 0.5 & H. o. & $\ll$ & $\ll$ & $\ll$ & 0.71 & $\ll$ & 1.08 & 0.69 & 1.43 & 0.18 & 6.97 \\
\hline 11 & $\ll$ & 2.68 & $\ll$ & 0.47 & 0.34 & $\ll$ & $\ll$ & $\ll$ & 0.64 & $\ll$ & H. o. & 0.46 & 1.41 & 0.15 & 6.15 \\
\hline 12 & $\ll$ & 3.08 & $\ll$ & 0.58 & H. о.. & $\ll$ & $\ll$ & $\ll$ & 0.54 & $\ll$ & $\ll$ & 0.67 & 1.91 & 0.18 & 6.96 \\
\hline 13 & $\ll$ & 0.31 & $\ll$ & H. o. & $\ll$ & $\ll$ & $\ll$ & $\ll$ & H. o. & $\ll$ & $\ll$ & H. o. & 0.79 & 1.01 & 2.11 \\
\hline 14 & $\ll$ & 9.46 & $\ll$ & 0.99 & 1.95 & \begin{tabular}{|l|}
0.41 \\
\end{tabular} & $\ll$ & $\ll$ & $\ll$ & $\ll$ & 0.5 & $\ll$ & H. o. & 0.77 & 14.08 \\
\hline 15 & $\ll$ & 6.59 & $\ll$ & 1.37 & 1.19 & H. o. & $\ll$ & $\ll$ & 0.96 & $\ll$ & H. o. & 0.53 & 0.96 & 2.77 & 14.37 \\
\hline 16 & $\ll$ & 10.75 & $\ll$ & 2.2 & 2.17 & $\ll$ & $\ll$ & $\ll$ & 0.46 & $\ll$ & 0.61 & H. o. & 0.46 & 1.18 & 17.83 \\
\hline \multicolumn{2}{|c|}{ Среднее } & 3.4 & 0.03 & 0.57 & 0.64 & \begin{tabular}{|l|}
0.03 \\
\end{tabular} & \multirow[b]{2}{*}{0} & & 0.28 & & 0.26 & 0.2 & 0.78 & 0.7 & 6.88 \\
\hline & $\overline{\mathrm{CKO}}$ & 3.66 & 0.09 & 0.68 & 0.77 & \begin{tabular}{|l|}
0.12 \\
\end{tabular} & & & 0.36 & & 0.36 & 0.29 & 0.64 & 0.78 & 5.64 \\
\hline
\end{tabular}


Таблица 11. Изотопные характеристики костного детрита иманайских пещерных львов (1-13) и медведей (14-37), \%о

\begin{tabular}{|c|c|c|c|c|c|c|}
\hline \multirow{2}{*}{$\begin{array}{l}\text { № } \\
\text { II/II }\end{array}$} & \multirow[t]{2}{*}{ № обр. } & \multirow[t]{2}{*}{ Остеология } & \multicolumn{2}{|c|}{ Биоапатит } & \multicolumn{2}{|l|}{ Коллаген } \\
\hline & & & $\delta^{13} \mathrm{C}_{\mathrm{PDB}}$ & $\delta^{18} O_{\text {smow }}$ & $\delta^{13} \mathrm{CPDB}$ & $\delta^{15} N_{\text {Air }}$ \\
\hline 1 & 492 & Позвонок & -7.11 & 21.25 & -24.51 & 9.1 \\
\hline 2 & 622 & $\ll$ & -8.86 & 20.65 & -20.7 & 6.1 \\
\hline 3 & 823 & « & -7.98 & 21.14 & -20.0 & 7.5 \\
\hline 4 & 2847 & « & -7.69 & 22.62 & -22.42 & 6.8 \\
\hline 5 & 2869 & $\ll$ & -6.96 & 21.62 & -24.09 & 8.3 \\
\hline 6 & 2875 & 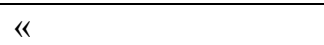 & -7.52 & 19.74 & -25.6 & 7.7 \\
\hline 7 & 2411 & Ребро & -8.36 & 21.43 & \begin{tabular}{|l|}
-19.9 \\
\end{tabular} & 7.1 \\
\hline 8 & 2803 & « & -7.51 & 20.08 & -19.5 & 8.2 \\
\hline 9 & 2871 & « & -8.24 & 21.46 & -25.73 & 8.1 \\
\hline 10 & 2987 & Сесамовидная кость & -6.95 & 19.84 & -22.7 & 6.6 \\
\hline 11 & 3111 & 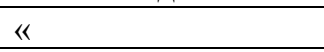 & -6.14 & 21.06 & -19.9 & 7.1 \\
\hline 12 & 3046 & 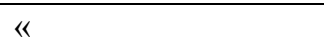 & -8.87 & 19.57 & -22.36 & 9.6 \\
\hline 13 & 2974 & Фаланга & -8.11 & 20.68 & -20.8 & 10.1 \\
\hline \multicolumn{3}{|c|}{ Статистика } & $-7.8 \pm 0.82$ & $20.77 \pm 0.91$ & $-22.12 \pm 2.28$ & $7.87 \pm 1.19$ \\
\hline 14 & 7 & Премоляр & -6.66 & 21.77 & \multirow{3}{*}{\multicolumn{2}{|c|}{ Не опр. }} \\
\hline 15 & $(10+11) / 2$ & Зуб & -8.65 & 20.6 & & \\
\hline 16 & 11 & Премоляр & -7.12 & 21.35 & & \\
\hline 17 & $4 / 1 \mathrm{a}$ & Дентин & -9.41 & 19.94 & -19.6 & .5 \\
\hline 18 & $4 / 16$ & Зубная эмаль & -9.78 & 20.32 & \multicolumn{2}{|l|}{ Не опр. } \\
\hline 19 & $4 / 2$ & Клык & -9.48 & 17.98 & -19.6 & .6 \\
\hline 20 & 9 & « & -9.3 & 16.88 & \multicolumn{2}{|c|}{ Не опр. } \\
\hline 21 & 8 & Бедренная кость & -5.07 & 22.02 & -20.8 & 4.3 \\
\hline 22 & 9 & « & -3.38 & 28.01 & -20.2 & 5.6 \\
\hline 23 & $8+9$ & « & -8.64 & 21.41 & -28.72 & 2.9 \\
\hline 24 & 2 & Кость метаподия & -6.64 & 21.77 & -25.61 & 7.2 \\
\hline 25 & 2 & « & -6.64 & 21.78 & -22.68 & 8.12 \\
\hline 26 & 5 & « & 0.02 & 32.41 & -21.1 & 4.8 \\
\hline 27 & $12 \mathrm{M}$ & 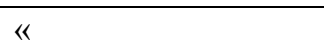 & -8.65 & 20.6 & -24.92 & 6.6 \\
\hline 28 & $12 \mathrm{M}$ & $\ll$ & -8.95 & 19.97 & -20.4 & 4.9 \\
\hline 29 & $1 / 1$ & Фаланга & -10.84 & 19.07 & -23.66 & 5.7 \\
\hline 30 & 10 & 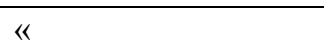 & -8.67 & 22.43 & -23.3 & 3.3 \\
\hline 31 & 10 & 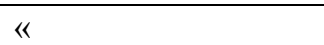 & -7.67 & 21.01 & -22.8 & 3.9 \\
\hline 32 & $12 \phi$ & « & -8.95 & 19.97 & -20.4 & 4.9 \\
\hline 33 & $12 \phi$ & 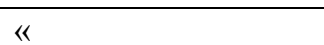 & -8.67 & 22.43 & -23.1 & 5.9 \\
\hline 34 & $1 / 2$ & Череп & -7.36 & 20.07 & -23.13 & 5.9 \\
\hline 35 & $(10+11) / 1$ & Челюсть & -9.34 & 19.89 & -24.92 & 5.2 \\
\hline 36 & $3 / 1$ & Атлант & -7.97 & 20.73 & -19.3 & 3.2 \\
\hline 37 & $3 / 2$ & Ребро & -6.17 & 22.39 & -20.84 & 6.1 \\
\hline \multicolumn{3}{|c|}{ Статистика } & $-7.62 \pm 2.36$ & $21.5 \pm 3.01$ & $-22.51 \pm 2.41$ & $5.14 \pm 1.42$ \\
\hline
\end{tabular}

Таким образом, в ходе проведенных исследований установлен факт системного изотопного утяжеления углерода и кислорода в биоапатите пещерного костного детрита в сравнении с биоапатитом во внепещерных костных остатках. Очевидно, что такая изотопно-геохимическая особенность пещерных костей обусловлена их кальцитизацией под воздействием углекислотных вод, образующихся за счет карстующихся морских карбонатных пород. Именно возрастанию степени эпигенетической кальцитизации костей за счет вещества осадочных карбонатных пород и соответствует показанный стрелкой генеральный тренд согласованного изотопного утяжеления углерода и кислорода в пещерных костях на рис. 21. Схематическое уравнение такого диспропорционирования имеет следующий вид: $2 \mathrm{H}^{12,13} \mathrm{CO}_{3}^{-}+\mathrm{Ca}^{2+}=$ $\mathrm{Ca}^{13} \mathrm{CO}_{3} \downarrow+\mathrm{H}_{2} \mathrm{O}+{ }^{12} \mathrm{CO}_{2} \uparrow+\mathrm{H}_{2} \mathrm{O}$.

Изотопный состав коллагена в костях иманайских пещерных львов и медведей рассмотрен на фоне аналогичных данных по костному коллагену, волосам и коже плей- 
стоценовых и современных млекопитающих. На соответствующей диаграмме (рис. 22) поля данных по иманайским животным занимают вполне закономерные места. Поле данных по иманайским львам совмещается с полями хищников, а поле для иманайских медведей тяготеет к полям преимущественно растительноядных животных, в частности современных бурых медведей.

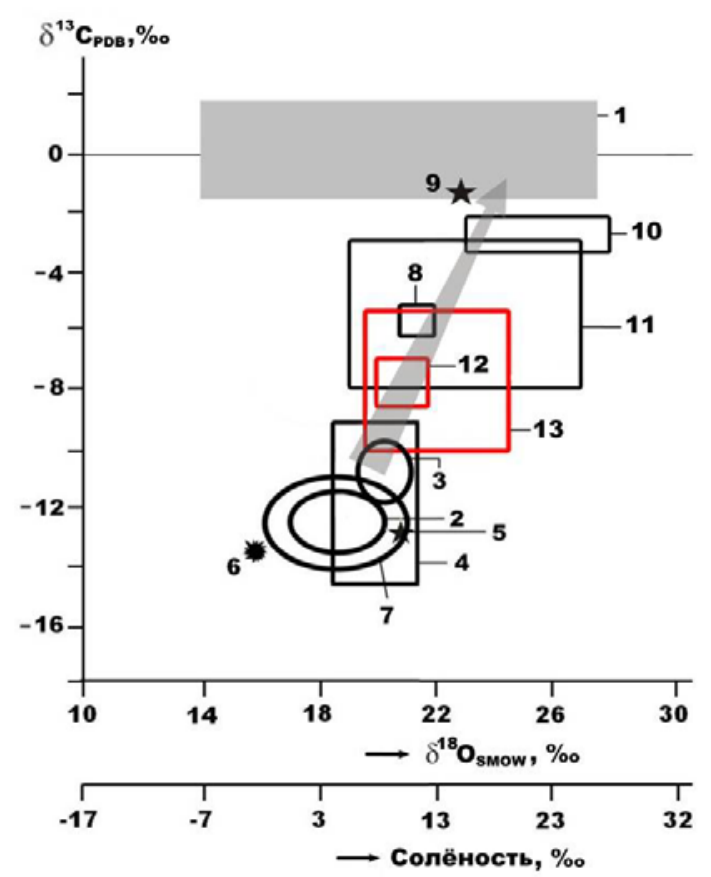

Рис. 21. Изотопный состав биоапатита в ископаемых костях плейстоценовых млекопитающих на фоне морских карбонатных пород: 1 -карбонатолиты; 2 -мамонтовая фауна Западной Евponbl (Tutken et al., 2007); 3 -мамонтовая фауна Печорского Приуралья (Silaev et al., 2017); 4, 5 соответственно мамонтовая фауна и неоплейстоценовый бурый медведь Омского Прииртышья (коллекичия А. А. Бондарева); 6 - пещчерная гиена с Южного Прибайкалья (обр. от Д. В. Кобылкина); 7 - предголоченовые таймырские мамонты (обр. от Г. В. Шнейдера и Д. Н. Костина); 8, 9 - кости пещчерного медведя с Печорского Приуралья с разной степенью кальцичтизации; 10, 11 - соответственно пещуерные львы и медведи Западной Европь (Tutken et al., 2007); 12, 13 - костный детрит соответственно львов и медведей из пещуеры Иманай. Шкала солености водыл построена по даннылм, вычисленным по уравнению В. Н. Кулешова (Кулешов, Гаврилов, 2001). Стрелкой показан генеральный тренд изотопного утяжеления углерода и кислорода при переходе от ископаемьх костей внепещуерного захоронения к пещчерным костным остаткам
При этом полученные по коллагену иманайских костей изотопные данные свидетельствуют об обитании и львов, и медведей в условиях ландшафтов, переходных от лесов к лесостепям с преобладанием растений с $\mathrm{C}_{3}$-типом фотосинтеза ${ }^{7}$ (большинство растений в зоне прохладного и умеренно влажного климата). Все это вполне соответствует геологическим палеоландшафтным реконструкциям на территорию Южного Урала в конце неоплейстоцена.

Особое значение имеет сравнение полученных нами «коллагеновых» изотопных данных по иманайским костным остаткам с данными Г. Бошрена с соавторами для доLGM (50-25 тыс. лет назад) и пост-LGM пещерных львов и медведей Западной Европы (Bocherens et al., 2011). На рис. 22 эти данные показаны после проведенной нами их статистической обработки. В сравнении с результатами по иманайской пещере все поля изотопного состава костного коллагена западно-европейских пещерных львов и медведей сдвинуты в область более изотопнотяжелого углерода, что отвечает переходу от лесостепных и лугово-степных ландшафтов преимущественно с растениями С $\mathrm{C}_{3}$-типа к саваннам с растениями САМ-типа ${ }^{8}$. При этом обнаруживается, что качество диеты до-LGM популяции западно-европейских пещерных львов вполне сопоставимо с качеством питания иманайских пещерных львов, а вот качество диеты пост-LGM популяции пещерных львов в Западной Европе резко снизилось. Последнее выглядит вполне объяснимо, если учесть постледниковое вымирание мегафауны, служившей пищевой базой для крупных хищников в течение почти всего плейстоцена.

Значительный интерес представляет изотопная реконструкция пищевой цепи пещерных львов. Как известно, в основе таких реконструкций лежат уже хорошо обоснованные сдвиги в изотопном составе углерода и азота при переходе по трофическим цепям от растительноядных животных к хищникам (De Niro, 1985; Bocherens, Drucker, 2003).

\footnotetext{
7 Тип фиксации углерода в рамках цикла Мелвина Кельвина: большинство растений в условиях холодного и умеренно-тёплого влажного климата.

${ }^{8}$ Фотосинтез по типу толстянковых растений: умереннотеплые, засушливые области.
} 
Согласно выводу Г. Бошрена, основной пищевой жертвой до-LGM популяции западноевропейских пещерных львов был молодняк пещерных медведей. Проведенные нами расчеты на основании данных Г. Бошрена вполне подтвердили этот вывод (правая стрелка на рис. 22). Аналогичные расчеты с использованием изотопных данных по иманайским пещерным львам показывают, что их пищевой жертвой являлись не пещерные медведи, а с достаточно большой вероятностью шерстистые носороги (левая стрелка на рис. 22). Такой вывод не является особенно оригинальным для неоплейстоцена. Молодь шерстистых носорогов и даже шерстистых мамонтов достаточно часто рассматривается в качестве типичной пищевой жертвы пещерных львов, в частности на территориях Аляски и Северной Евразии (Guthrie, 1968; Turner, 2009; Stuart, Lister, 2011). Хотя, конечно, в случае с иманайскими львами нельзя исключать и таких пищевых жертв, как северный олень и лошади.

В целом, судя по изотопному составу коллагенового углерода и азота, неоплейстоценовые пещерные медведи как в Западной Европе, так и на Южном Урале, были растительноядными животными и вполне могли оказаться (по версии Г. Бошрена) пищей для хищных пещерных львов, если бы, конечно, пересекались с ними по жизни. Однако при этом львы вовсе не были «ужасными хищниками» ни во времена своего существования, ни в проекции на современность. Например, для неоплейстоцена Западной Европы трофическая цепь реконструирована в следующем виде: (растительноядные животные, включая пещерного медведя) $\rightarrow$ бурый медведь $\rightarrow$ рысь $\rightarrow$ лисица $\rightarrow$ пещерный лев $\rightarrow$ волк $\rightarrow$ росомаха $\rightarrow$ пещерная гиена (Bocherens et al., 2011; Bocherens, 2019).

В рамках этой реконструкции пещерный лев находится лишь в средине пищевой цепи, чему соответствуют конкретные изотопные данные как по Западной Европе, так и Евразии (рис. 22). Например, пещерная гиена из Южного Прибайкалья, судя по ее исследованному нами костному коллагену, была более продвинутым хищником, чем евразийские пещерные львы, практически ничем в этом смысле не отличаясь от западноевропейских пещерных гиен.

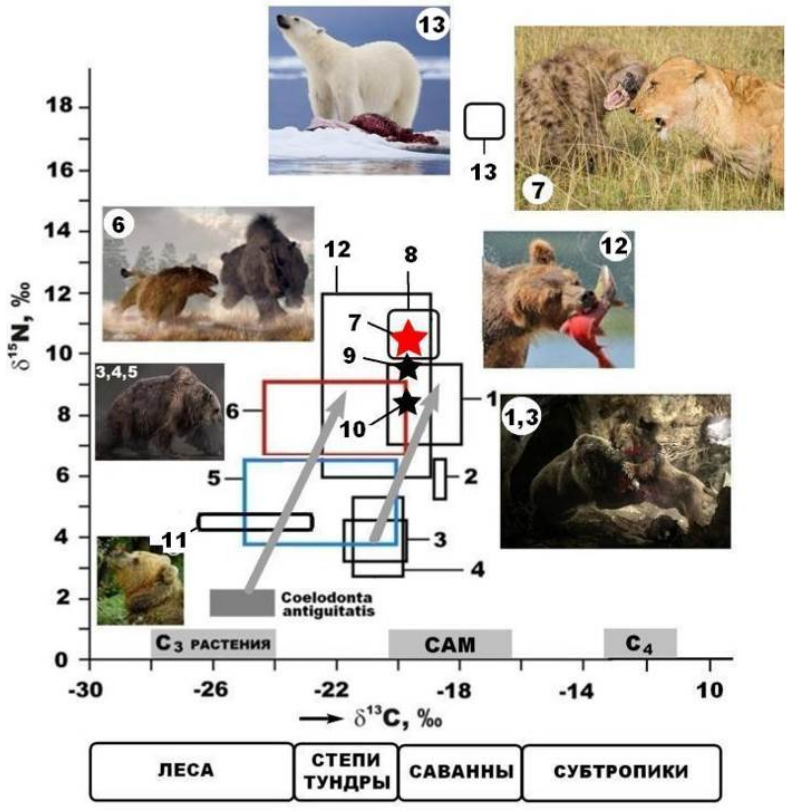

Рис. 22. Изотопный состав костного коллагена, волос и кожи плейстоценовых и современных млекопитаюших: 1, 3 и 2, 4 - соответственно до-LGM и пост-LGM популяциии пещуерных львов и медведей Западной Eвропь (Bocherens et al., 2011); 5, 6 -соответственно львы и медведи из пещеры Иманай; 7 - пещерная гиена с Южного Прибайкалья (обр. от Д. В Кобылкина); 8-10соответственно пещерная гиена, ископаемые волк и росомаха Западной Европь (Bocherens, 2019); 11 - современные таежные бурые медведи (волосы и кожа); 12 - современные камчатские бурые медведи (волосы и кожа); 13 -современные белье медведи (волосы и кожа). Шкала ландшафтов показана по Г. Бошрену и Д. Дракер (Bocherens, Drucker, 2003)

Как показали проведенные нами исследования, пещерные львы по изотопной диете статистически уступали даже некоторым современным бурым медведям, а именно камчатским, не говоря уже о белом медведе, вероятно, величайшем хищнике кайнозоя. Правда, следует учесть, что значительную долю пищи камчатского бурого медведя составляет тихоокеанская рыба, а рацион питания белого медведя и вовсе состоит из океанской рыбы и зверя, что весьма значительно утяжеляет изотопный состав органического азота. Потреблением рыбы, кстати, можно объяснить и недавно выявленные факты изотопного утяжеления азота в костном коллагене некоторых плейстоценовых пещерных медведей в Западной Европе (Bocherens, Drucker, 2019). 


\section{Присутствие древних людей в пешере Иманай}

В ходе раскопок в пещере Иманай были обнаружены многочисленные артефакты, диагностированные археологами как каменная индустрия мустьерской эпохи (среднего палеолита), приписываемая поздним неандертальцам. Кроме того, в черном материале из базального горизонта № 12 нами были обнаружены частицы, очень похожие на частицы древесного угля, который может иметь отношение к древним кострищам. Как известно, в настоящее время в качестве признаков таких кострищ археологами рассматриваются «красные глины», «обгоревшие камни или породы», «обугленные кости», «кремни со следами обработки огнем», «зольные пятна», «древесный уголь» (James, 1989; Амирханов и др., 2013). Из этого списка наиболее приемлемым признаком древних кострищ являются, разумеется, частицы древесного угля, но их диагностика требует использования специальной аналитики.

В нашем случае в качестве такой аналитики был выбран метод КР спектроскопии, которым обычно и диагностируют углеродистые вещества (Силаев и др., 2013). Полученные от черных частиц из Иманайской пещеры и частиц современного древесного угля, образовавшегося в результате сгорания древесины на одном из действующих вулканов Курильской островной гряды, спектры были отфильтрованы от сопутствующей люминесценции. После этого в спектрах обнаружились две рамановские полосы - D (1340 и $\left.1374 \mathrm{~cm}^{-1}\right)$ и $\mathrm{G}\left(1594\right.$ и $\left.1606 \mathrm{~cm}^{-1}\right)$ - с харак- теристиками, отвечающими неметаморфизованному углистому веществу растительного происхождения (рис. 23). Таким образом, обнаруженные в базальном горизонте элювиальных грунтов в иманайской пещере углеродистые частицы оказались именно частицами древесного угля, указывая тем самым на древние кострища и подтверждая факт обитания в пещере Иманай неоплейстоценовых людей. Уже выдвинуты несколько версий использования пещеры Иманай неандертальцами (Паршукова, 2016): в качестве жилища, святилища для отправления культов, ловушки для промысловых животных (например, пещерного медведя), «холодильника» для сохранения охотничьих припасов. В принципе способность палеоантропов к такому социально сложному поведению уже давно не вызывает сомнений (Вишняцкий, 2010; Формозов, 2019), но для конкретного решения этого вопроса в отношении иманайской пещеры необходимо продолжение раскопок с нацеленностью на поиски антропогенных костных останков и последующее их мультидисциплинарное исследование.

Факт обнаружения признаков обитания людей в пещере Иманай далеко (400-500 км) за пределами ареала распространения поздних неандертальцев на территории Западной Европы и Южной Евразии (рис. 24) является сильным подтверждением теории начавшейся примерно 50-40 тыс. лет назад необратимой миграции неандертальцев на север вследствие, прежде всего, изменения климата. В ходе такой миграции Южный Урал вовсе не являлся крайним рубежом. На это ука-

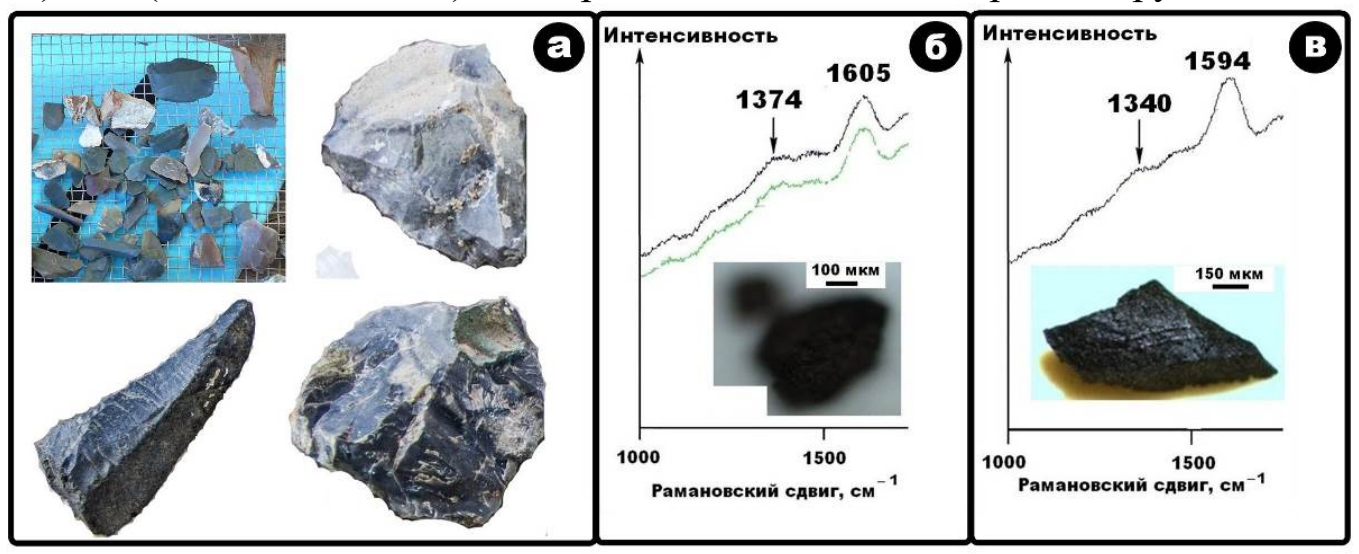

Рис. 23. Орудия культуры мустье (средний палеолит), Иманай (а) и частиџы древесного угля из пещеры Иманай (б) и с современного вулкана Курильской островной гряды (в) 
зывает комплекс данных, полученных П.Ю. Павловым при раскопках стоянки начала верхнего палеолита Заозерье (Силаев и др., 2019). Более того, обнаружение П.Ю. Павловым на расположенной гораздо севернее стоянке Бызовой многочисленных артефактов, связанных с жизнью и деятельностью палеоантропов (Slimak et al., 2011), показывает, что уже к середине каргинского интерстадиала неандертальцы практически достигли Полярного круга, а возможно, и выходили непосредственно на побережье Арктического океана.

Справедливости ради следует отметить, что каргинский интерстадиал был временем больших миграций на север не только неандертальцев, но и людей современного типа. На последнее, в частности, указывает находка костных останков усть-ишимского человека на территории Омского Прииртышья (Силаев и др., 2017). Местонахождение устьишимской кости - на $57^{\circ}$ с. ш., т. е. на 1500 2000 км севернее недавней находки современника усть-ишимского человека в пещере Бачо Киро на территории современной Болгарии (Hublin et al., 2020), что считается более естественным местом обитания людей современного типа в позднем палеолите.

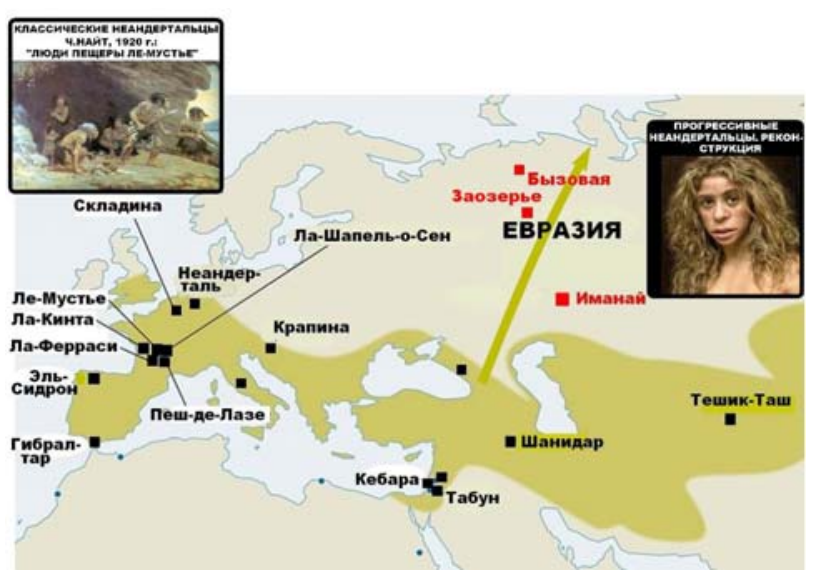

Рис. 24. Некоторые стоянки поздних неандертальиев в Европейской части России на фоне ареала их традииионного распространения по территории Западной Европы и Южной Евразии (показан буроватым иветом). Стрелка направление миграции неандертальщев

Тем не менее следы пребывания современников усть-ишимского человека установлены и на Таймыре - на $72^{\circ}$ с. ш., что, действительно, свидетельствует о широком заселении Арктики людьми современного типа сразу после ранневалдайского оледенения (Pitulko et. al., 2016).

\section{Заключение}

Полученные экспериментальные данные аргументируют вывод о том, что костные остатки неоплейстоценовых медведей и львов из пещеры Иманай принципиально отличаются практически по всем минералогогеохимическим свойствам от аналогичных по возрасту костных остатков, фоссилизированных во внепещерных обстановках.

Иманайский пещерный костный детрит в целом обнаруживает гораздо большую степень вторичных изменений, чем внепещерные костные остатки, что наиболее наглядно выражается в коллофанизации биоапатита и в деградации наноструктуры костей. При этом пещерные кости многократно уступают внепещерным по содержанию иллювиированных в кости минеральных загрязнений.

Типоморфным признаком пещерных костей является их интенсивная эпигенетическая кальцитизация, т. е. замещение первичного биоапатита вторичными карбонатами. Это выражается в 3-5 раз большем содержании $\mathrm{CO}_{2}$ в костях и в аномально высоких значениях атомного отношения $\mathrm{Ca} / \mathrm{P}$, что совершенно не свойственно внепещерному костному детриту. Факт кальцитизации пещерных костей коррелируется с фосфатизацией вмещающих кости грунтов, что объясняется выносом в последние замещенного в костях фосфатного вещества.

В составе исследуемых пещерных костей обнаружены 50 микроэлементов, в том числе элементы-эссенциалы (доля в балансе элементов 25-45 \%), физиологически-активные элементы (60-72 \%) и элементы-антибионты (0-5 \%). Валовая концентрация микроэлементов в иманайских костях в 2-3 раза уступает концентрации микроэлементов во внепещерных костях. Отношение суммарных содержаний элементов-эссенциалов и антибионтов колеблется в пределах 17-158, что гораздо ближе к живым организмам, чем к ископаемым костям, фоссилизированным во внепещерных условиях. Кроме того, пещерные кости кардинально отличаются от вне- 
пещерных по всем геохимическим модулям. Все эти геохимические различия обусловлены аномально низким содержанием в пещерных костях микроэлементов, имеющих источник в костеносных грунтах. Таким образом, фоссилизация костей в пещерных условиях принципиально отличается от таковой во внепещерных обстановках крайне низкой степенью эпигенетического обогащения микроэлементами за счет вмещающей геологической среды.

Значения рентгеновского индекса кристалличности биоапатита в костях львов и медведей в среднем близки к аналогичным данным, полученным для внепещерных костей, но в 1.5 раза уступают по зубам и клыкам. ИК спектроскопический индекс $\mathrm{Iv}_{3}\left[\mathrm{PO}_{4}\right]$ $/ \mathrm{Iv}_{3}\left[\mathrm{CO}_{3}\right]$ биоапатита в иманайских костях варьируется в пределах 1.36-3.51, что в среднем на 35-40 \% ниже, чем для внепещерных костей. Это коррелируется с фактом значительной кальцитизации пещерных костных остатков.

Иманайские пещерные кости характеризуются на порядок меньшим содержанием $\mathrm{C}_{\text {орг }}$ по сравнению с живыми костями и в 1.5-6 раз меньшим по сравнению с внепещерным костным детритом. Выход коллагена из исследованных костных образцов варьируется от 0.5 до 11 вес. \%. По составу примесей он различается: львиный костный коллаген в отличие от медвежьего содержит примесь $\mathrm{Cu}$ и $\mathrm{Zn}$, но не содержит примеси Ті и Мn. Кроме того, в львином коллагене в два раза меньше железа, в три раза меньше калия и в 6-7 раз меньше хлора. По атомному отношению $\mathrm{C} / \mathrm{N}$ (3.47-3.87) полученный из костей коллаген находится на уровне, вполне приемлемом для изотопных исследований.

По углероду и кислороду в биоапатите костный детрит иманайских пешерных львов и медведей является изотопно аномально тяжелым, сближаясь с изотопным составом углерода и кислорода в морских известняках. Как показали наши и зарубежные исследования, такая изотопия биоапатита является типоморфным признаком пещерных ориктоценозов, будучи обусловленной эпигенетической кальцитизацией под воздействием углекислотных вод, образующихся в карстующихся карбонатных породах.
Изотопные данные, полученные по коллагену, свидетельствуют об обитании иманайских пещерных львов и медведей в условиях ландшафтов, переходных от лесов к лесостепям с преобладанием расте-

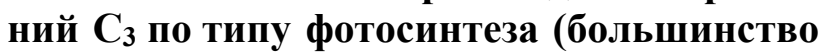
растений в зоне прохладного и умеренно влажного климата). Результат расчета трофической цепи с использованием изотопных данных по коллагеновому углероду и азоту позволяет предположить, что вероятной пищевой жертвой иманайских пещерных львов в отличие от западно-европейских были не пещерные медведи, а шерстистые носороги.

Сравнительный анализ полученных данных показывает, что при всей общей специфичности костные остатки иманайских львов и медведей по многим свойствам не совпадают. Они статистически расходятся по размерам: обломки скелета львов в среднем почти в три раза крупнее, чем обломки скелета медведей. Львиные и медвежьи кости существенно различаются по химическому и нормативноминеральному составу иллювиированных минеральных загрязнений, а также по валовому содержанию микроэлементов. Эти кости демонстрируют несколько разную степень измененности физических свойств: в львиных костях биоапатит сильнее коллофанизирован, а медвежьи кости отличаются большей степенью деградации наноструктуры. Кости львов карбонизированы на 15-20 \% значительнее, чем кости медведей, и различаются по парагенезисам микроминералов-примесей: в львиных костях установлены оксиды, кислородные соли (фосфаты) и силикаты, а в костях медведей выявлена гораздо более широкая ассоциация микроминералов - самородные металлы и сплавы, оксиды, кислородные соли (карбонатсульфаты), силикаты, алюмосиликаты, титаносиликаты. Собственно биоапатит в иманайских костях кристаллохимически тоже нетождественен как в катионной, так и анионной подрешетках. Для львиных костей характерны примеси $\mathrm{Zn}$ и $\mathrm{Fe}$, а для медвежьих - $\mathrm{Sr}$ и $\mathrm{S}$.

Проведенные исследования выявили и некоторые анатомические различия фоссилизации пещерных костей. Так, в направлении от зубов к костям скелета снижается 
индекс кристалличности биоапатита, но увеличиваются интенсивность кальцитизации, степень деградация наноструктуры и валовая концентрация микроэлементов.

Совместное нахождение разновозрастного и в разной степени фоссилизированного костного детрита в элювиальных грунтах пещеры Иманай представляет собой очевидный спелеопалеонтологический парадокс. Объяснение этого парадокса может состоять в более молодом, чем кости, возрасте костеносных грунтов, в которых костные остатки переотлагались с перемешиванием. Исходя из климатической истории конца плейстоцена-начала голоцена можно предположить, что упомянутые грунты, будучи результатом растворения карстующихся известняков, образовались не раньше 15-10 тыс. лет назад. Если принять такую гипотезу, то следует допустить и то, что до захоронения в элювиальных грунтах костные остатки львов и медведей в течение соответственно 32-28 и 25-20 тыс. лет назад подвергались фоссилизации в особых условиях внутрипещерной атмосферы и капельной углекислотной гидросферы. Время такой фоссилизации можно определить как этап спелеовыветривания, который позже сменился этапом фоссилизации в грунтах (рис. 25).

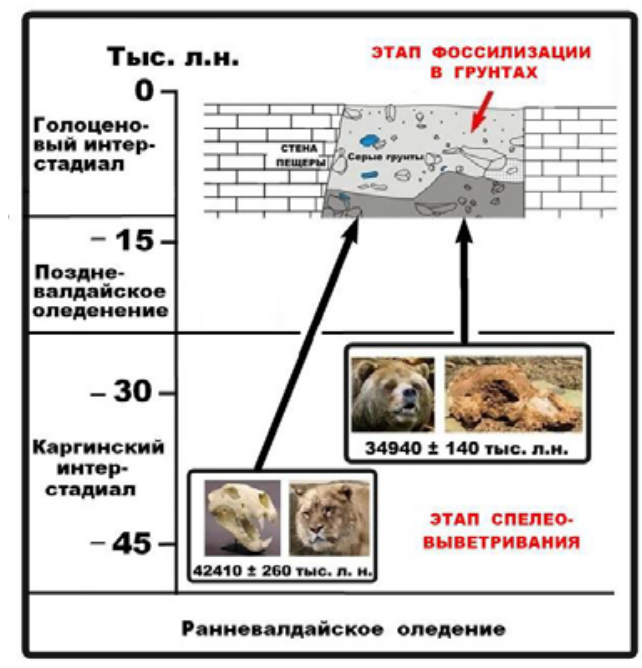

Рис. 25. Схема хронологии и этапности пещуерной фоссилизации костных остатков плейстоценновых млекопитающих на примере пещчеры Иманай
Именно разная продолжительность (на 78 тыс. лет) этапа спелеовыветривания костных остатков львов и медведей и послужила, вероятно, причиной существенного и системного расхождения их минералогогеохимических свойств.

tбнаруженные в пещерно-элювиальных грунтах каменные артефакты среднего палеолита и частицы древесного угля в базальном горизонте осадочного профиля свидетельствуют об обитании в пещере Иманай поздних неандертальцев далеко за пределами традиционного ареала их распространения на территории Западной Европы и Южной Евразии. Это отражает начавшуюся примерно 50-40 тыс. лет назад миграцию неандертальцев на север, в ходе которой они к концу среднего валдая достигли, по крайней мере в европейской части современной России, Полярного круга.

За аналитическое обеспечение авторы благодарят ведущего инженера, к. г.-м. н. Е.А. Васильева (Санкт-Петербургский горный университет), руководителя лабораторией химии минерального сырья О.В. Кокшарову (ИГ Коми НЦ УрО РАН), с. н. с., к. г.-м. н. Ю.С. Симакову и Ю.В. Глухова (ИГ Коми НЦ УрО РАН), старшего физика М.Ф. Самотолкову, химиков-аналитиков С.Т. Неверова (ИГ Коми НЦ УрО РАН) и Е.А Туманову (ИБ Коми НЦ УрО РАН). Выражают также признательность д. и. н. П.Ю. Павлову (ИЯЛИ Коми НЦ УрО РАН) и к. г.- м. н. Д.В. Пономареву (ИГ Коми НЦ УрО РАН) за ценное научное консультирование.

\section{Библиографический список}

Амирханов Х.А., Бронникова М.А., Таймазов A.И. О следах огня на стоянке олдована Айникаб 1 в Центральном Дагестане // Древнейший Кавказ: перекресток Европы и Азии / ИИМК РАН. СПб., 2013. С. 7-19.

Вишняцикий Л. Неандертальцы: история несостоявшегося человечества. СПб.: Нестор-История, 2010. 312 с.

Войнар A.O. Биологическая роль микроэлементов в организме животных и человека. М.: Высшая школа, 1960. 541 с.

Вотяков С.Л., Киселёва Д.В., Щапова Ю.В., Смирнов Н.Г., Садыкова Н.О. Физикохимические характеристики ископаемых костных остатков млекопитающих и проблема их относительного возраста. Ч. 2. ИК и радиоспектро- 
скопия. Екатеринбург: Изд-во «Гощицкий», 2009. $82 \mathrm{c}$.

Гимранов Д.О., Косиниев П.А., Нурмухаметов И.М., Некрасов А.Е. Первая находка дикообраза (Hystrix sp.) и кабана (Sus scrofa) в позднем плейстоцене Южного Урала // Фундаментальные проблемы квартера: Итоги изучения и основные направления исследований: матер. Х Всерос. совещания по изучению четвертичного периода. М.: Геос, 2017. С. 89.

Гимранов Д.О., Котов В.Г., Румянцев М.М., Яковлев А.Г., Сотникова М.В., Нурмухаметов И.М., Сатаев Р.М., Косиниев П.А. Пещера Иманай - новое палеонтологическое и археологическое местонахождение на Южном Урале // 100летие Палеонтологического общества России. Проблемы и перспективы палеонтологических исследований: матер. 62-й сессии Палеонтологического общества при РАН / ВСЕГЕИ. СПб., 2016. C. 231-233.

Гимранов Д.О., Котов В.Г., Румянцев М.М., Силаев В.И., Яковлев А.Г., Яковлева Т.И., Зеленков Н.В., Сотникова М.В., Девяшин М.М., Пластеева Н.А., Зареикая Н.Е., Нурмухаметов И.М., Смирнов Н.Г., Косинцев П.А. Крупнейшее в Евразии захоронение ископаемых львов (Carnivora, Filidae, Pantera (Leo) ex gr. fossilisspelaea) // Доклады РАН. 2018. Т. 482, № 2. С. 234-237.

Горбунова К.А. Из истории отечественной спелеологии (XVIII век) // Пещеры. 1988. Вып. 21. С. 96-104.

Дублянский В.Н., Козлова И.А. К истории изучения пещер Крыма // Известия Крымского краеведческого музея. Симферополь, 1994. № 8. С. 7 14.

Иванова В.В., Никольский П.А. О методе стратиграфической привязки фаунистических остатков на основе фракционирования редкоземельных элементов (на примере плейстоцена Северной Якутии) // Фундаментальные проблемы квартера, итоги изучения и основные направления дальнейших исследований: матер. IX Bсерос. совещания по изучению четвертичного периода. Иркутск: Изд-во Института географии им. В. Б. Сочавы CO РАН, 2015. С. 184-185.

Кокин А.В., Силаев В.И. О соответствии распределения микроэлементов в составе современных бактерий закону периодичности космогеохимической распространенности химических элементов // Вестник геонаук. 2020. № 7. С. 3-8.

Кольфсхотен Т., Маркова А.К., Симакова А.Н., Пузаченко А.Ю. Экосистемы максимального похолодания последнего оледенения (LGM) 24-17 тыс. л. н. // Эволюция экосистем Европы при переходе от плейстоцена к голоцену (24-18 тыс. л. н). М.: Тов. науч. изд-во КМК, 2008. С. 459-465.

Кулешов В.Н., Гаврилов Ю.О. Изотопный состав $\left(\delta^{13} \mathrm{C}, \delta^{18} \mathrm{O}\right)$ карбонатных конкреций из терригенных отложений Северного Кавказа // Литология и полезные ископаемые. 2001. № 2. С. 187190.

Оводов Н.Д. Итог 50-летних палеофаунистических исследований пещер Сибири // Пещеры: охрана, история, современное состояние и перспективы научных исследований в пещерах на территории бывшего СССР // Матер. научнопракт. конф. Красноярск, 2009. С. 54-65.

Париукова М.H. Львино-медвежья пещера Иманай: раскопки костного детрита плейстоценовых млекопитающих // Геолого-археологические исследования в Тимано-Североуральском регионе: доклады 19-й научной конференции. Сыктывкар: Геопринт, 2016. Т. 19. С. 77-81.

Силаев В.И., Лютоев В.П., Петровский В.А., Хазов А.Ф. Опыт исследований природных углеродистых веществ и некоторых их синтетических аналогов методом рамановской спектроскопии // Минералогический журнал. 2013. Т. 35, № 3. С. 33-47.

Силаев В.И., Пономарев Д.В., Симакова Ю.С., Шанина С.Н., Смолева И.В., Тропников Е.М., Хазов $А$. $\Phi$. Современные исследования ископаемого костного детрита: палеонтология, минералогия, геохимия // Вестник ИГ Коми НЦ УрО РАН. 2016. № 5. C. 19-31.

Силаев В.И., Симакова Ю.С., Паршукова М.Н., Гимранов Д.О. Костеносные элювиальные грунты в Иманайской пещере на Южном Урале // Проблемы минералогии, петрографии и металлогении. Научные чтения памяти П. Н. Чирвинского: сб. статей / Перм. гос. ун-т. Пермь, 2018. Вып. 21. С. $168-184$.

Силаев В.И., Пономарев Д.В., Слепченко С.М., Бондарев А.А., Киселёва Д.В., Смолева И.В.,

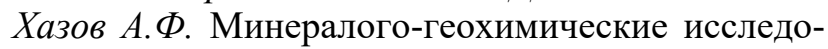
вания костного детрита плейстоценовых млекопитающих, включая древнейшего в Северной Евразии сапиенса // Вестник Пермского университета. Геология, 2015. Вып. 5 (30). С. 3-27.

Силаев В.И., Слепченко С.М., Бондарев А.А., Смолева И.В., Киселёва Д.В., Шанина С.Н., Мартиросян О.В., Тропников Е.М., Хазов А.Ф. Усть-ишимская кость: минералого-геохимическая свойства как источник палеонтологической, палеоантропологической и палеоэкологической информации // Вестник Пермского университета. Геология. 2017. Вып. 1 (34). С. 6-30.

Силаев В.И., Шанина С.Н., Смолева И.В., Киселёва Д.В., Чередниченко Н.В., Хазов А.Ф., Туманова Е.А., Павлов П.Ю. Опыт использования 
минералого-геохимических свойств костных остатков для реконструкции среды обитания на палеолитической стоянке Заозерье (Средний Урал) // ПАЖМИ. 2019. № 2. С. 35-77.

Смирнов Н.Г., Вотяков С.Л., Садыкова Н.О., Киселёва Д.В., Щапова Ю.В. Физико-химические характеристики ископаемых костных остатков млекопитающих и проблема их относительного возраста. Ч. 1. Термический и масс-спектрометрический анализы. Екатеринбург: Изд-во «Гощицкий», 2009. 118 с.

Сотникова М.В., Гимранов В.О. О находках гигантских львов в мустьерских слоях (поздний плейстоцен) пещеры Иманай (Южный Урал) // Интергративная палеонтология: перспективы развития для геологических целей: матер. LXIII сессии Палеонтологического общества при РАН / ВСЕГЕИ. СПб., 2017. С. 207-208.

Сотникова М.В., Кириллова И.В. Крупный представитель семейства Felidae Pantera (Leo) ex. gr. Fossilis-spelaea из черноярского аллювия на нижней Волге (Россия) // Фундаментальные проблемы квартера: итоги изучения и основные направления дальнейших исследований: матер. X Всерос. совещания по изучению четвертичного периода. М.: ГЕОС, 2017. С. 317-318.

Формозов А.А. Из записей о первобытном обществе // ПАЖМИ. 2019. № 1. С. 10-47.

Чикищев А.Г. Пещеры на территории СССР. М.: Наука, 1973. 136 с.

Яковлев А.Г., Яковлева Т.И., Гимранов Д.О. Мелкие позвоночные (земноводные, пресмыкающиеся и млекопитающие) из местонахождения Иманай-1 (Южный Урал) // Геология, полезные ископаемые и проблемы геоэкологии Башкортостана, Урала и сопредельных территорий: матер. и доклады 11-й межрегион. науч.-практ. конф., посвященной 65-летию Института геологии УНЦ PAН. Уфа, 2016. C. 81-82.

Ambrose S.H. Preparation and characterization of bone and tooth collagen for isotopic analysis // J. of Archaeolog. Science. 1990. Vol. 17. P. 431-451.

Argani A., Jeannet M., Argaht J., Erlajeva M. The big cats of the fossil site Chateau Brecccia Northern Section (Saone-et-Loire, Burgundy, France): stratigraphy, palaeoenvironment, ethology and biochronological dating // Courier Forschunginstitute Senckenberg. 2007. Vol. 259. P. 121-140.

Barycka E. Middle and Late Pleistocene Felidae and Hyaenidae of Poland // Faune Poloniae New Series. 2008. Vol. 2. 228 p.

Bocherens $H$. Isotopic insights on cave bear palaeodiet // Historal biology. 2019. Vol. 31, № 4. P. 410-421.

Bocherens H., Drucker D. Trophic level isotopic enrichments for carbon and hitrogen in collagen: case Studies from carbon and ancient terrestrial ecosystems // International J. of Osteoarchaeology. 2003. Vol. 13. P. 46-53.

Bocherens H., Drucker D.G., Bominigue B., Bridault A., Conard N.J., Cupillard Ch., Germonpre M., Honeisen M., Munzel S.C., Napierala H., PatouMathis M., Stephan E., Uerpmann H.-P., Ziegler R. Isotopic evidence for dietary ecology of cave (Pantera spelaea) in North-Western Europe: Prey Choise competition and implications for extinction // Quaternary International. 2011. Vol. 246. P. 249-261.

De Niro M. J. Postmortem pereservation and alternation of in-vivo bone collagen isotope rations in relation to palaeodietary reconstruction // Nature. 1985. Vol. 317. P. 806-809.

Gimranov D., Kosintsev P. Quaternary large mammals from the Imanay Cave // Quaternary International. 2020 (Article in print).

Gimranov D.O., Kotov V.G., Rumyanzev M.M., Silaev V.I., Yakovlev A.G., Yakovleva T.I., Zelenrov N.V., Sotnikova M.V., Devyashin M.M., Plasteeva N.A., Zarezkaya N.E., Nurmuhametov N.M., Smirnov N. G., Kosintsev P.A. The Largest in Eurasia Bulking of mineral lives (Carnivora, Felidae, Panthera (Leo) ex gr. Fossilis-spelaea) // Doklady Biological Science. 2018. Vol. 482. No. 1. P. 191-193.

Guthrie R.D. Paleoecology of the large mammal community in interion Alaska during the late Pleustocene // Am. Midland Naturalist. 1968. Vol.79. P. 346-363.

Herwartz D., Tutken T., Jochum K. P., Sander P. M. 2013. Rare earth elements systematics of fossil bone revealed by LA-ISP-MS analysis // Geochimica et Cosmochimica Acta. 2013. Vol. 103. P. 161-183.

Hublin J.-J., Sirakov N., Aldeias $V$. et al. Iwitial Upper Palaeolithic Homo sapiens from Bacho Kiro Cave, Bulgaria // Natura. 2020. URL: htts: // doi.org/ $10.1038 / \mathrm{s} 4158.6-020-2259-\mathrm{z}$

James S.R. Hominid Use of Fire in the Lower and Middle Pleistocene: A Review of the Evidence // Current Anthropology (University of Chicago Press). 1989. Vol. 30. No. 1. P. 1-26.

Lindahl T.R. Fossiln DNA // Current Biology. 2000. Vol. 10 (17). Doi: 10.1016/50960-9822 (00) 00668-0.

Mc Lennan S.M. Rare earth element geochemistry and the «tetrad» effect // Geochim. Cosmochim. Acta. 1994. Vol. 58. P. 2025-2033.

Pitulko V.V., Tikhonov A.N., Pavlova E.Y., Nikolsky P.A., Kuper K.E., Polozov R.N. Early human presence in the Arctic evidence from 45000-year-old mammoth remains // Science. 15 Januar 2016. Vol. 351. № 6270. P. 260-263.

Silaev V.I., Ponomarev D.V., Kiseleva D.V., Smoleva I.V., Simakova Yu.S., Martirosyan O.V., 
Vasiliev E.A., Khazov A.F., Tropnikov E.M. Mineralogical-geochemical Characteristic of the Bone Detritus of Pleistocene Mammals as a Source of Paleontological Information // Paleontogical Journal. 2017. Vol. 51. No. 13. P. 1395-1421.

Slimak L., Svendson J.I., Mangerud J., Plisson H., Heggen H. P., Brugere A., Pavlov P. Yu. Late Mousterian Persistence near the Arctic Circle // Science. 2011. Vol. 332. P. 841-844.
Stuart A.J., Lister A.M. Extinction chronology of the cave lion Panthera spelaea // Quaternary Science Reviews. 2011. Vol. 30. P. 2329-2340.

Turner $A$. The evolution of the guild of large carnivore of the middle and late Pleistocene // J. Quarternary Science Reviews. 2009. Vol. 4. P. 991-1005.

Tutken T., Furrer H., Venntmann T.W. Stable isotope compositions of mammoth teeth from Niedorweningen, Switzerland; Implications for the Late Pleistocene climate, environ and diet // Quateruary International. 2007. Vol. 164-165. P. 139-150.

\title{
Mineralogical and Geochemical Features of Cave Fossilization of Bone Detritus on the Example of Ima- nay Cave (South Urals)
}

\section{V.I. Silaeva, M.N. Parshukova ${ }^{\mathrm{b}}$, D.O. Gimranov ${ }^{\mathrm{c}}$, V.N. Filippov ${ }^{\mathrm{a}}$, D.V. Kiseleva ${ }^{\mathrm{d}}$,} I.V. Smoleva ${ }^{a}$, E.M. Tropnikov ${ }^{a}$, A.F. Khazova

${ }^{a}$ Institute of Geology Komi SC Ural Branch, Russian Academy of Sciences

54 Pervomayskaya Str., Syktyvkar 167982, Russia. E-mail: silaev@geo.komisc.ru

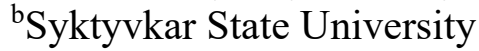

55 Oktyabrsky Ave., Syktyvkar 167000, Russia

${ }^{\mathrm{c}}$ Institute of Plant and Animal Ecology Ural Branch of the Russian Academy of Sciences

8 March Str., Bld. 202, Yekaterinburg 620144, Russia

dinstitute of Geology and Geochemistry Ural Branch of the Russian Academy of Sciences

15 Academician Vonsovsky Str., Yekaterinburg 620016, Russia

\begin{abstract}
First time, the results of complex mineralogical and geochemical studies of fossil bone detritus of Pleistocene mammals from the Imanay Cave (South Urals) were obtained using optical and scanning electron microscopy, a statistical volumetric method for nanoporosity determination, thermal, X-ray structural and X-ray fluorescence analyzes, gas chromatography, IR, Raman and x-ray luminescent spectroscopy, ICP MS, and isotope mass spectrometry. The aim of the research was to obtain experimental data on the nature and degree of fossilization of bone remains in caves, and to assess the possibilities of paleoecological reconstructions from cave fossil bones. The data on the microstructure of bone remains, nanoporosity, chemical composition and concentration of trace elements, X-ray structural and thermal properties, isotopic composition of the mineral, and organic components in bones are discussed. According to the data obtained, fossilization of bone remains in caves is fundamentally different at all levels of structure and composition of fossil bones from those outside caves environments. In particular, cave bones are distinguished by intense epigenetic calcitization, $3-5$ times higher $\mathrm{CO}_{2}$ content and abnormally high $\mathrm{Ca} / \mathrm{P}$ atomic ratios, but they are many times inferior in terms of the content of illuminated mineral impurities, enrichment in microelements of the host geological environment, content of $\mathrm{C}_{\text {org }}$ and collagen. According to the isotopic composition of carbon and oxygen in bioapatite, cave bone detritus is abnormally heavy, approaching the isotopic composition of carbon and oxygen in marine limestones. Some paleoecological reconstructions are presented and evidence of the habitation of the late Neanderthals in the Imanai cave is considered. Key words: Neopleistocene; South Urals; Imanay cave; cave lions and bears; mineralogical and geochemical studies; peculiarities of cave fossilization of fossil bones; paleoecological reconstructions; late Neanderthals.
\end{abstract}

\section{References}

Amirkhanov Kh.A., Bronnikova M.A., Taymazov A.I. 2013. O sledakh ognya na stoyanke oldovana Aynikab $1 \mathrm{v}$ Tsentralnom Dagestane [About traces of fire at the site Oldovan Ainikab 1 in Central Dagestan]. In: Ancient Caucasus: the crossroads of Europe and Asia. SPb: IHMC RAN, 2013. pp. 7-19. (in Russian)
Vishnyatskiy L. 2010. Neandertaltsy: istoriya nesostoyavshegosya chelovechestva (Neanderthals: History of Failed Humanity). SPb: Nestor-History, p. 312. (in Russian)

Voynar A.O. 1960. Biologicheskaya rol mikroelementov v organizme zhivotnykh i cheloveka (Biological role of microelements in the body of animals and humans). Moscow: Higher school, p. 541. (in Russian) 
Votyakov S.L., Kiseleva D.V., Shchapova Yu.V., Smirnov N.G., Sadykova N.O. 2009. Fizikokhimicheskiye kharakteristiki iskopayemykh kostnykh ostatkov mlekopitayushchikh i problema ikh otnositelnogo vozrasta. Chast 2 . IK- i radiospektroskopiya. [Physical and chemical characteristics of fossil mammalian bone remains and the problem of their relative age. Part 2. IR and radio spectroscopy]. Yekaterinburg: Goschitsky, p. 82. (in Russian)

Gimranov D.O., Kosintsev P.A., Nurmukhametov I.M., Nekrasov A.E. 2017. Pervaya nakhodka dikoobraza (Hystrix sp.) i kabana (Sus scrofa) v pozdnem pleystotsene Yuzhnogo Urala [First discovery of a porcupine (Hystrix $s p$.) and a wild boar (Sus scrofa) in the late Pleistocene of the southern Urals]. In: Fundamental problems of the Quarternary: Results of the study and main directions of research. Moscow: GEOS, p. 89. (in Russian)

Gimranov D.O., Kotov V.G., Rumyantsev M.M., Yakovlev A.G., Sotnikova M.V., Nurmukhametov I.M., Sataev R.M., Kosintsev P.A. 2016. Peshchera Imanay - novoye paleontologicheskoye i arkheologicheskoye mestonakhozhdeniye na Yuzhnom Urale [Imanay Cave - a new paleontological and archaeological location in the southern Urals]. In: $100^{\text {th }}$ anniversary of the paleontological society of Russia. Problems and prospects of paleontological research: Proceedings of the 62nd session of the Paleontological society of the Russian Academy of Sciences. Saint Petersburg: VSEGEI Publishing, pp. 231-233. (in Russian)

Gimranov D.O., Kotov V.G., Rumyantsev M.M., Silaev V.I., Yakovlev A.G., Yakovleva T.I., Zelenkov N.V., Sotnikova M.V., Devyashin M.M., Plasteeva N.A., Zaretskaya N.E., Nurmukhametov I.M., Smirnov N.G., Kosintsev P.A. 2018. Krupneysheye v Yevrazii zakhoroneniye iskopayemykh lvov (Carnivora, Filidae, Pantera (Leo) ex gr. fossilisspelaea) [The largest burial of fossil lions in Eurasia (Carnivora, Filidae, Pantera (Leo) ex gr. fossilis-spelaea)]. Reports of the Russian Academy of Sciences, 482(2):234-237. (in Russian)

Gorbunova K.A. 1988. Iz istorii otechestvennoy speleologii (XVIII vek) [From the history of Russian speleology (XVIII century)]. Caves. 21:96-104. (in Russian)

Dublyanskiy V.N., Kozlova I.A. 1994. K istorii izucheniya peshcher Kryma [To the history of the study of the caves of the Crimea]. Proceedings of the Crimean Museum of Local Lore. 8:7-14. (in Russian)

Ivanova V.V., Nikolsky P.A. 2015. O metode stratigraficheskoy privyazki faunisticheskikh ostatkov na osnove fraktsionirovaniya redkozemel-nykh elementov (na primere pleystotsena Severnoy Yakutii) [On the method of stratigraphic binding of faunal remains based on the fractionation of rare earth elements (on the example of the Pleistocene of Northern Yakutia)]. In: Fundamental problems of the Quaternary, the results of the study and the main directions of further research: Materials of the IX all-Russian meeting on the study of the Quaternary period. Irkutsk: publishing of Institute of geography of the SB RAS, pp. 184-185. (in Russian)

Kokin A.V., Silaev V.I. 2020. O sootvetstvii raspredeleniya mikroelementov v sostave sovremennykh bakteriy zakonu periodichnosti kosmogeokhimicheskoy rasprostranennosti khimi-cheskikh elementov [On the accordance of the distribution of trace elements in the composition of modern bacteria to the law of periodicity of cosmogeochemical distribution of chemical elements]. Bulletin of Geosciences. 7:3-8. (in Russian)

Kolfschoten T., Markova A.K., Simakova A.N., Puzachenko A.Yu. 2008. Ekosistemy maksimalnogo pokholodaniya poslednego oledeneniya (LGM) 2417 tys. In [Ecosystems of maximum cooling of the last glaciation (LGM) 24-17 kyr BP]. In: Evolution of European ecosystems during the transition from the Pleistocene to the Holocene (24-18 kyr BP). Scientific publishing house of KMK, pp. 459465. (in Russian)

Kuleshov V.N., Gavrilov Yu.O. 2001. Izotopnyy sostav $\left(\delta^{13} \mathrm{C}, \delta{ }^{18} \mathrm{O}\right)$ karbonatnykh konkretsiy iz terrigennykh otlozheniy Severnogo Kavkaza [Isotopic composition $\left(\delta^{13} \mathrm{C}, \delta^{18} \mathrm{O}\right)$ of carbonate nodules from terrigenous deposits of the North Caucasus]. Lithology and useful fossils. 2:187-190. (in Russian)

Ovodov N.D. 2009. Itog 50-letnikh paleofaunisticheskikh issledovaniy peshcher Sibiri [The result of 50 years of paleofauna research of Siberian caves]. In: Caves: protection, history, current state and prospects of scientific research in caves in the territory of the former USSR. Materials of the scientific-practical conference. Krasnoyarsk, pp. 54-65. (in Russian)

Parshukova M.N. 2016. Lvino-medvezhya peshchera Imanay: raskopki kostnogo detrita pleystotsenovykh mlekopitayushchikh [Lion-bear cave Imanay: excavations of bone detritus of Pleistocene mammals]. In: Geological and archaeological research in the Timan-North Urals region. Reports of the 19th scientific conference. Syktyvkar. Geoprint. 19:77-81. (in Russian)

Silaev V.I., Lyutoev V.P., Petrovskiy V.A., Khazov A.F. 2013. Opyt issledovaniy prirodnykh uglerodistykh veshchestv i nekotorykh ikh sinteticheskikh analogov metodom ramanovskoy spektroskopii [Experience of studying the natural carbonaceous substances and some of their synthetic analogs by the method of Raman spectroscopy]. Mineralogical journal. 35(3):33-47. (in Russian) 
Silaev V.I., Ponomarev D.V., Simakova Yu.S., Shanina S.N., Smoleva I.V., Tropnikov E.M., Khazov A.F. 2016. Sovremennyye issledovaniya iskopaemogo kostnogo detrita: paleontologiya, mineralogiya, geokhimiya [Modern studies of fossil bone detritus: paleontology, mineralogy, geochemistry]. Bulletin of the Institute of Geology, Komi science center UB RAS. 5:19-31. (in Russian)

Silaev V.I., Simakova Yu.S., Parshukova M.N., Gimranov D.O. 2018. Kostenosnye elyuvialnye grunty v Imanayskoy peshchere na Yuzhnom Urale [Bone-Bearing eluvial soils in the Imanay cave in the southern Urals]. In: Problems of mineralogy, petrography and metallogeny: Materials of scientific readings in memory of $P$. N. Chirvinsky. Issue 21. Perm: Perm University Publishing House, pp. 168-184. (in Russian)

Silaev V.I., Ponomarev D.V., Slepchenko S.M., Bondarev A.A., Kiseleva D.V., Smoleva I.V., Khazov A.F. 2015. Mineralogo-geokhimicheskiye issledovaniya kostnogo detrita pleystotsenovykh mlekopitayushchikh, vklyuchaya drevneyshego v Severnoy Yevrazii sapiyensa [Mineralogical and geochemical studies of bone detritus of pleistocene mammals, including the earliest in northern Eurasia humans]. Vestnik Permskogo universiteta. Geologiya, 4(29):631. (in Russian)

Silaev V.I., Slepchenko S.M., Bondarev A.A., Smoleva I.V., Kiseleva D.V., Shanina S.N., Martirosyan O.V., Tropnikov E.M., Khazov A.F. 2017. UstIshimskaya kost: mineralogo-geokhimicheskie svoystva kak istochnik paleontologicheskoy, paleoantropologicheskoy i paleoekologicheskoy informatsii [Ust-Ishimsk bone: mineralogical and geochemical properties as a source of paleontological, paleoanthropological and paleoecological information]. Vestnik Permskogo universiteta. Geologiya. 16(1): 1-25. (in Russian)

Silaev V.I., Shanina S.N., Smoleva I.V., Kiseleva D.V., Cherednichenko N.V., Khazov A.F., Tumanova E.A., Pavlov P.Yu. 2019. Opyt ispolzo-vaniya mineralogo-geokhimicheskikh svoy-stv kost-nykh ostatkov dlya rekonstruktsii sredy obitaniya na paleoliticheskoy stoyanke Zaozerye (Sredniy Ural) [Experience of using the mineral and geochemical properties of bone remains for the reconstruction of the habitat at the Zaozerye Paleolithic site (Middle Urals)]. PAJIS. 2:35-77. (in Russian)

Smirnov N.G., Votyakov S.L., Sadykova N.O., Kiseleva D.V., Shchapova Yu.V. 2009. Fizikokhimicheskiye kharakteristiki iskopayemykh kostnykh ostatkov mlekopitayushchikh i problema ikh otnositelnogo vozrasta. Chast 1. Termicheskiy i mass-spektrometricheskiy analizy [Physical and chemical characteristics of fossil mammalian bone remains and the problem of their relative age. Part
1. Thermal and mass spectrometric analyses]. Yekaterinburg. Goschitsky, p. 118. (in Russian)

Sotnikova M.V., Gimranov V.O. 2017. O nakhodkakh gigantskikh lvov v mustyerskikh sloyakh (pozdniy pleystotsen) peshchery Imanay (Yuzhnyy Ural) [About the findings of giant lions in the Mousterian layers (Late Pleistocene) of the Imanay Cave (Southern Urals)]. In: Intergrative paleontology: prospects of development for geological purposes. Proceedings of the LXIII session of the Paleontological society of the Russian Academy of Sciences. Saint Petersburg: VSEGEI, pp. 207-208. (in Russian)

Sotnikova M.V., Kirillova I.V. 2017. Krupnyi predstavitel semeystva Felidae Pantera (Leo) ex. gr.

Fossilis-spelaea iz chernoyarskogo allyuviya na nizhney Volge (Rossiya) [A large representative of the family Felidae Pantera (Leo) ex. gr. Fossilisspelaea from the chernoyarskiy alluvium on the lower Volga (Russia)]. In: Fundamental problems of the Quaternary: results of study and main directions of further research: Mater. X all-Russian conference on the study of the Quaternary period, Moscow: GEOS, pp. 317-318. (in Russian)

Formozov A.A. 2019. Iz zapisey o pervobytnom obshchestve [From the records of primitive society]. PAJIS. 1:10-47. (in Russian)

Chikishev A. G. Peshchery na territorii SSSR (Caves in the USSR). Moscow: Nauka, 1973. 136 p. (in Russian)

Yakovlev A.G., Yakovleva T.I., Gimranov D.O. 2016. Melkie pozvonochnye (zemnovodnye, presmykayushchiyesya i mlekopitayushchiye) iz mestonakhozhdeniya Imanay-1 (Yuzhnyy Ural) [Small vertebrates (amphibians, reptiles and mammals) from the Imanay-1 site (Southern Urals)]. In: Geology, minerals and problems of Geoecology of Bashkortostan, the Urals and adjacent territories. Ufa, pp. 81-82. (in Russian)

Ambrose S.H. 1990. Preparation and characterization of bone and tooth collagen for isotopic analysis. J. of Archaeolog. Science. 17:431-451.

Argani A., Jeannet M., Argaht J., Erlajeva M. 2007. The big cats of the fossil site Chateau Brecccia Northern Section (Saone-et-Loire, Burgundy, France): stratigraphy, palaeoenvironment, ethology and biochronological dating. Courier Forschunginstitute Senckenberg. 259:121-140.

Barycka E. 2008. Middle and Late Pleistocene Felidae and Hyaenidae of Poland. Faune Poloniae v.2. New Series, p. 228.

Bocherens H. 2019. Isotopic insights on cave bear palaeodiet. Historal biology. 31(4):410-421.

Bocherens H., Drucker D. 2003. Trophic level isotopic enrichments for carbon and nitrogen in collagen: case studies from carbon and ancient terrestri- 
al ecosystems. International J. of Osteoarchaeology. 13:46-53.

Bocherens H., Drucker D.G., Bominigue B., Bridault A., Conard N.J., Cupillard Ch., Germonpre M., Honeisen M., Munzel S.C., Napierala H., PatouMathis M., Stephan E., Uerpmann H.-P., Ziegler R. 2011. Isotopic evidence for dietary ecology of cave (Pantera spelaea) in North-Western Europe: Prey Choise competition and implications for extinction. Quaternary International. 246:249-261.

De Niro M.J. 1985. Postmortem preservation and alternation of in-vivo bone collagen isotope rations in relation to palaeodietary reconstruction. Nature. 317:806-809.

Gimranov D., Kosintsev P. 2020. Quaternary large mammals from the Imanay Cave. Quaternary International (Article in press).

Gimranov D.O., Kotov V.G., Rumyanzev M.M.,Silaev V.I., Yakovlev A.G., Yakovleva T.I., Zelenrov N.V., Sotnikova M.V., Devyashin M.M., Plasteeva N.A., Zarezkaya N.E., Nurmuhametov N.M., Smirnov N.G., Kosintsev P.A. 2018. The Largest in Eurasia Bulking of mineral lives (Carnivora, Felidae, Panthera (Leo) ex gr. Fossilis-spelaea). Doklady Biological Science. 482(1):191-193.

Guthrie R.D. 1968. Paleoecology of the large mammal community in interior Alaska during the late Pleistocene. American Midland Naturalist 79:346-363. doi: $10.2307 / 2423182$

Herwartz D., Tutken T., Jochum K.P., Sander P.M. 2013. Rare earth elements systematics of fossil bone revealed by LA-ISP-MS analysis. Geochimica et Cosmochimica Acta. 103:161-183.

Hublin J.-J., Sirakov N., Aldeias V. et al. Iwitial Upper Palaeolithic Homo sapiens from Bacho Kiro Cave, Bulgaria. Natura, 581:299-302. doi: $10.1038 / \mathrm{s} 4158.6-020-2259-\mathrm{z}$
James S.R. 1989. Hominid Use of Fire in the Lower and Middle Pleistocene: A Review of the Evidence. Current Anthropology. 30(1):1-26.

Lindahl T.R. 2000. Fossil DNA. Current Biology. 10 (17), PR616. doi: 10.1016/50960-9822 (00) 00668-0.

Mc Lennan S.M. 1994. Rare earth element geochemistry and the «tetrad» effect. Geochim. Cosmochim. Acta. 58:2025-2033.

Pitulko V.V., Tikhonov A.N., Pavlova E.Y., Nikolsky P.A., Kuper K.E., Polozov R.N. 2016. Early human presence in the Arctic evidence from 45000year-old mammoth remains. Science. 351(6270):260-263.

Silaev V.I., Ponomarev D.V., Kiseleva D.V., Smoleva I.V., Simakova Yu.S., Martirosyan O.V., Vasiliev E.A., Khazov A.F., Tropnikov E.M. 2017. Mineralogical-geochemical Characteristic of the Bone Detritus of Pleistocene Mammals as a Source of Paleontological Information. Paleontogical Journal. 51(13):1395-1421.

Slimak L., Svendson J.I., Mangerud J., Plisson H., Heggen H.P., Brugere A., Pavlov P.Yu. 2011. Late Mousterian Persistence near the Arctic Circle. Science. 332:841-844.

Stuart A.J., Lister A.M. 2011. Extinction chronology of the cave lion Panthera spelaea. Quaternary Science Reviews. 30:2329-2340.

Turner A. 2009. The evolution of the guild of large carnivore of the middle and late Pleistocene. J. Quarternary Science Reviews. 4:991-1005.

Tutken T., Furrer H., Venntmann T.W. 2007. Stable isotope compositions of mammoth teeth from Niedorweningen, Switzerland; Implications for the Late Pleistocene climate, environ and diet. Quateruary International. 164-165:139-150. 